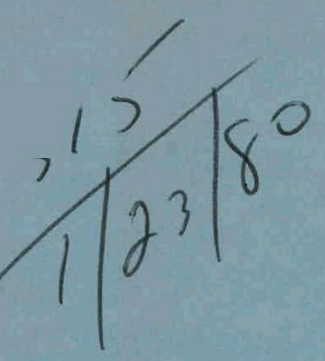

\title{
ANNUAL REPORT FOR 1978 ON RESEARCH, DEVELOPMENT AND DEMONSTRATION OF NICKEL-ZINC BATTERIES FOR ELECTRIC VEHICLE PROPULSION
}

Contract No. 31-109-38-4248

by

Energy Research Corporation

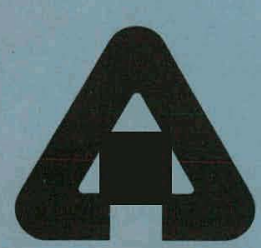

ARGONNE NATIONAL LABORATORY, ARGONNE, ILLINOIS Operated for the U. S. DEPARTMENT OF ENERGY under Contract W-31-109-Eng-38 


\section{DISCLAIMER}

This report was prepared as an account of work sponsored by an agency of the United States Government. Neither the United States Government nor any agency Thereof, nor any of their employees, makes any warranty, express or implied, or assumes any legal liability or responsibility for the accuracy, completeness, or usefulness of any information, apparatus, product, or process disclosed, or represents that its use would not infringe privately owned rights. Reference herein to any specific commercial product, process, or service by trade name, trademark, manufacturer, or otherwise does not necessarily constitute or imply its endorsement, recommendation, or favoring by the United States Government or any agency thereof. The views and opinions of authors expressed herein do not necessarily state or reflect those of the United States Government or any agency thereof. 


\section{DISCLAIMER}

Portions of this document may be illegible in electronic image products. Images are produced from the best available original document. 
The facilities of Argonne National Laboratory are owned by the United States Government. Under the terms of a contract (W-31-109-Eng-38) among the U.S. Department of Energy, Argonne Universities Association and The University of Chicago, the University employs the staff and operates the Laboratory in accordance with policies and programs formulated, approved and reviewed by the Association.

\section{MEMBERS OF ARGONNE UNIVERSITIES ASSOCIATION}

The University of Arizona Carnegie-Mellon University Case Western Reserve University The University of Chicago University of Cincinnati Illinois Institute of Technology Univer sity of Illinois Indiana University

The University of Iowa Iowa State University
The University of Kansas Kansas State University Loyola University of Chicago Marquette University The University of Michigan Michigan State University University of Minnesota Unlversity of Missouri Northwestern University University of Notre Dame
The Ohio State University

Ohio University

The Pennsylvania State University Purdue University

Saint Louis University

Southern Illinois University

The University of Texas at Austin

Washington University

Wayne State University

The University of Wisconsin-Madison

\section{NOTICE}

This report was prepared as an account of work sponsored by the United States Government. Neither the United States nor the United States Department of Energy, nor any of their employees, nor any of their contractors, subcontractors, or their employees, makes any warranty, express or implied, or assumes any legal liability or responsibility for the accuracy, completeness or usefulness of any information, apparatus, product or process disclosed, or represents that its use would not infringe privately-owned rights. Mention of commercial products, their manufacturers, or their suppliers in this publication does notimply or connote approval or disapproval of the product by Argonne National Laboratory or the U. S. Department of Energy.

Printed in the United States of America

Available from

National Technical Information Service Springfield, Virginia 22161

NTIS price codes

Printed copy: A07

Microfiche copy: A01 
Distribution Category:

Energy Storage--ElectrochemicalNearterm Batteries (UC-94ca)

\author{
ANL/OEPM-78-10 \\ Annual Report for 1978 on \\ RESEARCH, DEVELOPMENT AND DEMONSTRATION OF \\ NICKEI ZINC BATTERIES FOR \\ ELECTRIC VEHICLE PROPULSION
}

\author{
Prepared for \\ The Office for Electrochemical Project Management \\ Argonne National Laboratory \\ Under Contract No. 31-109-38-4248
}

\author{
By \\ Energy Research Corporation \\ Danbury, Connecticut
}

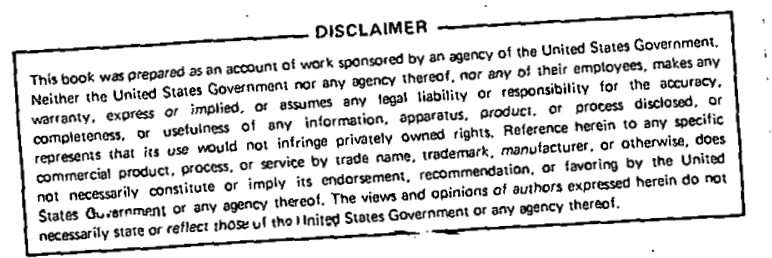

October 1979 


\section{ADDRESS VERIFICATION}

In order that we may verify your address on our distribution list, please detach this form, complete the information requested below, fold as indicated, seal with tape or staple, and place in mail.

Name

Mailing Address

City State Zip

I wish to continue to receive ANL/OEPM reports from near-term electric vehicle battery contractors.

Please return this form even if you do not wish future reports.

If you have returned an identical form to this one in the last 90 days, you need not resubmit another.

Thank You. 
ARGONNE NATIONAL LABORATORY

Office for Electrochemical Project Mgmt.

Building 2.05

9700 South Cass Avenue

Argonne, IL 60439

Attn: Dawn Landis 


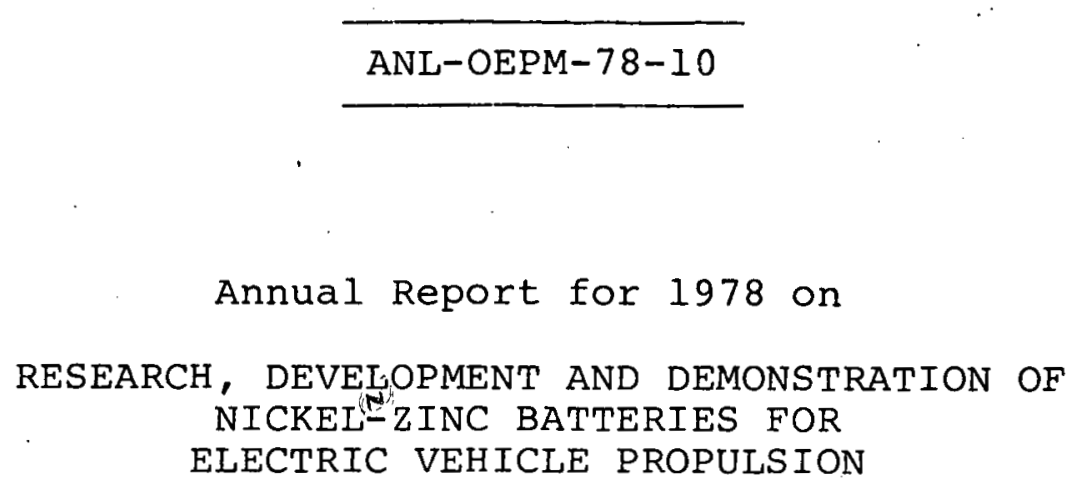

Prepared for

The Office for Electrochemical Project Management Argonne National Laboratory

Under Contract No. 31-109-38-4248

BY

Energy Research Corporation

3 Great Pasture Road

Danbury, Connecticut 06810

June 1979 
Page No.

SECTION I - INTRODUCTION

1

1.0 Introduction. . . 2

SECTION II - NICKEL ELECTRODE DEVELOPMENT FOR 5

NICKEL-ZINC CELLS - TASK I

1.0 Introduction 6

2.0 Technical Discussion 7

3.0 Conclusions 11

SECTION III - ZINC ELECTRODE DEVELOPMENT FOR 13

Ni-Zn CELLS - TASK II

1.0 Introduction 14

2.0 Technical Discussion 15

3.0 Conclusions al

SECTION IV - SEPARATOR DEVELOPMENT FOR Ni-Zn 43

CELLS - TASK III

1.0 Introduction 44

2.0 Technical Discussion . 45

3.0 Conclusions $\quad 69$

SECTION $V$ - DEVELOPMENT OF SEALED NICKEL-ZINC 71 CELLS - TASK IV

1.0 Introduction.

2.0 Technical Discussion 73

3.0 Conclusions 92

SECTION VI - SYSTEM ENGINEERING - TASK V 93

1.0 Introduction 994

2.0 Cell Design, Fabrication and Testing 95

3.0 Charge Control $\quad 115$

4.0 Data Reduction and Cell Modeling 122

5.0 Conclusions $\quad 123$ 


\section{TASK II}

1. Zinc Electrode Arrangement

2 Single Electrode Cell

2A Single Electrode Cell with Split Zinc Electrode 19

3 Cell S3, Zinc Half Electrode Construction 21

4 Single Electrode Cell with Split Silver Electrode 23

5 Silver Electrode Arrangement 24

6 Cell A, IOA Discharge 26

7 Cell B, IOA Discharge 27

8 Cell C, Section Current vs Time 28

9 Cell D, Section Current vs Time 29

10 Cell Sl, 1 Full Positive Electrode, cdo Additive 30

11 Cell S2, 1 Full-Split Positive Electrode, 31 Cdo Additive

12 Cell S2, Sertion Currenl vs 'l'ime 32

13 Cell 53,1 Full-split Positive Electrode, . 33 cdo Additive with Inert conductive Layer nn Collevilirr

14 Cell S3, Section current vs Time

15 Cell S4, I Full-Split Positive Electrode, 36

16 Cell 54 , Section Current vs Time 37

17 Cell S5, 1 Full Positive Electrode cao Additive 38 + TFE

18 Cell s6, Section Current vs Time 39

19 Cell S6, I Full-Split Silver Electrode, Cdo 40 Additive + TFE

TASK TII

1 Pore Distribution Curve of Sample P-64 56

2 Pore Distribution Curve nf Sample P- 50 . 57

3 Distribution or Fores in Separator 58

4 Diffusion Apparatus 59

5 Hydroxyl Ion Diffusion through Various 61

Separators

6 Tensile Strength Hanging Test Set-up 67

TASK IV.

$120 \mathrm{AH}$ Sealed Ni-Zn Cell 75

2 Group 2C, Cel1 IIA2 77

3 Voltage \& Pressure Characteristics, $\quad 78$

Cells IIA2 \& 2C3

4 Voltage \& Pressure Characteristics, 79

Cells 2C3, 2C4, \& IIA2

5 Voltage \& Pressure Characteristics, Cell 2D1 81

6 Voltage \& Pressure Characteristics, Cell 2D2 . 82

7 Voltage \& Pressure Characteristics, Cell 2D3 83

8 Voltage \& Pressure Characteristics, Ceil 2D4

9 Cell 2El, 3A Charge 35 
Figure No.

Page No.

$10^{\circ}$ Cell 2C2, Recombination Test

87

11 Cells 2Cl and IIA2, Recombination Tests 88

12 Cells 2D3 and 2D4, Recombination Tests .89 TASK V

1 Effect of Mulling, ERC Ni \#54-102 100

2 Effect of Mulling, ERC Ni \#81-52A 101

3 Effect of Negative Additives on Cycle Life 105

4A Discharge Performance, Ni-Zn Cells (EV12,: 106 EV14 \& EVS 2)

4B Discharge Performance, Ni-Zn Cells (EV20, 107 EV22, EV23 \& EV25)

4C Discharge Performance, Ni-Zn.Cells, (EV27, 108 EV28, EVS3 \& ECAR-1)

5 J227aD, Electric Profile, Cell. EVT $10 \quad .112$

6 J227aD, Electric Profile, Cell EVT 13.113

7 Coulometer Circuit 116

8. Constancy of Voltage Drop \& Current during $\quad 117$ Charge \& Discharge

9 Characteristics of Coulometric Charge Control - 118 Charge

10 Characteristics of Coulometer during Discharge 120

11 Current Variations during Constant Voltage 121 Charging at 1.92 volts 
TASK I

I Effect of Mulling of Nickel Hydroxide Active 8 Materials

II Precipitation of $\mathrm{Co}(\mathrm{OH})_{2}$ Under Various Conditions 10 TASK II

I Cell Design Summary

II Single Electrode Test Cells

TASK III

I Physical Properties of Separator Materials 46

II Average Particle Size \& Chemical Stability 51 of Fillers

TII Phyeical Properties of Supported Film

IV Summary of pornsimetry nnalyses on P-64\& $\mathrm{P}-50 \quad 60$

$\checkmark$ Typical Diffusion Data \& Calculations 62

VT Single Electrode C.A11 Cycle Lifo Sunmasy

TASK IV

I 20 Ah sealed Cell construction Variables 74

II Group 2D Pressure Controlled Charge 80 Characteristics

II Open Circuit Gas Generation Rates · · $\quad 86$ TASK V

I Design Parameters . 96

IA Cycle Life of 20 Ah Cells 97

II Results of Mulling Experiments 99

II Evaluation of $B-1$ Addition to Negative plates 102

IV Battery/Monnhlock/Cell Tests 104

$V \quad$ Ni in Cèl] EV23, performance Characteristics 109

VI Ni-Zn Cell. Fiv25, Performance Claracteristics 110

VII Ni-Zn Ce11 EV22, Performance Characteristics 111 
SECTION I - INTRODUCTION 


\subsection{INTRODUCTION}

The report contained herein is the first annual report which reviews the progress achieved under ANL contract 31-109-38-4248. It covers the report period from $15 \mathrm{March}$ 1978 to 15 August 1978 .

The report itself is subdivided into the major areas of activity e.g., Component Development and system Engineering. The first segment of the overall program entitled,"Component Development" consists of four basic subtasks which are all proceeding in parallel. They are:

TASK I - Nickel Electrode Development

TASK II - Zinc Electrode Development

TASK III - Separator Development

TASK IV - Sealed Cell Development

Fach of these subtasks io repurted herein on a otand aloue basıs along with its uwn introduction and conclusion.

The nickel electrode dovelupment program under TASK I is directed at the oplimization of the electrical performance, specifically, in terms of increased cycle life. In addition, emphasis is being placed upon low cost manufarturing piucedures as the ERC develuped non-sintered electrode holds great promise of becoming the lowest cost nickel electrode available.

The work during this report period concentrated upon both the development of pilot plant facilities to produce nickel hydroxide and upon optimizing the manufacturing processes to produce nickel hydrnxide which has high electrochemical utilization. The pilot plant is now capable of producing in excess of $100 \mathrm{lb} /$ week of nickel hydroxide which is equivalent to approximately L2.5 KWH theoretical capacity.

The baseline nickel hydroxide has been characterized and is now being subjected to optimization via variations in processing e.g., variations in precipitation procedures, degree of washing, grinding, drying and aging prior to incorporation into electrodes.

Full size nickel electrodes are now being routinely manufactured in the pilot plant. It i.s now apparent that there are no barriers to large scale production utilizing ERC's non-sintered process. Electrodes utilizing this process have yielded 300 cycles at $85 \%$ depth of discharye in $20 \mathrm{AH}$ nickel-cadminm cells during the period with no evidence uf decay in performance.

During the next twelve (12) month period, efforts will. center on improvement in the volumetric efficiency $\left(\mathrm{AH} / \mathrm{in} \mathrm{B}^{3}\right)$ of the nickel electrode. 
The primary goal under Task II of the zinc electrode studies is to increase the cycle life of this electrode in order to achieve 400-500 deep cycles at the $\mathrm{c} / 2$ discharge rate. Prior ERC work on experimental Ag0-Zn cells has established that this level of cycle life can be achieved.

This effort is primarily concentrating on the effect of additives upon shape change and cycle performance and on the mechanistic processes involved in the shape change. The diagnostic efforts to determine the rates of formation of dendrites and the basic mechanisms involved have not as yet yielded clear data. When a viable diagnostic procedure is developed, it will have the two-fold purpose of being a tool for mechanism studies and will also be useful as a practical method to conduct accelerated testing of new electrode formulations.

During the next twelve (12) months, zinc electrode tasks will center on the effects of various additives and constructional variations upon electrode stability and cycle life. Work will continue in the area of the development of: laboratory: procedures for screening additives and quantitative determination of shape change.

TASK III, the separator effort, has as its major goal the development of a low cost separator which exhibits stabjlity in the electrolyte, has uniform pores which are of a sufficiently small size to impede the growth of zinc dendrites and exhibits low electrical resistance and good flexibility. ERC's efforts involve both in-house manufactured and commercially available separator materials. The in-house manufactured separators consist of self-supporting and supported composite films.

The process itself is now optimized for pilot plant manufacture; hundreds of formulations have been produced and subsequently screened in both the laboratory and in actual cells. Promising formulations are presently being subjected to additional characterization tests and life cycles. Additionally, any promising commercial separators which become available are immediately placed into screening programs.

During the next twelve months, selected formulations will be tested in full scale EV cells. Studies will be undertaken to improve the mass transport characteristics and new separators will. continue to be manufactured and tested.

The goal of TASK IV, the sealed cell studies, is to determine the feasibility of sealed cell operation. This task was started later than the other studies and hence has the least amount of available data. The initial exploratory studies are being undertaken in $20 \mathrm{AH}$ size cells where the rates of oxygen recombination, hydrogen generation and electrolyte concentration effects, etc. are being determined. 
TASK $V$ entitled System Engineering is the second major subdivision of this effort. It is under this task that all cells are designed and tested. Also included is the investigation of charge control devices and techniques as well as the complete analysis of all cells for failure modes.

TASK V also encompasses the accelerated testing of $20 \mathrm{AH}$ size cells. To date, large numbers of these $20 \mathrm{AH}$ cells have been subjected to this type of testing. These cells incorporated separator variations, active material additives and internal design variations. Cycle lives up to 150 deep cycles have been achieved under these accelerated conditions depending on design details.

ERC has developed a test facility under this task which is capable of testing large numbers of full scale EV cells under varied test regimes including the simulated T227 test. This test data is now routinely fed into our computer system for lata reduction and correlation. A small number of full scale cclls have been tested. To date, full size cells appear to have a lower cycle life capability than 20 AH cells. The reasons are not yet known.

Observations, thus far, include the following:

- Bonded nickel electrodes perform as well as sintered electrodes under EV test conditinns.

- Collometric charge control using pressure from a pilot $\mathrm{Ni-H_{2 }}$ cell as a signal to terminate the charge is reliable.

- Constant potential charging appears to bc one uf several promising methods. 


\section{SECTION II}

NICKEL, ELECTRODE DEVELOPMENT FOR

NICKEL-ZINC CELLS - TASK I 


\subsection{INTRODUCTION}

The goals of this phase of the ANL nickel-zinc research and development program are to reduce the cost of the bonded nickel electrode and to optimize the performance capability such that 400 deep cycles (at the $\mathrm{C} / 2$ rate) can be achieved in nickel-zinc cells.

This investigation is presently centered on the performance characterization of the ERC baseline $\mathrm{Ni}(\mathrm{OH}) 2$ and upon the scaling up of processes involved in the manufacture of electrodes.

Test procedures are being established to completely characterize $\mathrm{Ni}(\mathrm{OH}) 2$ and graphite powders with respect to particle size, surface area and bulk density. The electrochemical utilization of active material in finiched electrodes for cell design purposes will be determined by limited cycling of $\mathrm{Ni}-\mathrm{Cd}$ cells.

Experimenta1 Ni $(\mathrm{OH})_{2}$ electrodés will also be fabricated and tested to improve electrochemical utilization of active material and electrode stability. This portion of the development effort will center on the preparation of $\mathrm{Ni}(\mathrm{OH}) 2$, using several different manufacturing processes including the use of additives to the active material during preparation. Experimental electrodes will be subjected to pore size measurements before and after cycling, $X$-Ray analysis before and after cycling, and measurement of change in electrode thickness with cycling. 


\subsection{TECHNICAL DISCUSSION}

\subsection{Nickel Hydrate}

The preparation of nickel hydrate under this program was a continuation of work being done under company sponsorship. One of the objectives was to scale up the preparation of our hydrate to yield 100 pounds per week. Briefly, the preparation is carried out by precipitating a solution of cobalt nickel sulfate with an excess of potassium hydroxide. The hydrate is then washed free of alkali and sulfate.

Additional work was done to improve the preparation and electrochemical activity of the nickel hydrate. One of the problems of hydrate preparation is the relatively long time required to dry the material. To overcome this, samples of hydrate were dried at $60,80,100$ and $120^{\circ} \mathrm{C}$ to determine the temperature the hydrate could withstand and still be active electrochemica-ly. Cells have been made from these hydrates and preliminary findings will be discussed under cell Testing.

Recent emphasis has been directed toward improving the electrode capacity per unit volume. Improved utilization of the hydrate with graphite should allow less graphite to be used, thereby devoting a greater portion of the electrode volume to the active mass. The mode is to prepare hydrates having a portion of the graphite added during their preparation.

\section{$2.2 \mathrm{Ni}$-Cd Cell Tests}

The testing of experimental nickel hydrates has been carried out in nominal $20 \mathrm{AH}$ nickel-cadmium cells having 70 mil positive plates with a potassium titanate separator. With such an arrangement, it has been possible to obtain over 500 cycles at the $\mathrm{C} / 2$ rate before the capacity fell to $50 \%$ of the initial value. A new series of cells was made with hydrates prepared by varying washing and drying conditions and was put on test.

After 100 cycles, these cells had dropped to 60-80\% of their initial capacity so the cells were set aside to determine the reason for the anomalous behavior. Cells made at the same time, but not filled with electrolyte, were taken apart and in one case the pack was tightened and in the other fuel cell. asbestos was substituted for potassium titanate. Neither of these variables improved cell performance. Electrode preparation was investigated next.

In the proparation of bonded positive electrodes, nickel hydrate, graphite and Teflon are mulled between rullers to develop a cohesive mass. A test was made of the amount of this mulling upon the performance. of subsequent electrodes: The nickel hydrates chosen were two types.

These hydrates were used to make nominal $20 \mathrm{AH}$ nickelcadmium cells with the positive plate materials mulled normal, in excess of normal and less than normal. The separator used 
TABLE I

EFFECT OF MULLING GF NICKEL HYDROXIDE ACTIVE MALERIALS 20 AH $\mathrm{Ni}-\mathrm{Cd}$ CELLS

TYPE II

TYPE I

DEGREE OF MUELING

INITIAL CAP. AH:

OVER

NORMA-

UNDER

17.7

OVER

17.1

NORMAL

17.3

UNDER

CELL VOLTAGE

At 1 hour/ I hour +55 mizutes or Capacity to 0.20 Volt

Cycle 1

Cycle 13

Cycle 61

$\begin{array}{llllll}1.116 / 0.993 & 1.093 / 18.5 & 1.094 / 18.7 & 1.132 / 1 \varepsilon .7 & 1.129 / 1.006 & 1.131 / 19.0 \\ 1.133 / 1.019 & 1.108 / 0.911 & 1.102 / 0.866 & 1.153 / 1.065 & 1.144 / 1.061 & 1.148 / 1.063 \\ 1.139 / 1.010 & 1.056 / 17.7 & 1.023 / 16.3 & 1.160 / 1.065 & 1.137 / 1.043 & 1.159 / 1.061 \\ 1.135 / 0.986 & 1.025 / 17.5 & 1.018 / 17.2 & 1.164 / 1.063 & 1.133 / 1.036 & 1.168 / 1.067 \\ 1.134 / 0.975 & 0.097 / 16.2 & 0.981 / 16.0 & 1.175 / 1.056 & 1.133 / 1.021 & 1.177 / 1.060 \\ 1.123 / 0.948 & 0.965 / 15.8 & 0.953 / 15.3 & 1.170 / 1.039 & 1.122 / 0.988 & 1.175 / 1.046 \\ 1.118 / 0.932 & 0.953 / 15.7 & 0.925 / 14.5 & 1.165 / 1.029 & 1.115 / 0.995 & 1.171 / 1.042 \\ 1.116 / 0.892 & 0.924 / 14.8 & 0.883 / 14.0 & 1.168 / 1.032 & 1.122 / 0.995 & 1.174 / 1.044 \\ 1.129 / 0.904 & 0.826 / 11.3 & 0.800 / 11.0 & 1.171 / 1.027 & 1.136 / 1.019 & 1.178 / 1.051 \\ 1.101 / 0.879 & ---/ 7.7 & ---/ 8.8 & 1.152 / 1.012 & 1.118 / 1.020 & 1.160 / 1.038 \\ 1.116 / 0.824 & ---/ 4.6 & ---/ 6.8 & 1.163 / 0.982 & \Xi .137 / 1.003 & 1.173 / 1.022\end{array}$

\section{Cycle 106}

Cyole 142

Cycle 163

Cycle 184

Cycle 205

Cycle 229

Cycle 247

Cycle 268
1. $116 / 0.824$
$1.173 / 1.022$ 
was nylon cloth and Pelion. These cells have been on a cycle of a six-hour charge at 3.7 amperes followed by a two-hour discharge at 10 amperes representing an 85\% depth of discharge. The cells have gone through 268 discharge cycles and representative monitored cycle data is shown in the attached table. This data shows the initial improvement in capacity with cycling. The general superiority of the Type I hydrate over the Type II confirms previous observations. The Type II hydrate test cells clearly show the need for maximum mulling.

The experimental samples of Type I hydrate dried at 60 , 80, 100 and $120^{\circ} \mathrm{C}$ were made into nominal $20 \mathrm{AH} \mathrm{Ni-Cd}$ test cells using the overmulled preparative procedure. The results show the average of the midpoint voltages at the $\mathrm{c} / 2$ rate was initially decreased 50 millivolts due to the higher drying temperature. With four formation cycles, this difference decreased to 20 millivolts. The total cell capacities improved gradually with cycling but are independent of drying temperature.

\section{3 $\mathrm{Ni}(\mathrm{OH}) 2$ Characterization Studies}

Studies were initiated to determine why $\mathrm{Ni}(\mathrm{OH}) 2$ electrodes made by rolling show a slight tendency to swell during cyclic operation.

Aging experiments were begun to determine what conditions influence the formation of beta-Ni(OH) 2 during the preparation of the active material.

Initially, precipitation experiments were set up in which $\mathrm{Co}(\mathrm{OH}) 2$ was precipitated under various conditions from $\mathrm{CoSO}_{4}$ salt. The hydroxides of cobalt are iso-structural with beta$\mathrm{Ni}(\mathrm{OH}) 2$ and form hydrothermally from the blue alpha-Co(OH) 2 . The precipitation experiments with $\mathrm{Co}(\mathrm{OH}) 2$ therefore provide immediate visual evidence of what conditions produce the beta or the alpha hydroxide.

Table II gives the various experimental conditions under which $\mathrm{Co}(\mathrm{OH}) 2$ samples were prepared along with the visual results obtained.

The results indicate that precipitation of $\mathrm{Co}(\mathrm{OH}) 2$ at room temperature results initially in formation of blue alpha$\mathrm{Co}(\mathrm{OH}) 2$ which changes to the pink beta form on standing in the solution. $\mathrm{Co}(\mathrm{OH}) 2$ precipitated at $80^{\circ} \mathrm{C}$ regardless of the $\mathrm{KOH}$ concentration formed the pink beta type immediately. 
TABLE II

PRFETTPTTATION OF CO(OH) 2 UNUEK VARTOUS CONDITIONS

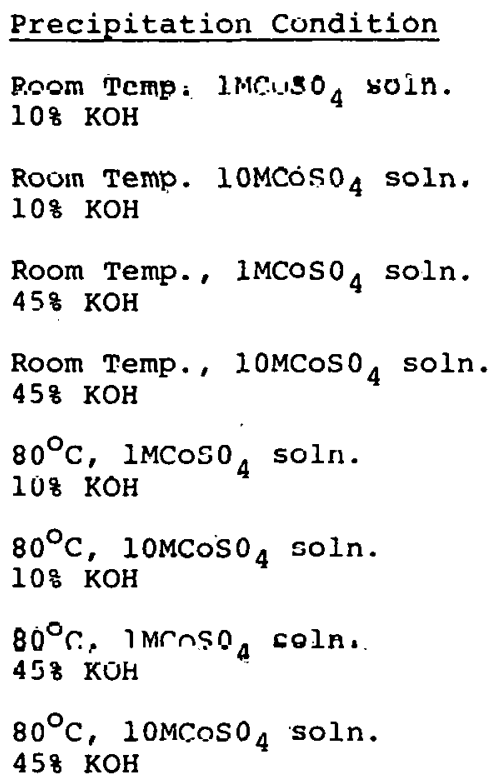




\section{0 CONCLUSIONS}

Work has been in progress to determine the optimum conditions necessary for the precipitation of $\mathrm{Ni}(\mathrm{OH}) 2$. This included the effect of washing, grinding, drying and aging on the ultimate electrochemical properties of the material. The process for preparing $\mathrm{Ni}(\mathrm{OH}) 2$ has been scaled up to produce about 100 pounds per week.

$\mathrm{Ni}(\mathrm{OH})_{2}$ bonded electrodes have been prepared and tested in Ni-Cd cells which are capable of over 300 cycles at 80 \% DOD.

During the next 12 months, work will focus on improving the volumetric efficiency $\left(\mathrm{AH} / \mathrm{in}^{3}\right)$ of the nickel electrode. 
THIS PAGE

\section{WAS INTENTIONALLY \\ LEFT BLANK}


SECTION III

ZINC ELECTRODE DEVELOPMENT FOR

NICKEL-ZINC CELLS - TASK II 


\subsection{INTRODUCTION}

The primary goal of this phase of the component study will be to develop stable zinc electrode structures which are capable of at least 400-500 deep cycles (at the $c / 2$ rate) in nickel-zinc cells.

It will be the object of this investigation to answer the following questions related to the mechanisms of zinc shape change in a working cell:

1. How do the rates of deposition and dissolution of zinc differ from the edge to the center of the electrode?

2. How do these rates djffer as a function of oyoling?

3. What are the rate-controlling steps for depusitiun and dissolution of $z$ inc at growth steps or nucleation sites on the filertrode?

4. How is the nature of the zinc deposit affected by substrate material?

5. How do additives to the active zinc material effect shape change?

6. How does the distribution of additives change in the zinc electrode with cycling?

The effects of the various electrode construction variables on shape change will be investigated in terms of their contributión to changes in current distribution within the electrode during cycling.

Seqmented electrodes will be cycled and the current distribution will be monitored during various stages of life. The use of this type of set-up will allow analysis of shape change trends since uneven current distribution will result in unequal distribution of zinc.

In addition to the individual electrode studies, full size Ag-Zn and Ni-zn cells will. be fabricated with various zinc electrode structures to determine their cyclic performance capabilities under practical conditions. 


\subsection{TECHNICAL DISCUSSION}

A zinc electrode test was set up using segmented $z$ inc electrodes to monitor current distribution between the sections during various stages of cell life.

Preliminary tests indicated that split zinc electrodes develop gross distortions in the normal current density patterns with cycling. This results in non-reproducible data. Because of these anomalies, split positive silver electrodes were used as counter electrodes to measure changes in current patterns with cycling.

Results after 3 months do not clearly show that this technique will give an indication of zinc electrode shape change.

\subsection{Procedure}

Initially four single, segmented electrode cells were constructed to perfect the mechanical assembly details and to collect some preliminary data. Each cell was constructed with bonded $\mathrm{Ni}(\mathrm{OH}) 2$ electrodes, with one zinc electrode sandwiched between two nickel half plates. Each cell had one layer of Pellon (2506K4) on the zinc electrode and two layers of PVA $\left(0.0015^{\prime \prime}\right)$ around the nickel electrodes (Figure I). The complete electrode assemblies were inserted into transparent polyethylene bags and placed into plexiglass stands (Figure 2): to allow visual observation of electrode changes. A 35: potassium hydroxide (KOH) solution with l\% lithium hydroxide ( $\mathrm{LiOH}$ ) was used as the electrolyte. The electrodes are the same size as those used in ERC's $250 \mathrm{Ah}$ cells.

of Cells A,B,C\&D (Table I), two were constructed with the zinc electrodes split vertically into three separate sections of equal area. These sections were connected through independent shunts to a common bus bar. This permitted current and voltage measurements to be taken for each section (Figure 2A).

The four cells were cycled continuously on a regime consisting of a two-hour discharge at a 10 amp current and a. six-hour charge at 3.67 amps. Cells reaching a discharge voltage of 0.80 were automatically removed from the circuit for the remainder of the discharge. Discharge current vs. time measurements were recorded for each section of the two segmented electrode cells in addition to recording voltages for all the cells.

Three additional single electrode cells (SI, S2\& S3) were built with silver positive electrodes instead of nickel electrodes (see Table II). All the cells contain the same zinc formulation; however, Cell $\mathrm{s} 3$ has a layer of an inert conductor and a binder pressed onto the negative electrode between the $\mathrm{Zno}$ layer and the copper current collector (see Figure 3) in an attempt to help prevent $z$ inc shape change. 


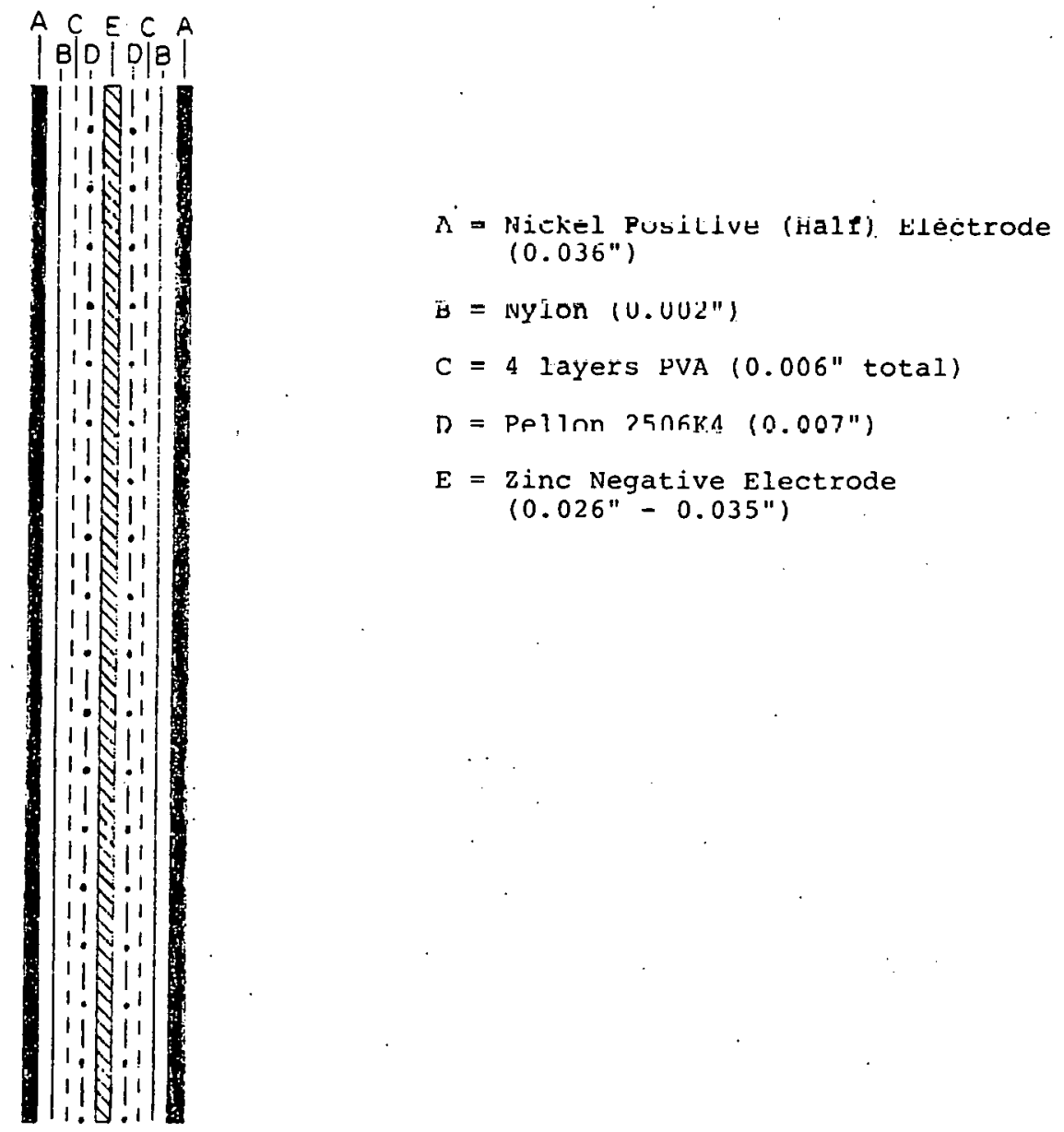

Figure 1 - Electrode Arrangement 


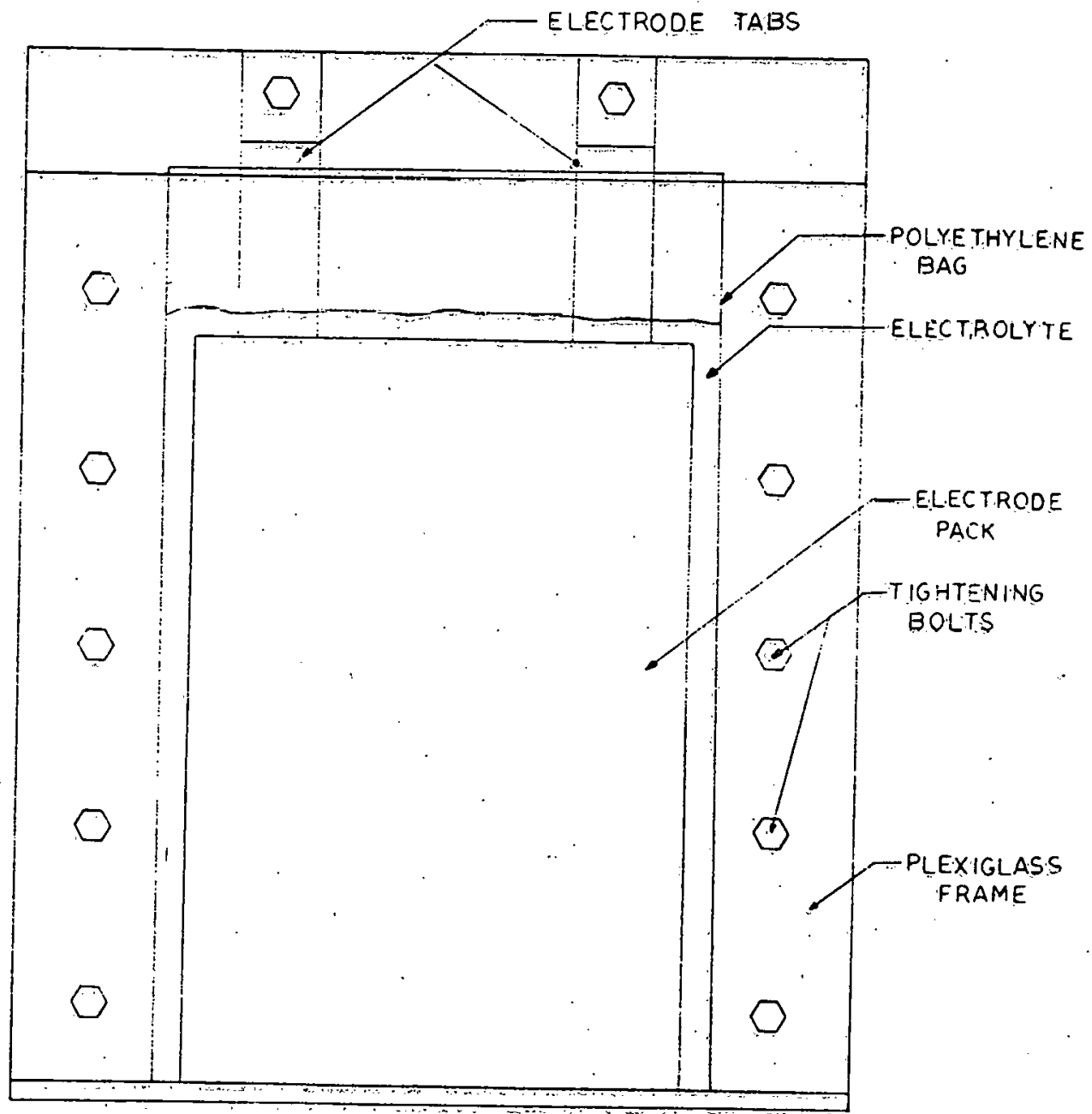

Figure 2 - single Electrode Cell 
TABLE I - CELL DESIGN SUMMARY

\begin{tabular}{|c|c|c|c|c|}
\hline CELL & A. & B & $\begin{array}{lllll}c & \ldots & \ldots & \ldots & \ldots\end{array}$ & $\therefore D$ \\
\hline Positive Electrode & & & & $\cdots \quad \because \cdots$ \\
\hline Number & 2-half electrodes & 2-half electrodes & 2-hajf electrodes & 2-half electrodes \\
\hline Size & $6-1 / 4 " \times 9-1 / 2 "$ & $6-1 / 4 " \times 9-2 / 2^{n}$ & $6-1 / 4 "=9-1 / 2 "$ & $6-1 / 4 "$ " $\times 9-1 / 2 "$ \\
\hline Thickness & $0.036^{\prime \prime}$ & $0.036^{\prime \prime}$ & D.03E" & $0.036^{\prime \prime}$ \\
\hline $\begin{array}{l}\text { Theoretical } \\
\text { Capacity }\end{array}$ & $23.6 \mathrm{AH}$ & $24.1 \mathrm{AH}$ & $23.8 \mathrm{AE}$ & $24.14 \mathrm{AH}$ \\
\hline Negative Electrode & & & & \\
\hline Number & 1 full & 1 full & 1 split & 1 split \\
\hline Size & $6-1 / 4 " \times \quad x-3 / 2 "$ & $6-1 / 4 " \times 9-1 / 2 "$ & $5-1 / 4 " \times 9-1 / 2 "$ & $6-1 / 4 " \times 9-1 / 2 "$ \\
\hline Thickness & $0.026^{\prime \prime}$ & $0.035^{\prime \prime}$ & $0.026^{\prime \prime}$ & $0.035 "$ \\
\hline $\begin{array}{l}\text { Theoretical } \\
\text { Capacity }\end{array}$ & $41.5 \mathrm{AH}$ & $55.7 \mathrm{AH}$ & 11.O AH & $41.9 \mathrm{AH}$ \\
\hline Zinc Mix Densit $y$ & $45 \mathrm{gm} / \mathrm{in}^{3}$ & $45 \mathrm{gm} / \mathrm{in}^{3}$ & $45 \mathrm{gm} / \mathrm{in}^{3}$ & $35 \mathrm{gm} / \mathrm{in}^{3}$ \\
\hline Additive & cao & cdo & $\operatorname{cdo} 0$ & Inert \\
\hline $\mathrm{Zn} /$ ai Ratio & 1.76 & 2.31 & 1.72 & 1.72 \\
\hline
\end{tabular}




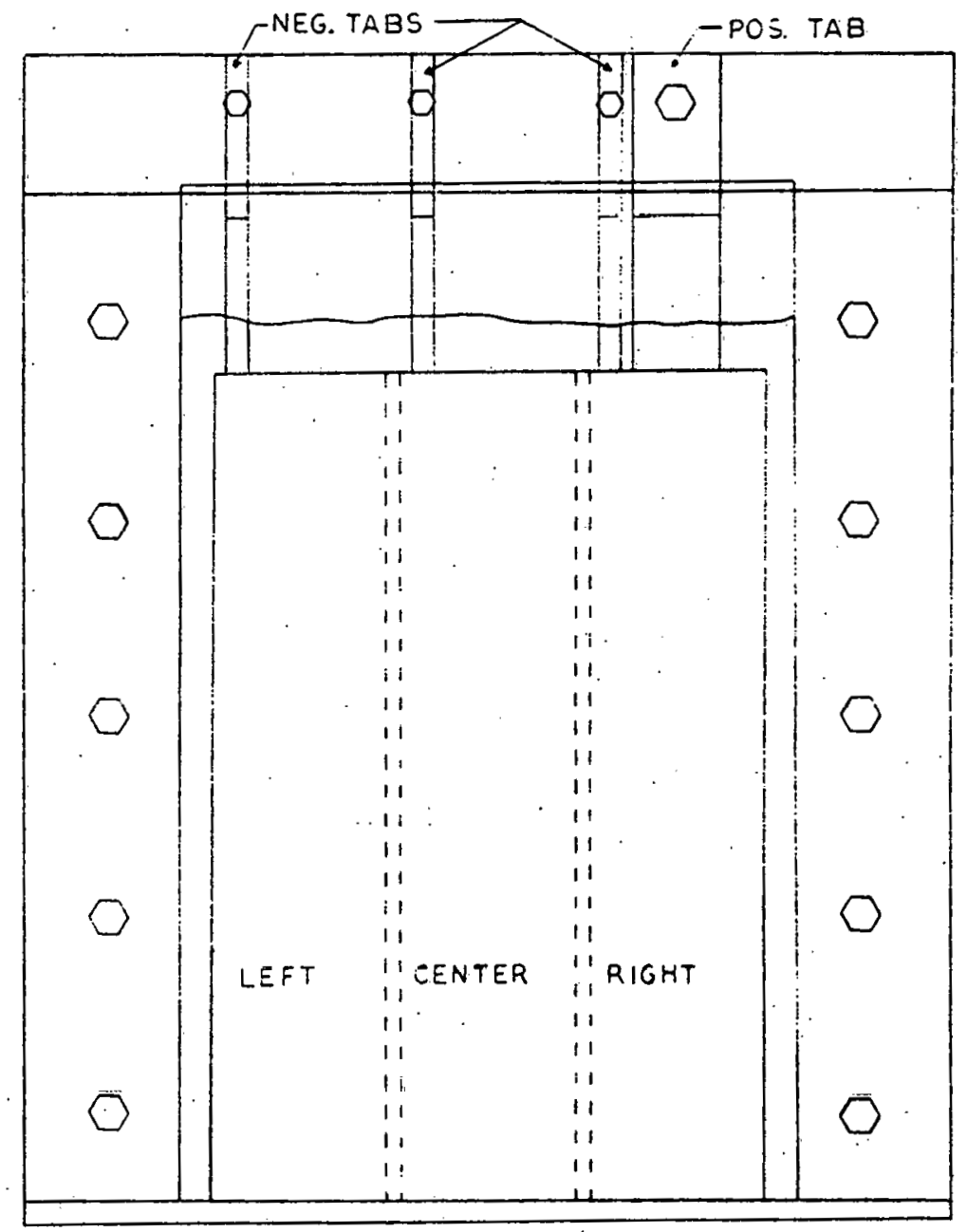

Figure 2A - SINGLE ELECTRODE CELL WITH SPLIT ZINC ELECTRODE 
TABLE II

SINGE ELECTRODE TEST CELLS

\begin{tabular}{|c|c|c|c|c|c|c|c|c|}
\hline CELL & SI & S2 & S3 & S4 & S5 & SG & $\mathrm{T} 1-\mathrm{T} 3$ & $\mathrm{NZ}-1$ \\
\hline $\begin{array}{l}\text { POS ITIVE } \\
\text { ELECTRODE }\end{array}$ & Silver & Silver & Silver & Siこver & Silver & SEiver & Nickel Exmet & Impregnated Nickel \\
\hline NUMBER & $1 \mathrm{FuIl}$ & 1 Full-Split & l Full-Split & l Full-Split & 1 FuL1 & 1 Full-Sp-it & & 2 Half \\
\hline SIZE & $6 f^{\prime \prime} \times 9^{\prime \prime}$ & $61^{\prime \prime} \times 9^{\prime}$ & $67^{\prime \prime} \times 9^{\prime \prime}$ & $67^{\prime} \times 9^{\prime \prime}$ & $64^{\prime \prime} \times 9^{\prime \prime}$ & $6311 \times 91$ & $6 \frac{1}{4} 1^{\circ} \times 9^{\prime \prime}$ & $64^{\prime \prime} \times 9^{\prime \prime}$ \\
\hline THEO. CAP. & $40 \mathrm{Ah}$ & $40 \mathrm{Ah}$ & $40 \mathrm{Ah}$ & $40 \mathrm{Ah}$ & $40 \mathrm{Ah}$ & $40 \mathrm{Ah}$ & & \\
\hline $\begin{array}{l}\text { NEGATIVE } \\
\text { ELECTRODE }\end{array}$ & Zinc & $\underset{\vdots}{\operatorname{zinc}}$ & Zinc & Zinc & $\begin{array}{l}\text { Zinc } \\
3 \% \text { TFE }\end{array}$ & $\begin{array}{l}\text { Zinc } \\
3 \% \text { TFE }\end{array}$ & $\begin{array}{l}\text { Zinc } \\
3 \% \text { TFE }\end{array}$ & $\begin{array}{l}\text { Zinc } \\
3 \% \text { TFE }\end{array}$ \\
\hline NUMBER & 2 Half & 2 Half. & $2 \operatorname{Half}$ & $2 \mathrm{Half}$ & $2 F u l i$ & 2 Full & 1 Full & 1 Full \\
\hline SIZE & $6 \frac{1}{2} \times 9^{\prime \prime}$ & $6 \frac{11}{4} " \times 9^{\prime \prime}$ & $6 z^{\prime \prime} \times 9 "$ & $6 \frac{1}{4} " 1 \times 9 "$ & $6 \frac{7}{11} \times 9^{\prime \prime}$ & $6 \frac{1}{4} \cdot \times 9^{\prime \prime}$ & $67^{\prime \prime} \times 9^{\prime \prime}$ & $6 \frac{11}{4} \times 9 " 1$ \\
\hline THEO. CAP. & $75.6 \mathrm{Ab}$ & $75.6 \mathrm{Ah}$ & $75.6 \mathrm{Ah}$ & $75 . \overline{\mathrm{Ah}}$ & $74.2 \mathrm{kh}$ & $74.2 \mathrm{Ah}$ & $74.2 \mathrm{Ah}$ & $74.2 \mathrm{Ah}$. \\
\hline ADDITIVE & $\mathrm{CdO}$ & Cdo & $\begin{array}{l}\text { inert } \\
\text { layer } \\
\text { collector }\end{array}$ & $\mathrm{CdO}$ & $\begin{array}{l}\text { inert } \\
\text { layer } \\
\text { collector }\end{array}$ & $\begin{array}{l}\text { inezt } \\
\text { lager } \\
\text { co Eector }\end{array}$ & $\begin{array}{l}\text { inert } \\
\text { layer } \\
\text { collector }\end{array}$ & $\begin{array}{l}\text { inert } \\
\text { layer } \\
\text { collector }\end{array}$ \\
\hline SEPARATOR & FSC & FSC & FSC & FSC & FSC & FS: & PVA & PVA \\
\hline NO. CYCLES & 177 & 75 & 170 & 75 & .21 & 21 & 88 & \\
\hline $\begin{array}{l}\text { PRESENT } \\
\text { PLATEAU VOLTAGE }\end{array}$ & 1.40 & $\begin{array}{l}\text { Disassembled } \\
7 / 20 / 78\end{array}$ & 1.35 & $\begin{array}{l}\text { Off Test } \\
8 / 1 / 78\end{array}$ & 1.48 & $1.4 \mathrm{C}$ & 1.09 & \\
\hline $\begin{array}{l}\text { CAPACITYY TO } \\
0.80(\mathrm{Ah})\end{array}$ & 14.1 & & 11.6 & & 20.3 & 11.3 & 17 & \\
\hline
\end{tabular}




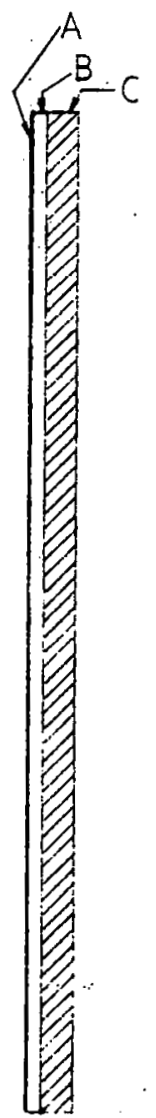

$$
\begin{aligned}
& A=\text { Copper current collector } \\
& B=C A O+T F E \\
& C=\mathrm{ZnO}+\mathrm{CAO}+\mathrm{TFE}
\end{aligned}
$$

FIGURE 3 - Céll s3, zinc Half Electrode Construction 
Cells S2 \& S3 were constructed with the silver electrode split vertically into three sections of equal area (Figure 4). Both the positive and negative plates were covered with an absorber layer of Pellon (2506K4) and three layers of FSC as a separator (figure 5). The cells were filled with a 45\% potassium hydroxide (KOH) solution with l\% lithium hydroxide ( $\mathrm{LiOH}$ ). Cells S1 and 52 were cycled continuously on a regime consisting of a two-hour discharge at a 10 amp current and a sixhour charge at 3.67 amps. A low voltage limit of $0.80 \mathrm{~V}$ was set to remove cells with low voltage from the circuit. Cell s 3 was cycled with a two-hour discharge at 8.0 amps $\left(4.1 \mathrm{~mA} / \mathrm{cm}^{2}\right)$; the reduced current density was used to duplicate the current density in the 250 Ah E.V. cell tests.

Cell S4 was constructed as a duplicate of S2. Tt had one full, split, positive electrode between two zinc half electrodes. Pelion (2506K4) was used as an absorber layer on both the positive and negative plates. Three layers of FSC were used as a separator. The electrolyte was a solution of $45 \%$ potassium hydroxide (KOH) and 1.\% lithium hydroxide (LiOH).

Three "dummy" cells ( $T 1, T 2, \& \mathrm{~T} 3$ ) were constructed with one full zinc electrode sandwiched between nickel exmet which was used as a "dummy" positive electrode. The negative electrodes contained $\mathrm{ZnO}, \mathrm{Cd} 0$, and TFE. Each of the negative electrodes had an inert conductive layer pressed into it between the Zno layer and the copper current collector. pellon (2506K4) was used as an absorber layer on the negative plate. Two layers of PVA were used as a separator.

Cell S5 was built with one full. silver electrode sandwiched between two zinc ëlectródès. The negative electrodes are the same as those in Cells $\mathrm{T} 1, \mathrm{~T} 2$, and $\mathrm{T} 3$ and have an inert conductive layer pressed into the negative electrode between the zno and the silver current collector.

Cell s6 was built with one full, silver positive electrode between two zinc electrodes which were identical to those of Cell S5. The silver electrode was split vertically into three sections of equal area. Pellon (2506K4) was used as an absorber layer on both the posj.tive and negative plates. Three layers of FSC were used as the main separator in both cells. The electrolyte was a. $45 \% \mathrm{KOH}$ solution. Nz-l was constructed with one full zinc plate sandwiched between two impregnated nickel plates. The negativc plate contained zno, cdu, TFE. It had an inert conductive layer on the riurrent collectur and was also treated. Pellon $(2506 \mathrm{~K} 4)$ was used as an absorber layer on the negative electrode and nylon was the plate envelope of the positive. The separator was three layers of DVA.

\subsection{Results}

Upon completion of the first ten cycles, Cells A, B,C and $D$ exhibited constant discharge pèrformances with cell capacities ranging from 15-17.5 ampere-hours to a $1.25 \mathrm{~V}$ cut-off 


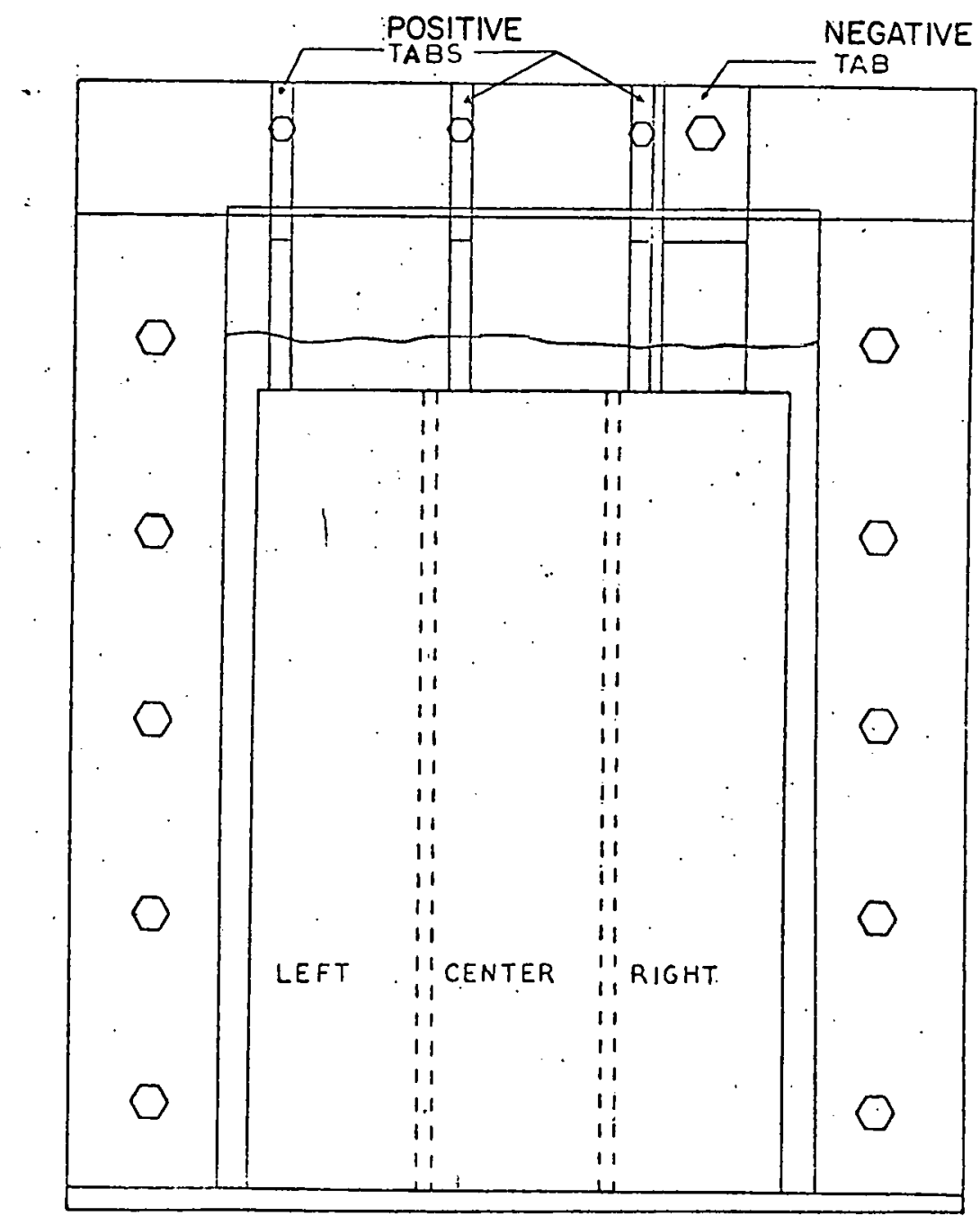

FIGURE 4. SINGLE EIECTBCEE CELL UITH SPLIT SILVER ELECTRODE 

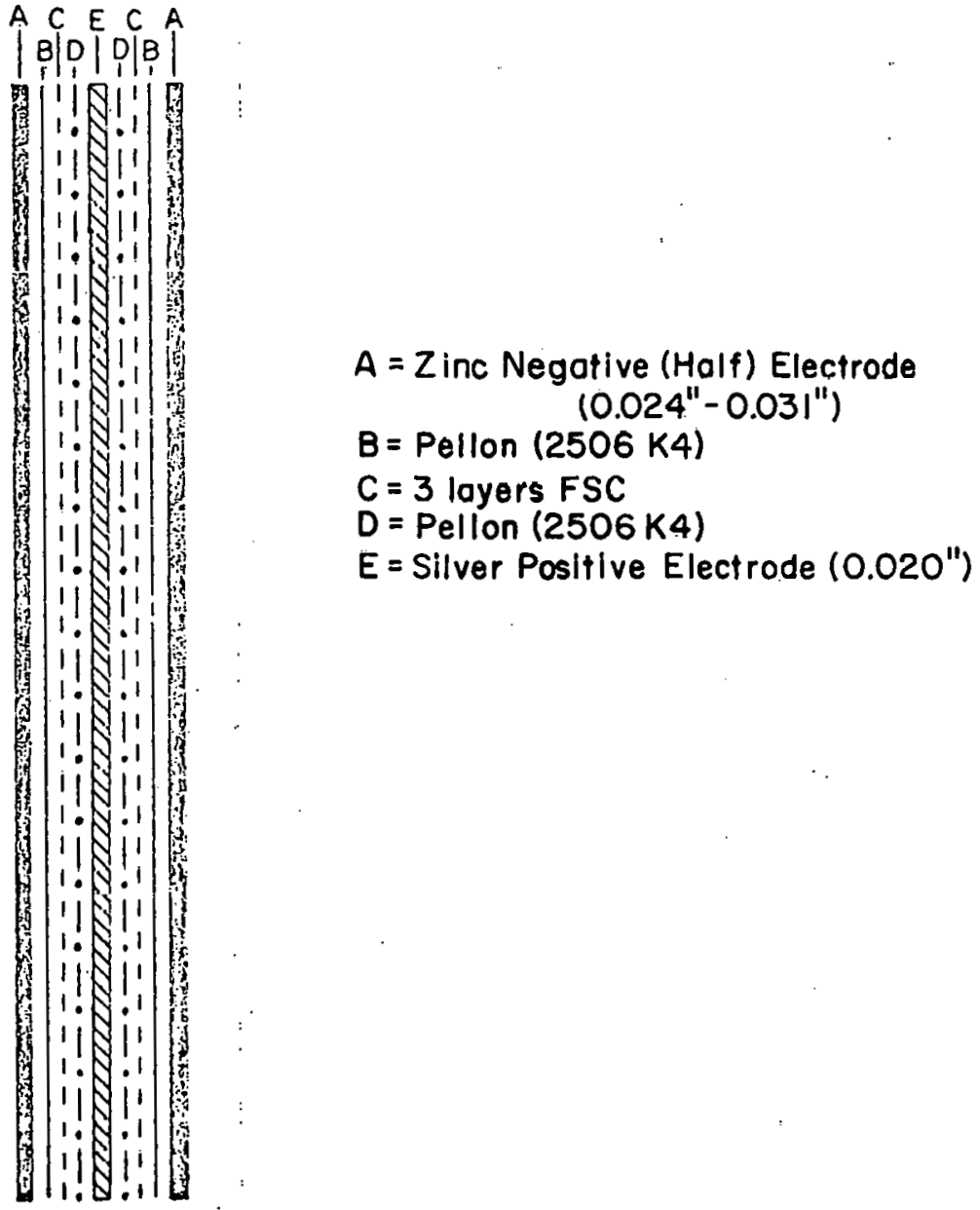

FIGURE 5, ELECTRODE ARRANGEMENT 
point. During these early cycles the cells were limited by the capacity of the nickel electrodes which yielded between $62-72 \%$ of the theoretical active material utilization. After the tenth cycle, the cell capacities began to decline as well as the average cell voltages. Discharge curves for two of the cells are shown in Figures $6 \& 7$.

After 45 cycles, Cells A,B, C and D yielded only 25-45\% of the theoretical nickel utilization. Cell A was removed from the circuit after 45 cycles while cell B was removed after completion of 65 cycles. Tear-down analyses performed on these cells revealed a great degree of zinc shape change with a loss of 50-70\% of the active area of the electrode geometric area. There was also a significant amount of zinc dendrite growth through the PVA separator with evidence of $z$ inc shorting which probably contributed to the low cell capacities.

Cells C \& D, the split electrode cells, were left on continuous cycle for a total of 121 cycles. Figures 8 and 9 show the current distribution among the sections of the $\mathrm{zinc}$ electrode for the two inert conductive additives. It can be seen that the current was shared fairly equally among the sections until about $75 \%$ of the discharge was completed at which time the center of the electrode assumed the greatest portion of the current load. This condition was more exaggerated in the later cycles as the zinc shape change became more pronounced.

Finally, the two split electrode cells were dissected in order to visually observe the electrode shape change and to determine the cause for the cell's capacity degradation. As was observed in Cells $A \& B$, there was a large amount of $z$ inc dendrite growth through the PVA. This resulted in some shorting of the cell and a loss in capacity. There was no shift of zinc material to the center section because the sections acted as separate zinc electrides with the active material shifting towards the center portion of each individual section.

cell sl has presently completed 217 cycles. The discharge voltage profile (Figure l0) illustrates that the cell capacity has been dropping.

Cell s2 completed 105 cycles before it was disassembled. Its last discharge voltage profile and section current vs. time plot are presented in Figure 11 and Figure 12. Cel1 s 2 was disassembled after 75 cycles. The suspected short was confirmed during the dissection and the cell was reassembled. Jpon reassembly it completed an additional 30 cycles with its final capacity being $10.6 \mathrm{Ah}$.

Cell S3 has presently completed 224 cycles. Its discharge voltage profile and section current information are presented in Figures 13 and 14. Its performance has dropped during cycling (See Figure 13). Its present capacity is $9.3 \mathrm{AH}$ 


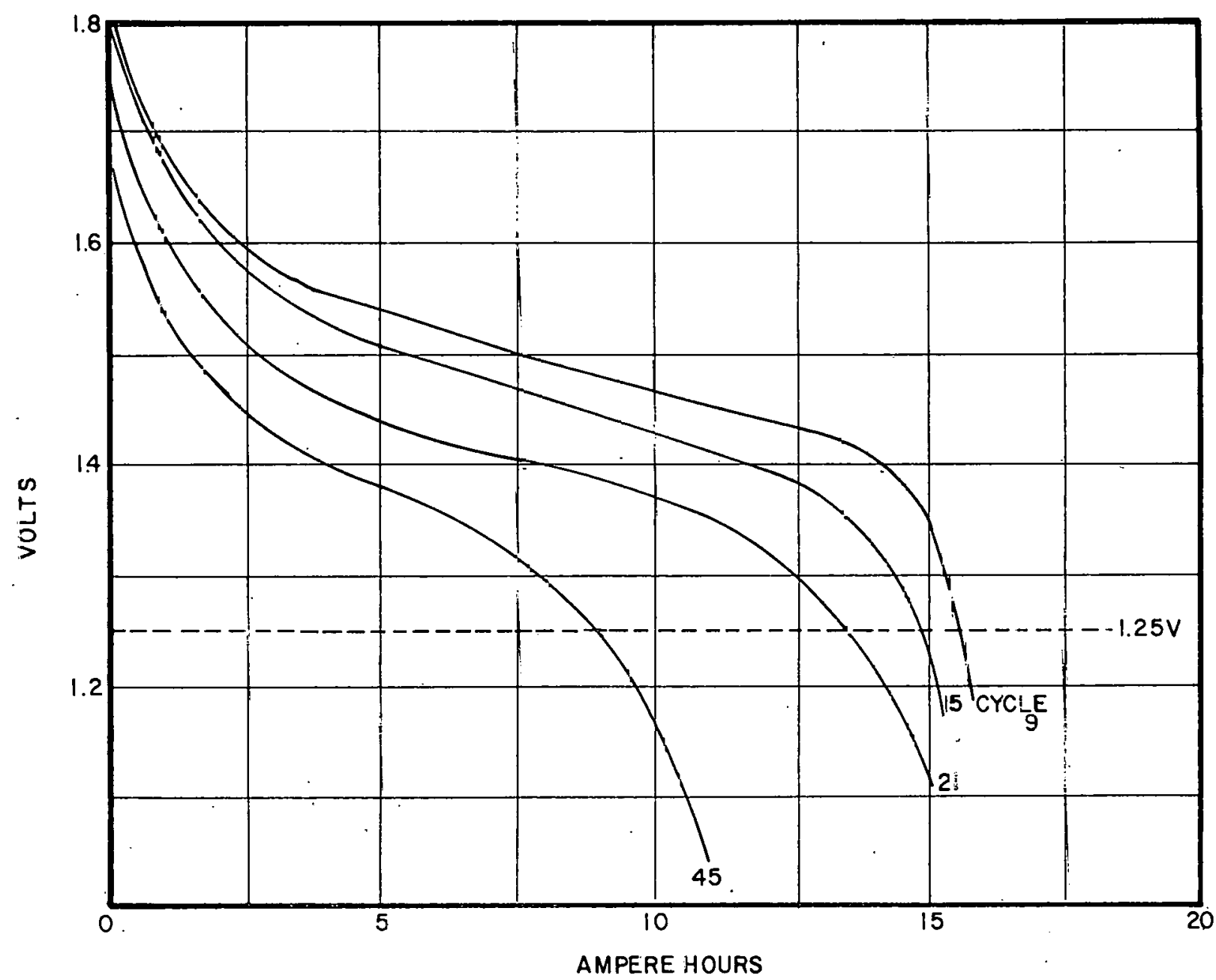

FIGUPE 6. Cell A, 10A Discharge 


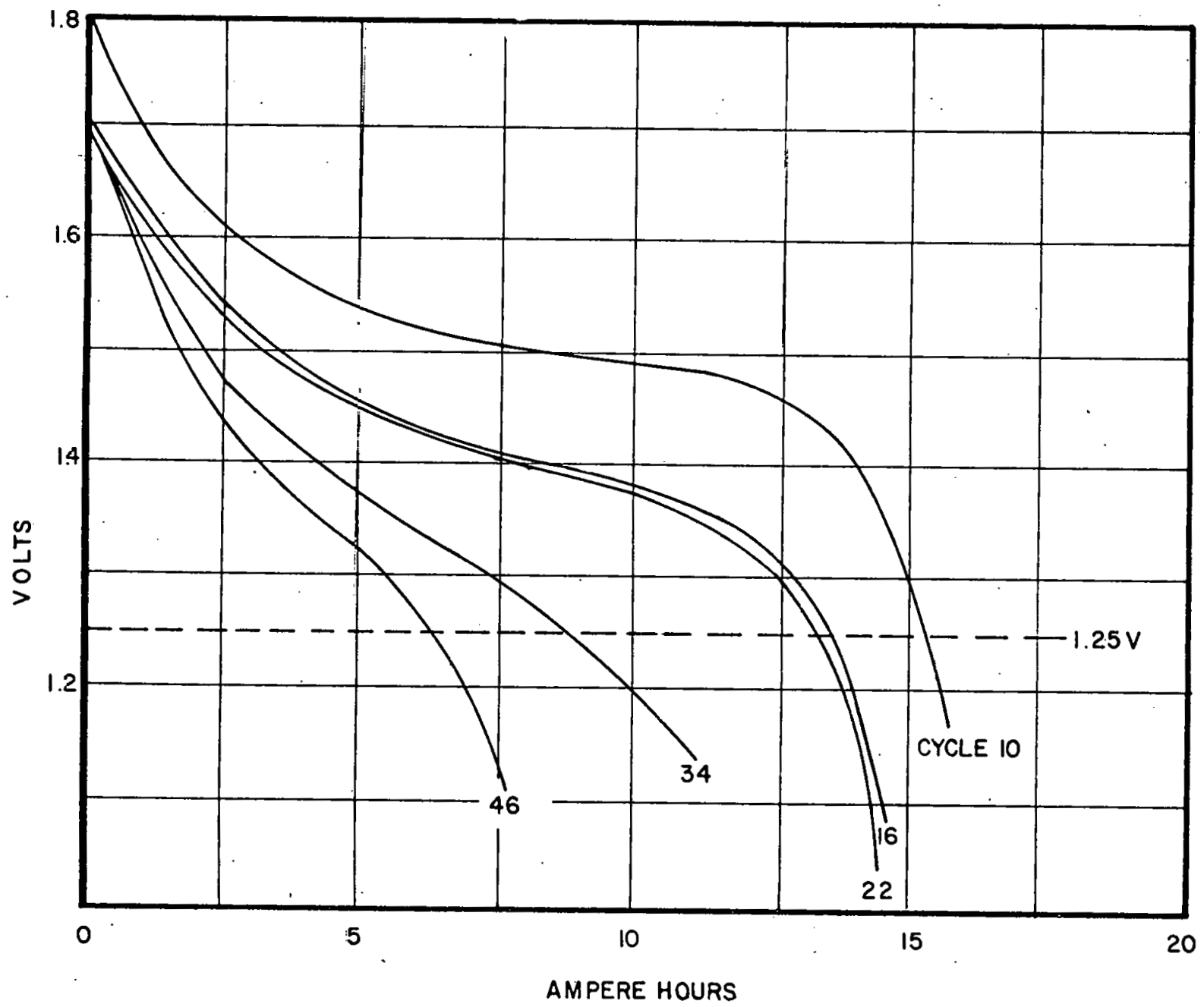

FIGURE 7. Cell B, 10R Discharge 


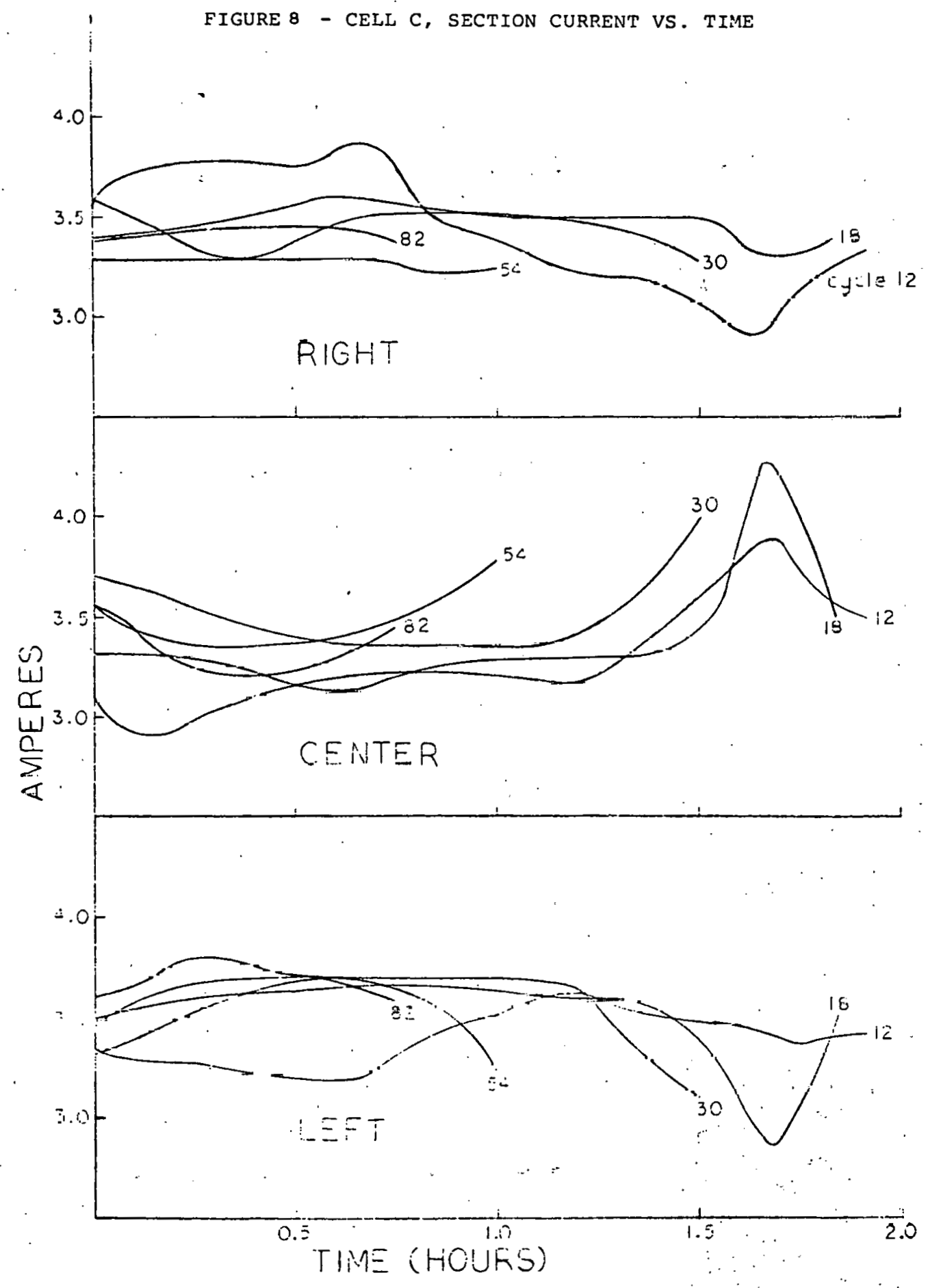




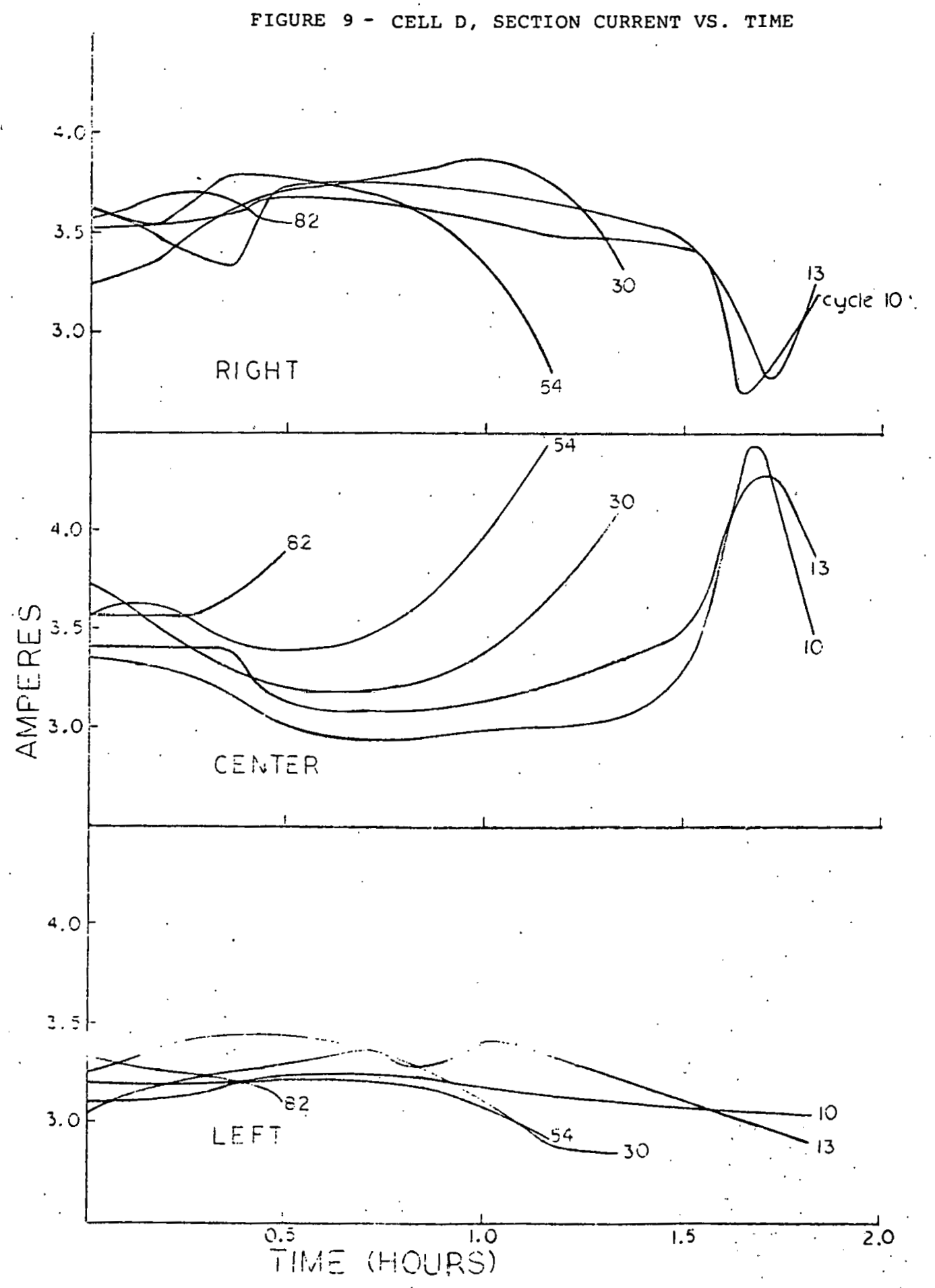




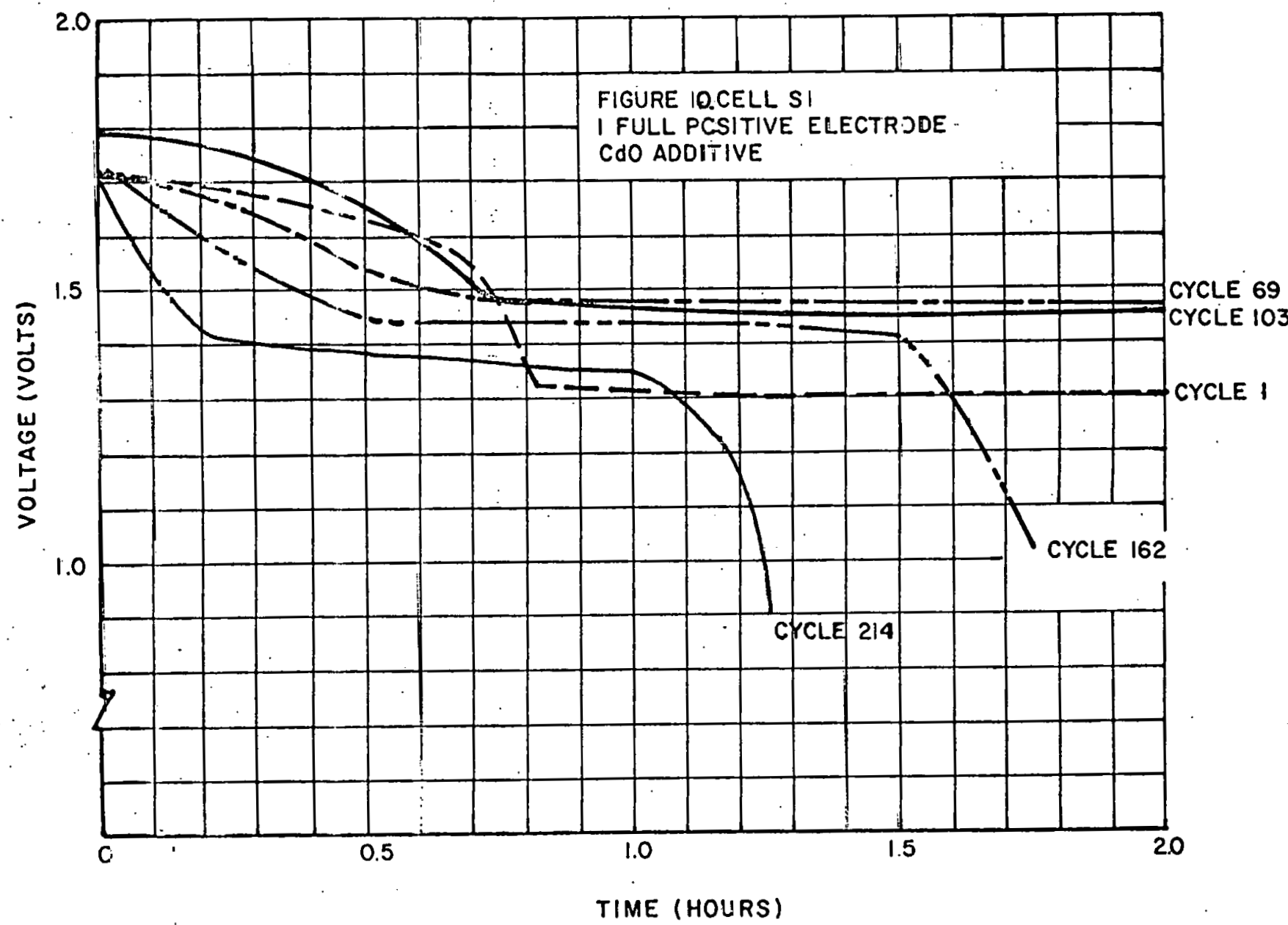




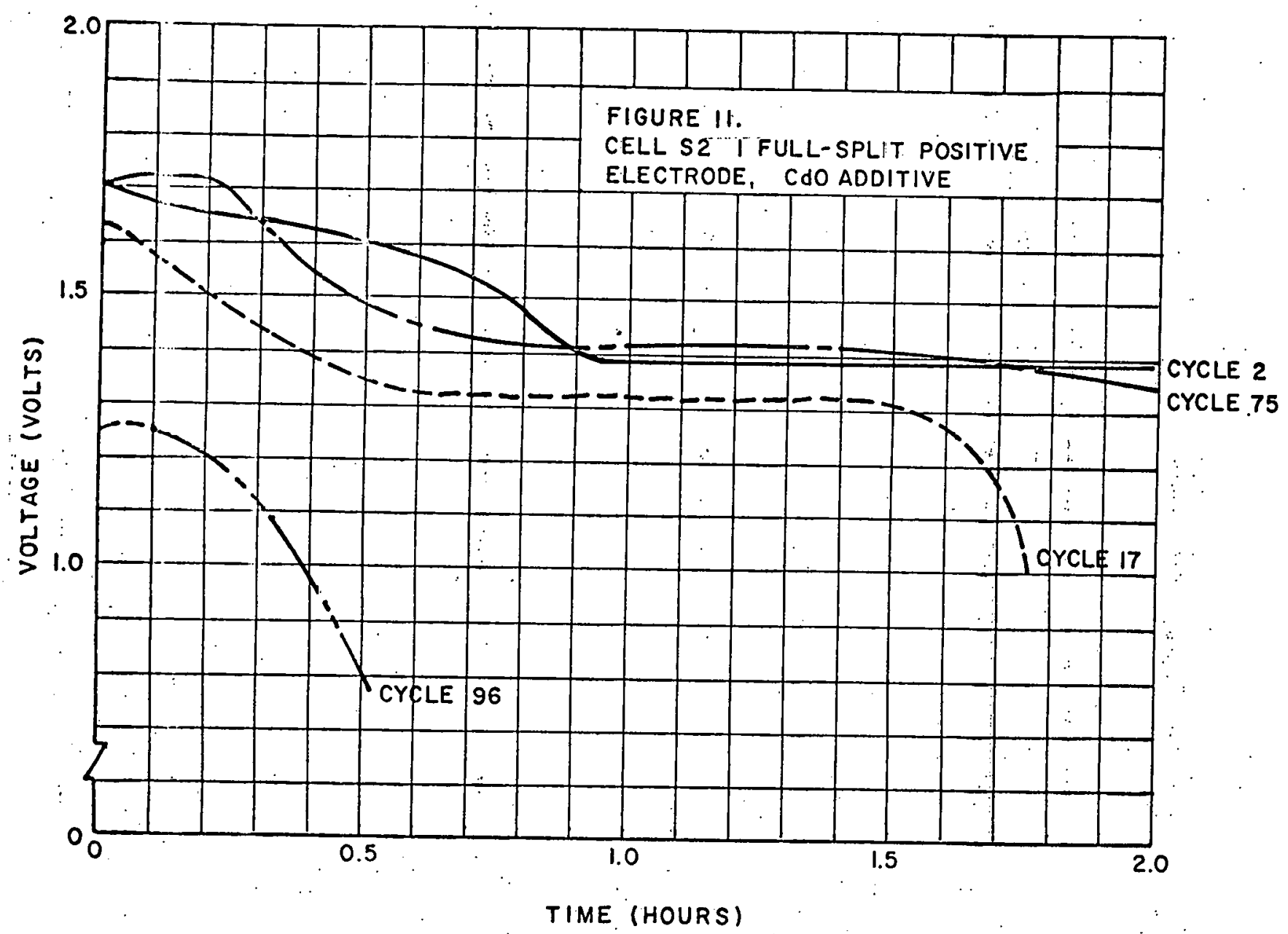



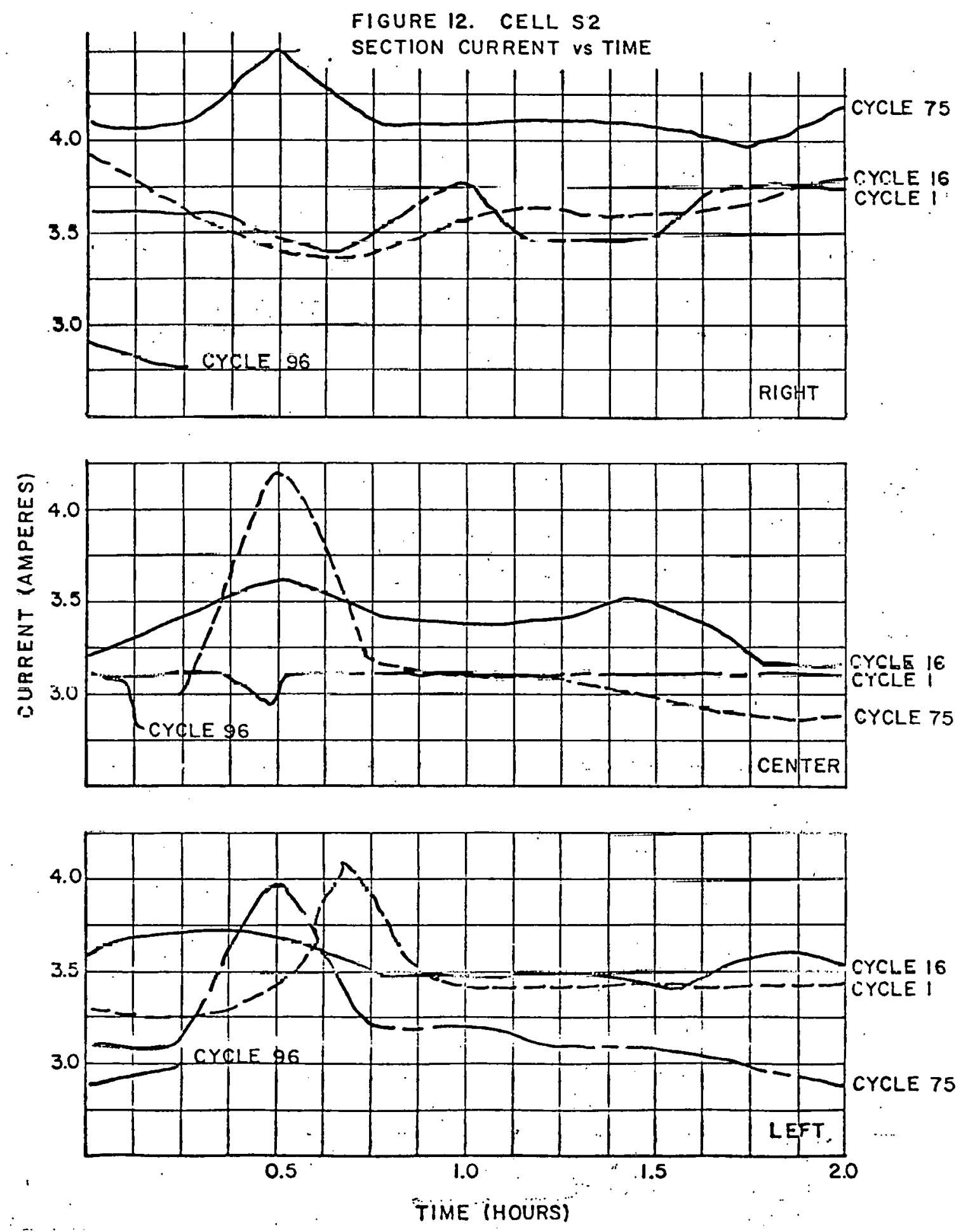


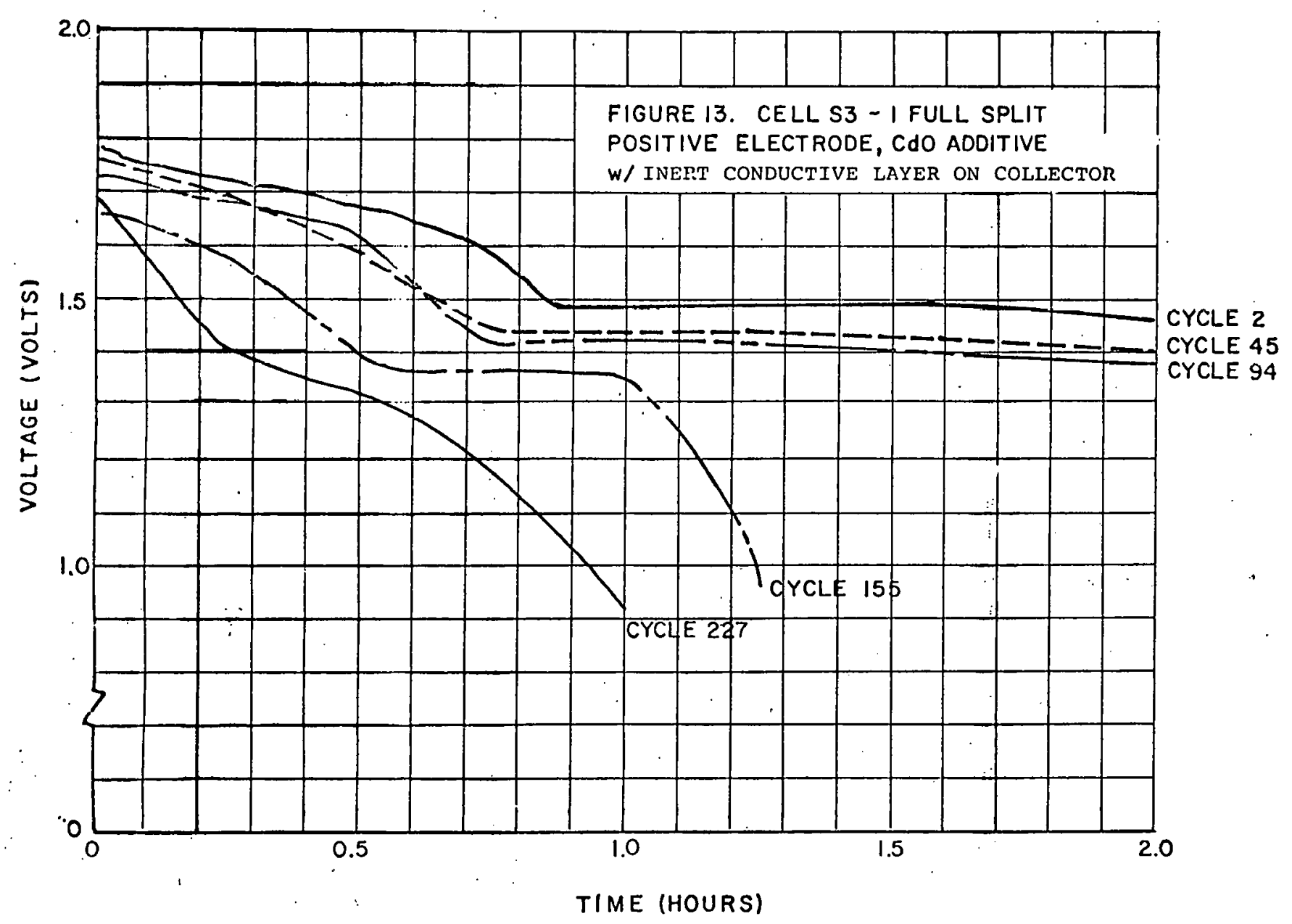


FIGURE 14. CELL $S 3$

SECTION CURRENT VS TIME
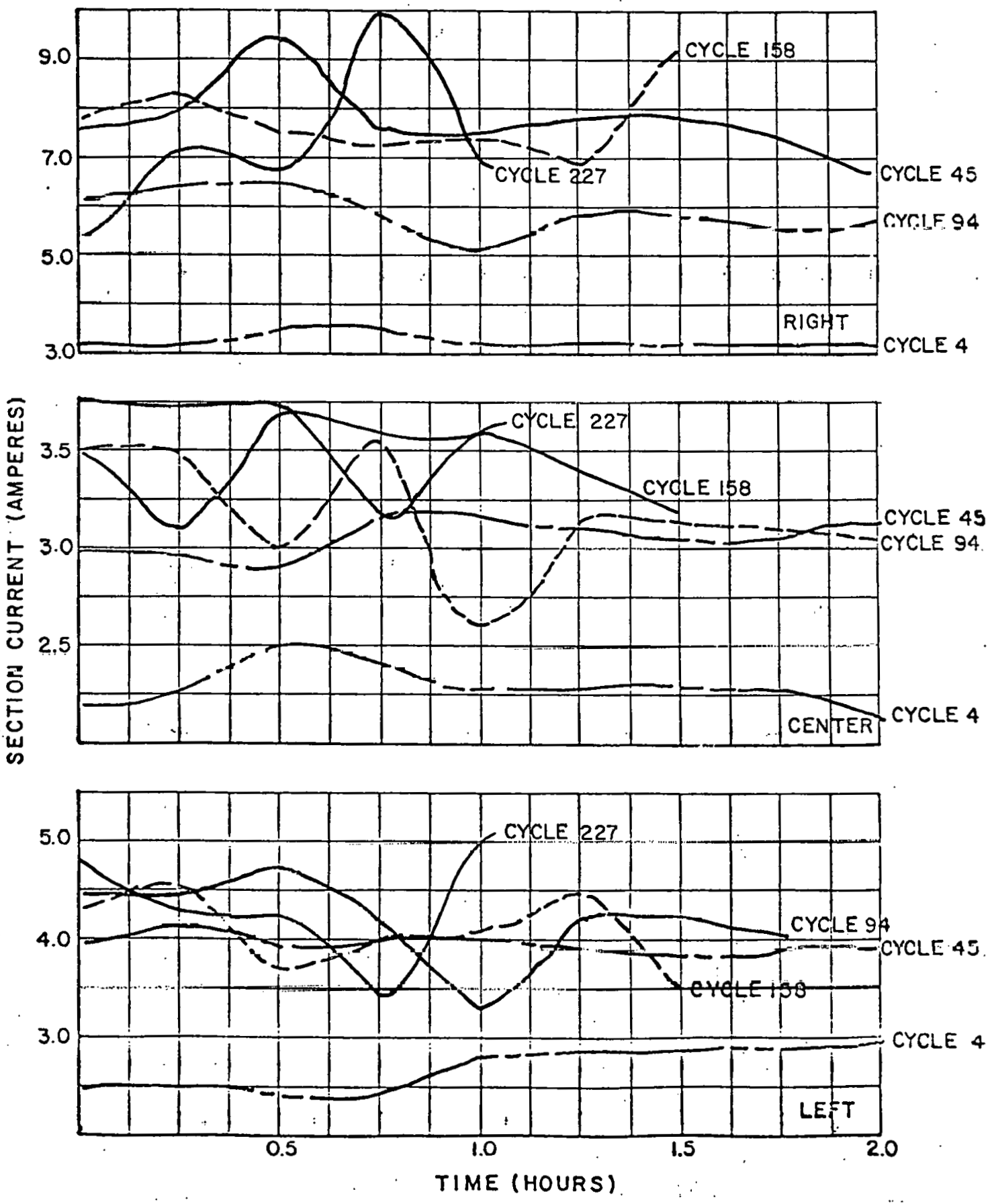
as opposed to $22 \mathrm{AH}$ during its 60 th cycle. Figure 14 illustrates that there has been a consistent distribution of current between the three sections. The center section has constantly been carrying a smaller fraction of the current than either of its neighboring sections; the current load shared by the right side is also larger than that of the left section. This same current distribution was seen in split silver cells (S2 \& S4).

Cell S4 was removed from test after having completed 75 cycles. A duplicate of Cell S2, Cell S4 showed a decline in performance and had a final capacity of $2 \mathrm{AH}$. Its final information is presented in Figures 15 and 16.

Cell S5 has presently completed 78 cycles. Its discharge voltage profile can be seen in Figure 17. During the first 9 cycles the performance was fairly stable; since then, its capacity has dropped.

Cell s6 has also run 78. cycles. The discharge voltage profile as well as section current data are presented in Figures 18 and 19. It can be seen that the cell capacity has dropped significantly.

cells $\mathrm{T} 1$ and $\mathrm{T} 2$ were removed from cycle after 97 cycles. These cells showed a decline in performance during their life; this may be due to the lack of voltage cut-off as "dummy" cells. cell $\$ 3$ was removed after 111 cycles at which point it had a capacity of only $4 \mathrm{AH}$. 


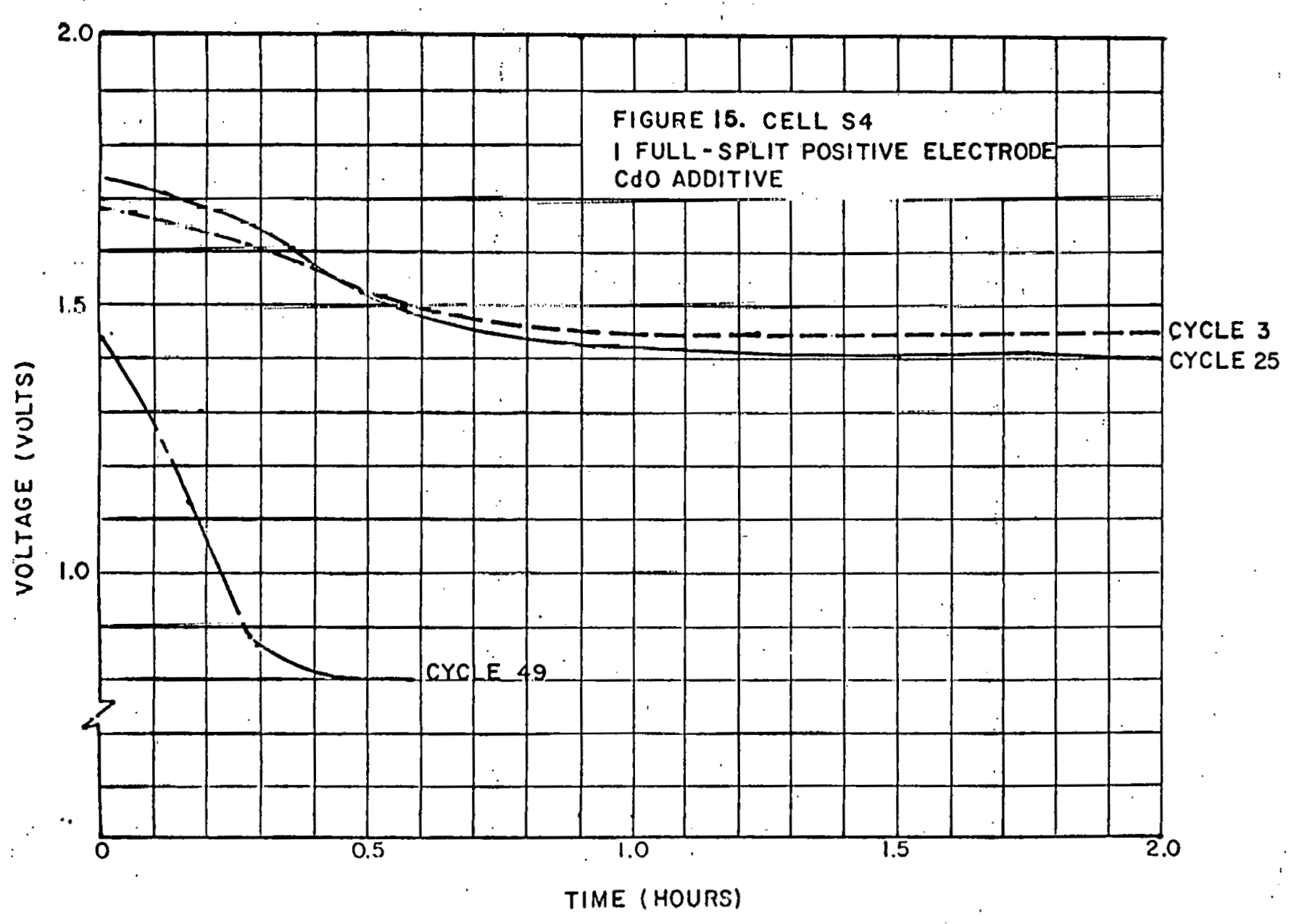


FIGURE 16. CELL S4

SECTION CURRENT VS TIME
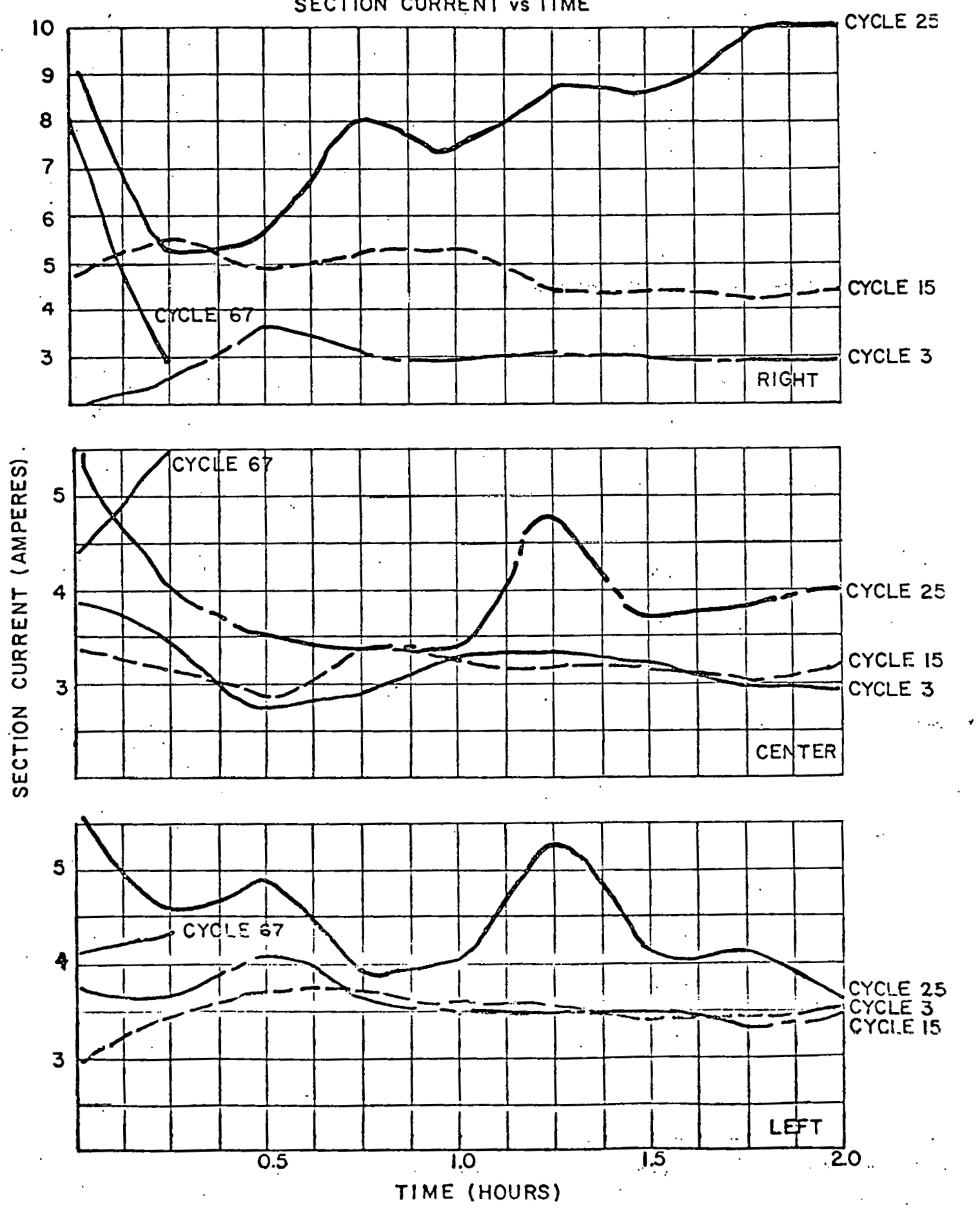


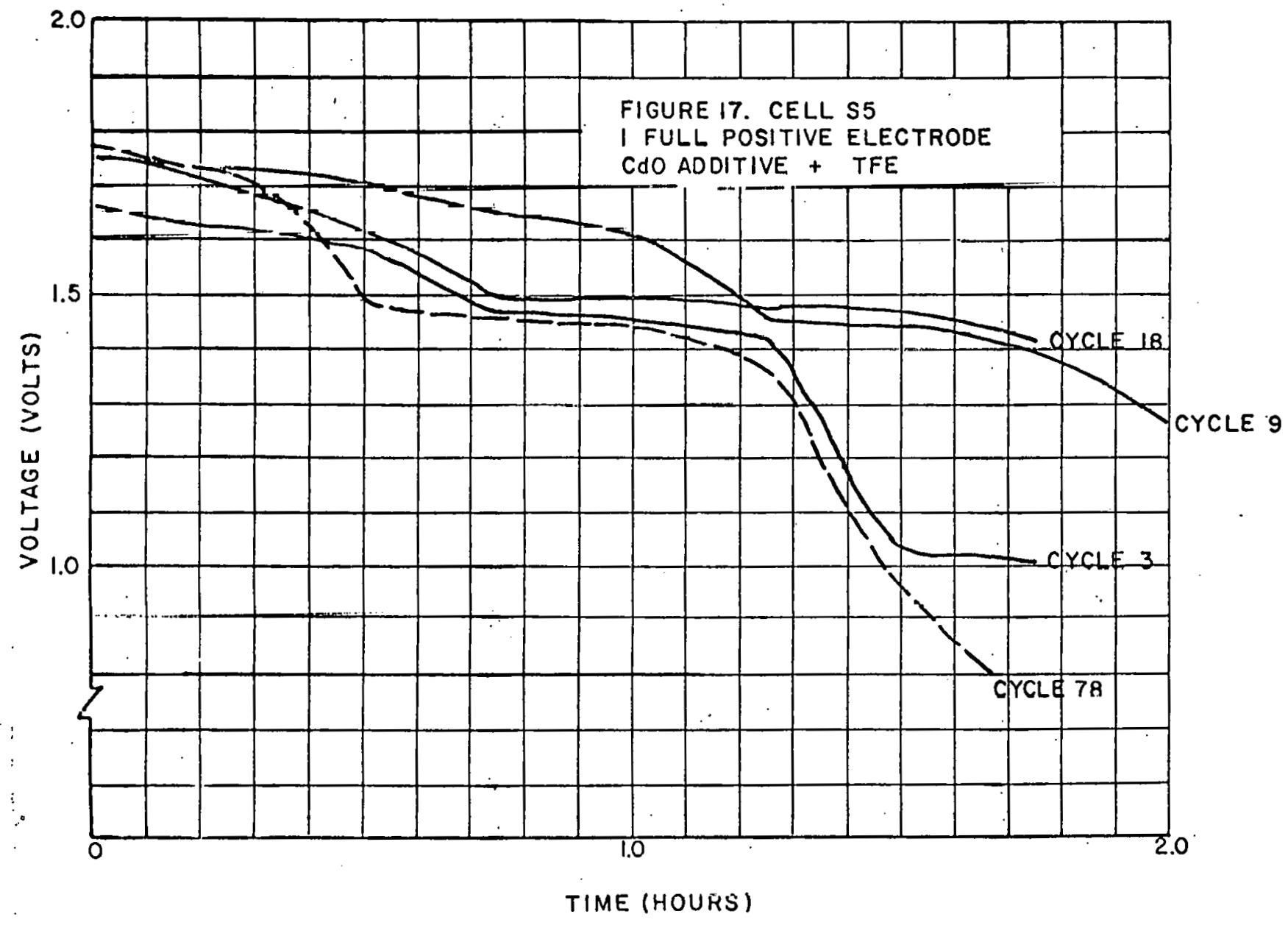

TIME (HOURS) 
FIGURE 18. CELL S6

SECTION CURRENT VS TIME
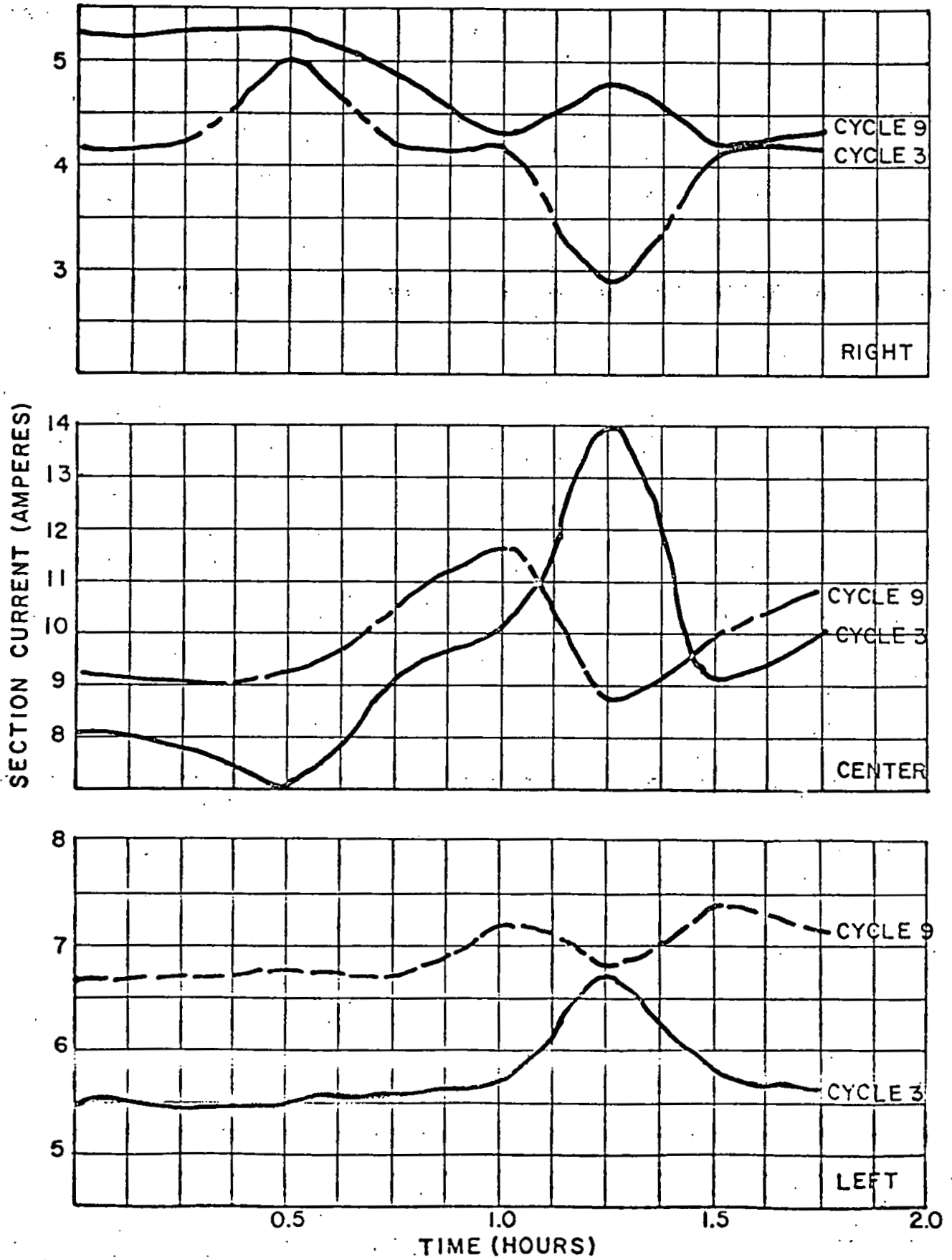


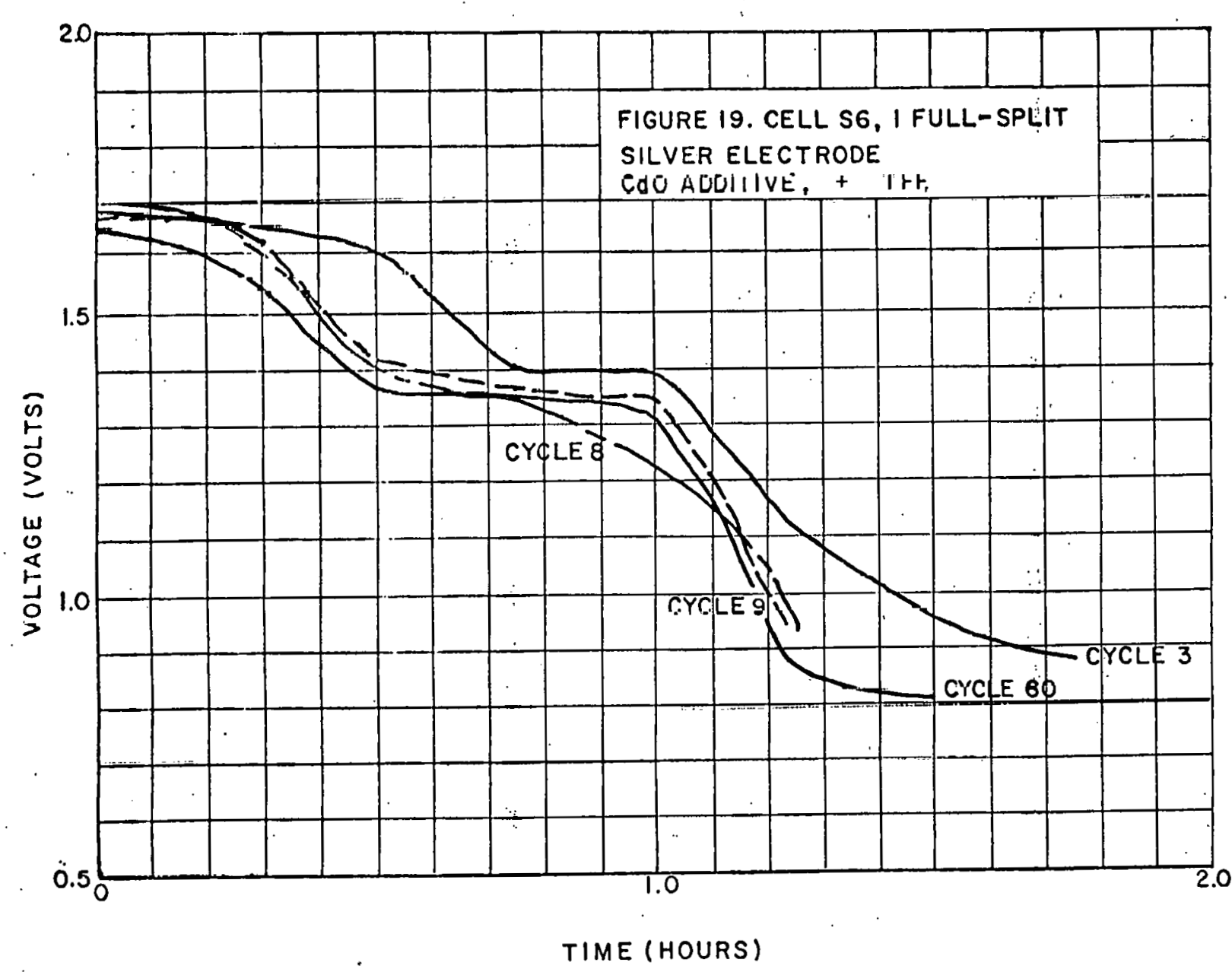




\subsection{CONCLUSIONS}

Based on the data obtained thus far, it appears that the use of sectioned electrodes as a tool for monitoring zinc shape change is not reliable in its present form.

During the next 12 months the zinc electrode study will center on the effects of various constructions and additives on shape change in both $20 \mathrm{AH}$ and $250 \mathrm{AH}$ size cells.

Experimental work on the effect of current distribution and passive layer formation will be studied at the single electrode level to determine the mechanisms of zinc shape change. 


\section{THIS PAGE}

\section{WAS INTENTIONALLY \\ LEFT BLANK}


SECTION IV

SEPARATOR DEVELOPMENT FOR

NICKEL-ZINC CELLS - TASK III 


\subsection{INTRODUCTION}

Separator degradation and its influence on zinc electrode shape change is one of the life-limiting factors of Ni-zn cells.

The goal of this task in the component optimization program will be to develop a low-cost separator which is physically and chemically stable in $\mathrm{KOH}$, is flexible, has a uniform pore size and exhibits low electrical resistivity.

The investigation will include both self-supporting and supported films utilizing various formulations. Appropriate solvent/solute and wetting agent ratios will be selected for each of the combinations.

Separators will be subjected to both physical and electrochemical screening tests to fully chararterize each type of material before experimental cells are fabricated for cyclic testing. The most critical parameters will bo electrical resistivity, pore size, and chemical stability.

Promising candidate separators will be evaluated in both vented and sealed Ni-Zn cells. It is important to evaluate the materials under both conditions since the properties desired of a separator for a sealed cell may be different than those required for vented cells. 


\subsection{TECHNICAL DISCUSSION}

The separator program has been directed towards developing new separator materials as well as evaluating the best commercially available separator materials.

As part of this program several screening test methods have been and are in the process of being developed.

\subsection{Self supporting Cast Films}

A number of chemically stable thermoplastics have been filled with both $\mathrm{KOH}$ soluble and insoluble fillers.

Techniques for filling plastics include: 1) filling with an inorganic compound which leaches out of the separator in the cell leaving minute pores for electrolyte permeability and wettability, 2) filling with a $\mathrm{KOH}$ stable compound which creates tortuous channels in the separator along the separator filler interface and 3) a combination of $\mathrm{KOH}$ leachable and stable fillers. In addition to these techniques, formulations with plasticizers and wetting agents were tested.

Data summarized in Table I indicates that $\mathrm{KOH}$ soluble fillers are necessary in most plastic films. The most promising filled separator developed by ERC is designated P-64.

Some one mil plastic films tend to be brittle and the incorporation of a plasticizing agent greatly enhances the flexibility of the film.

The non-hydrogen bonding methylenedichloride $\left(\mathrm{MeCl}_{2}\right)$ solvent system proved ideal for dispersion of some fillers which creates a hydrogen bonded network of its own in the solvent. Conversely other fillers with a positive charge showed a tendency to clump and resist dispersion in the solvent.

Various insoluble fillers were evaluated; particle size and chemical stability data for these fillers is contained in Table II. At this time, no best choice can be made on insoluble fillers and more work is needed for characterization. Insoluble fillers can function to enhänce wettability, electrical resistance, and to reduce separator shrinkage on the carrier after casting. Attempts to produce films with emulsions of both ethylene glýcol and glycerine failed, due to breakdown of the emulsion during the casting process.

In an effort to improve the wettability and electrolyte retention character of some plastic materials, a large organo-nickel complex has been added to the P-64 formulation. P-97-88 includes 1\% nickel octoate. P98-88 includes 5\% nickel stearate. Performance character of these films remains to be determined. 
TABIE I

PHYIICAL PROPERTIES OF SEPARATCR MATERIR.LS

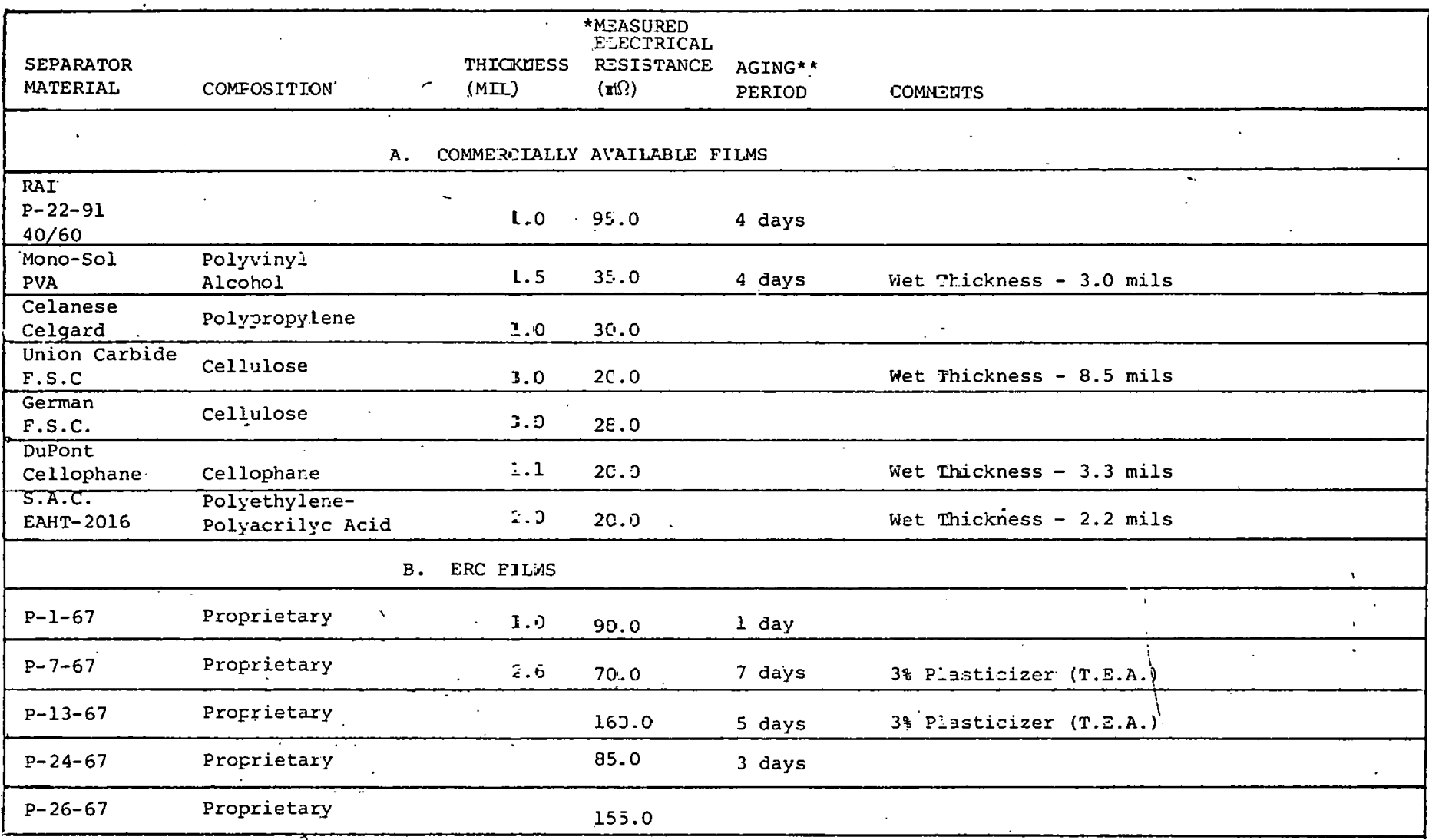

${ }^{*}$ For an area of $0.7 \varepsilon$ in $^{2}$

**Prior to Test 
TABLE I

PHYSICAL PROPERTIES OF SEPARATOR MATERIALS

(Continued)

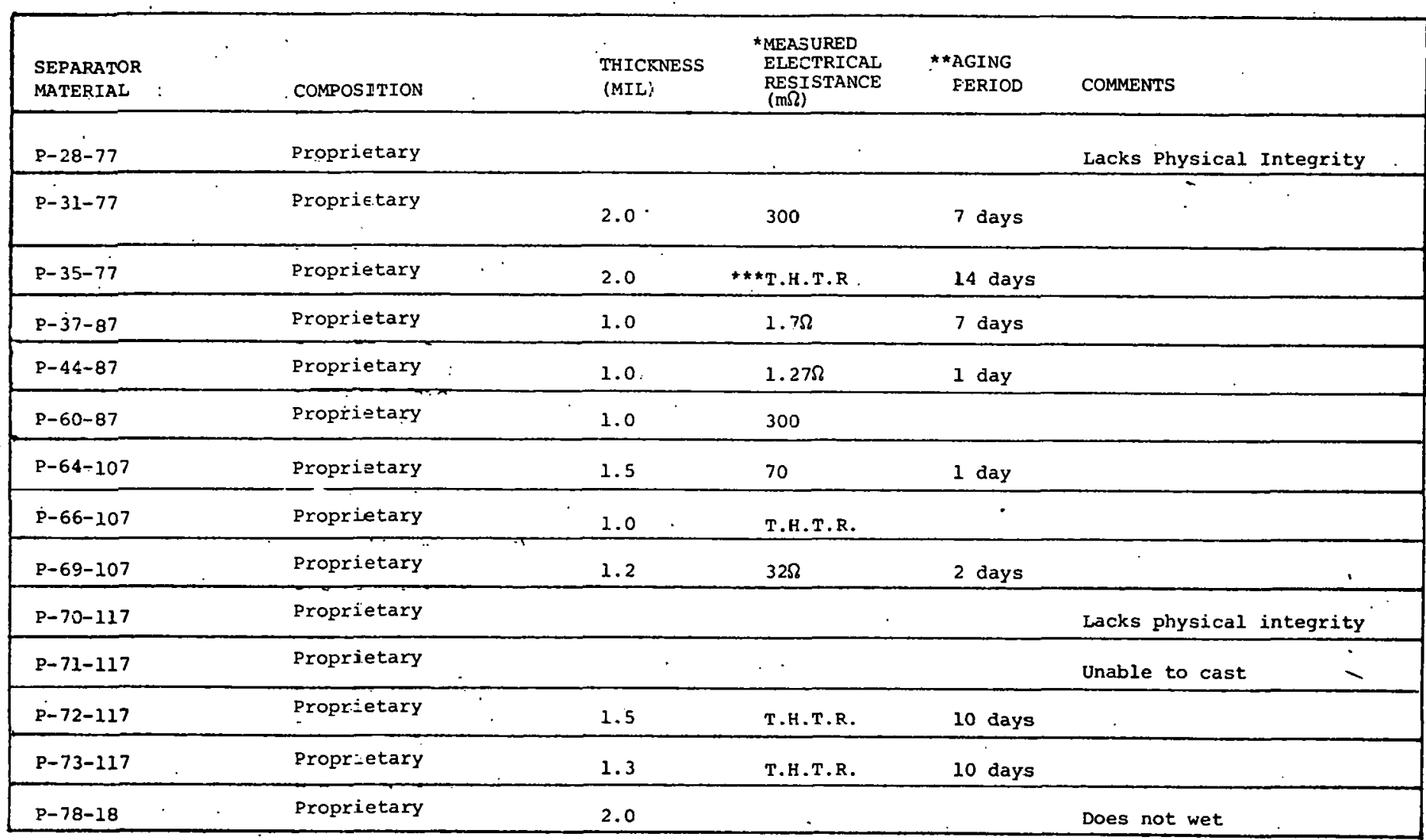

* For an area of $0.78 \mathrm{in}^{2}$

** Prior to test

$\star \star \star$ Resistance too $\mathrm{hlgh}$ to read 
TABLE I

PHYSICAL FROPERTIES OF SEPARATOR MATEFIALS

(Continued)

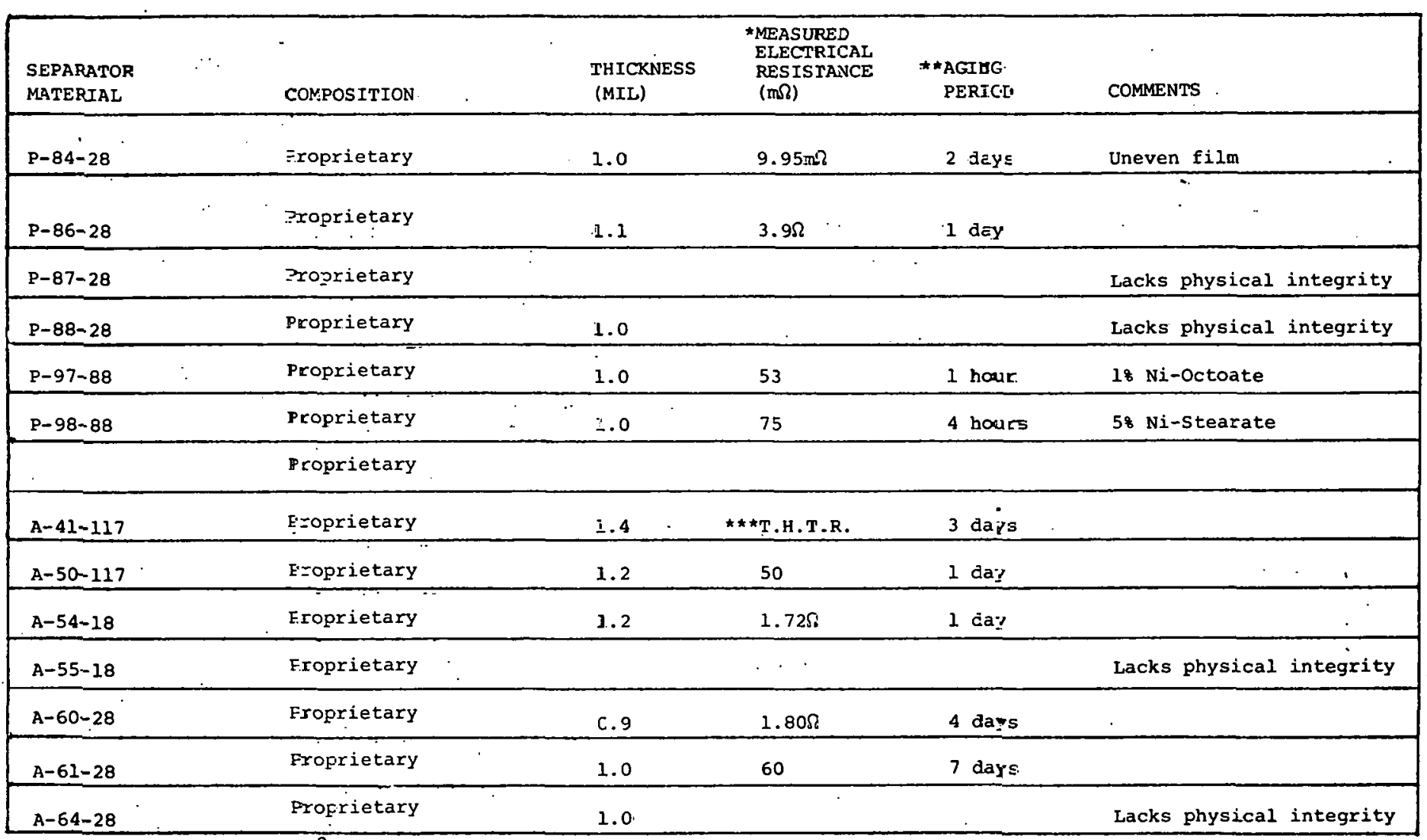

* For an area of $0.78 \mathrm{in}^{2}$

* Prior to test.

$\star \star *$ Resistance too high to read 
TABLE I

PHYSICAL PROPERTIES OF SEPARATOR MATERIALS

(Continued)

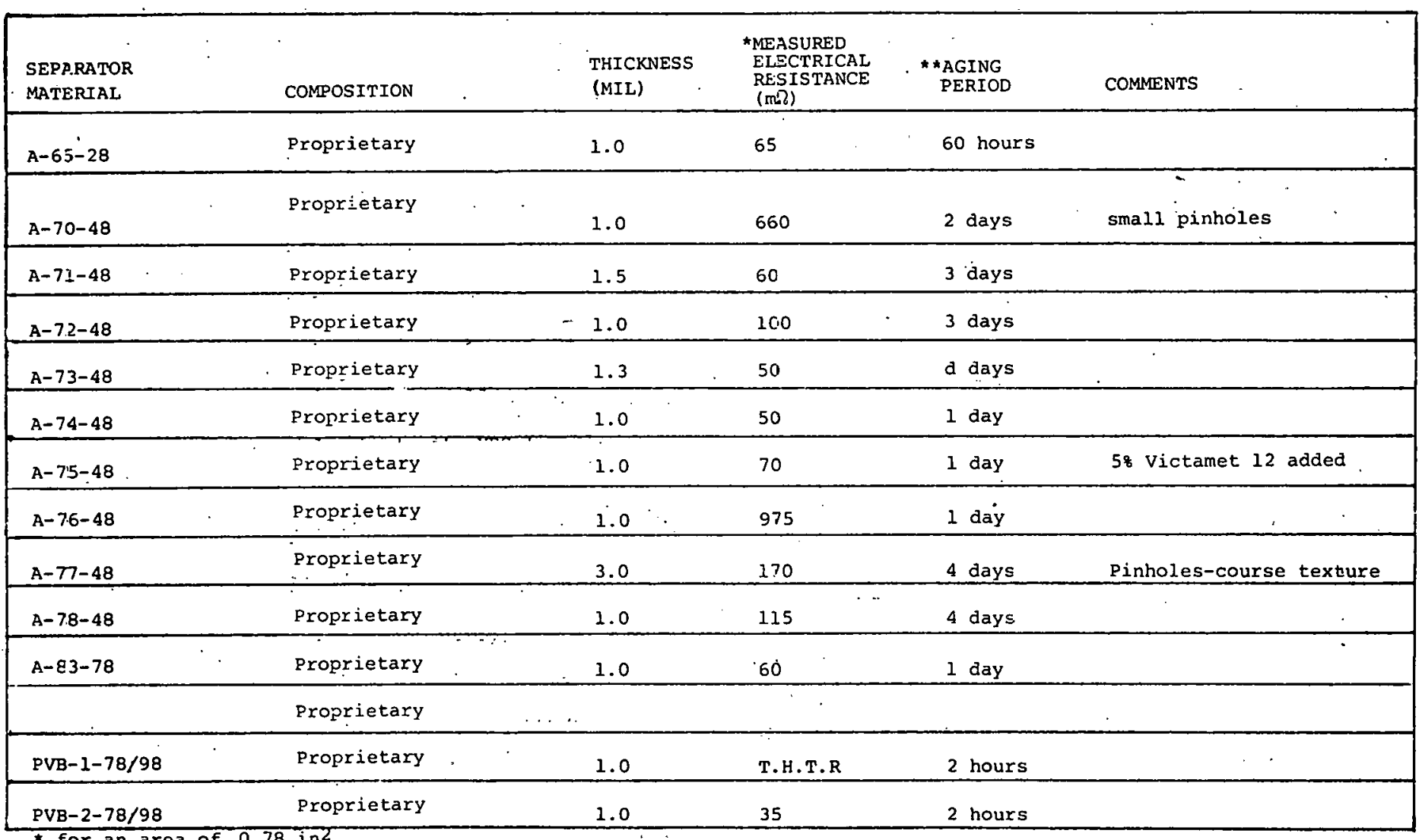

* for an area of 0.78 in ${ }^{2}$

**prior to tast

**electrical resistance too high to read 
TABLE I

PHYSTICAL PROPERIIES OF SEPARATOR MATERIAIS

(Concluded)

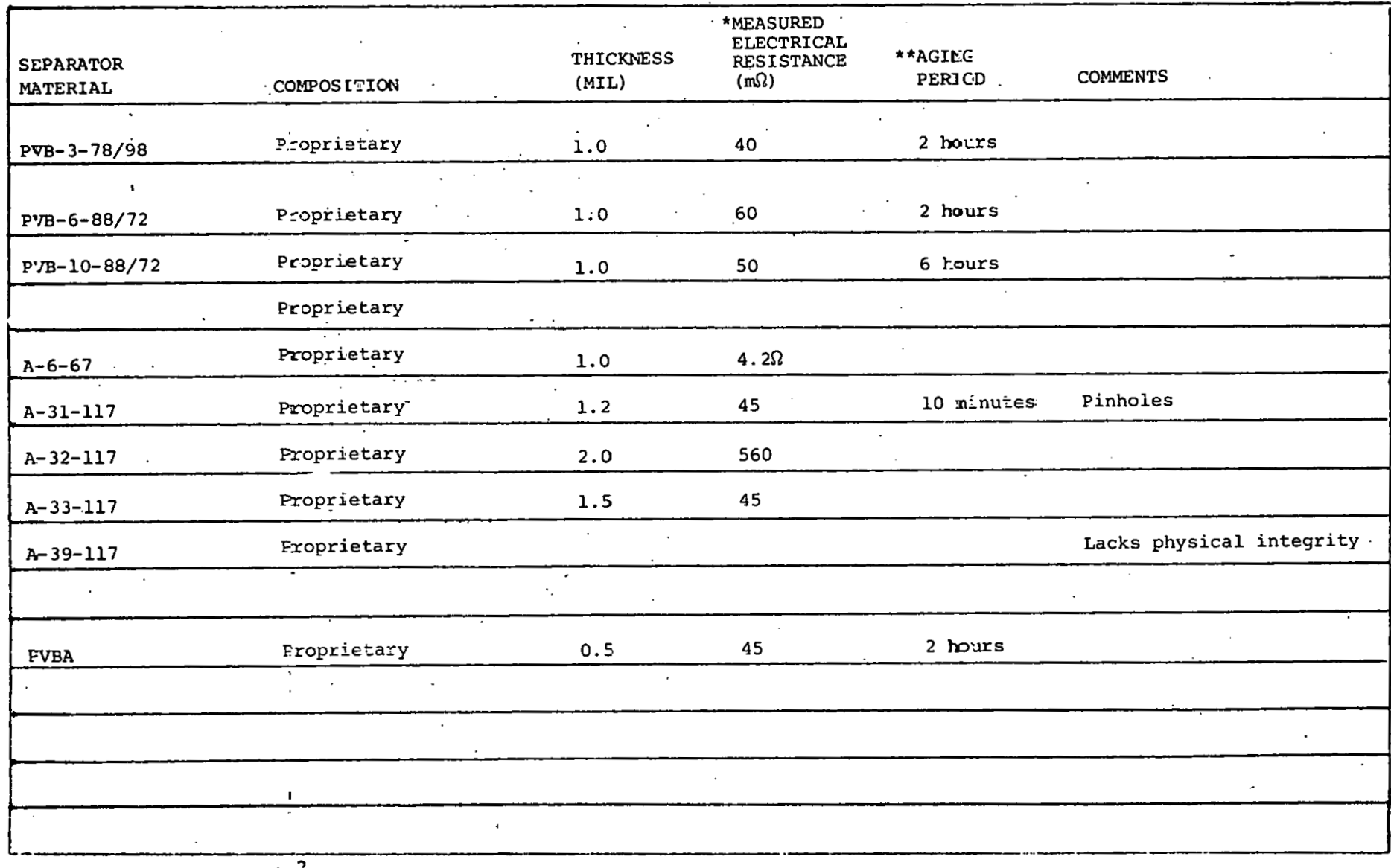

*for an area of 0.78 in $^{2}$

**prior to tes: 
TAELE II

AVERAGE PARTICLE SIZE AND CHEMICAL STABILITY OF FILLERS

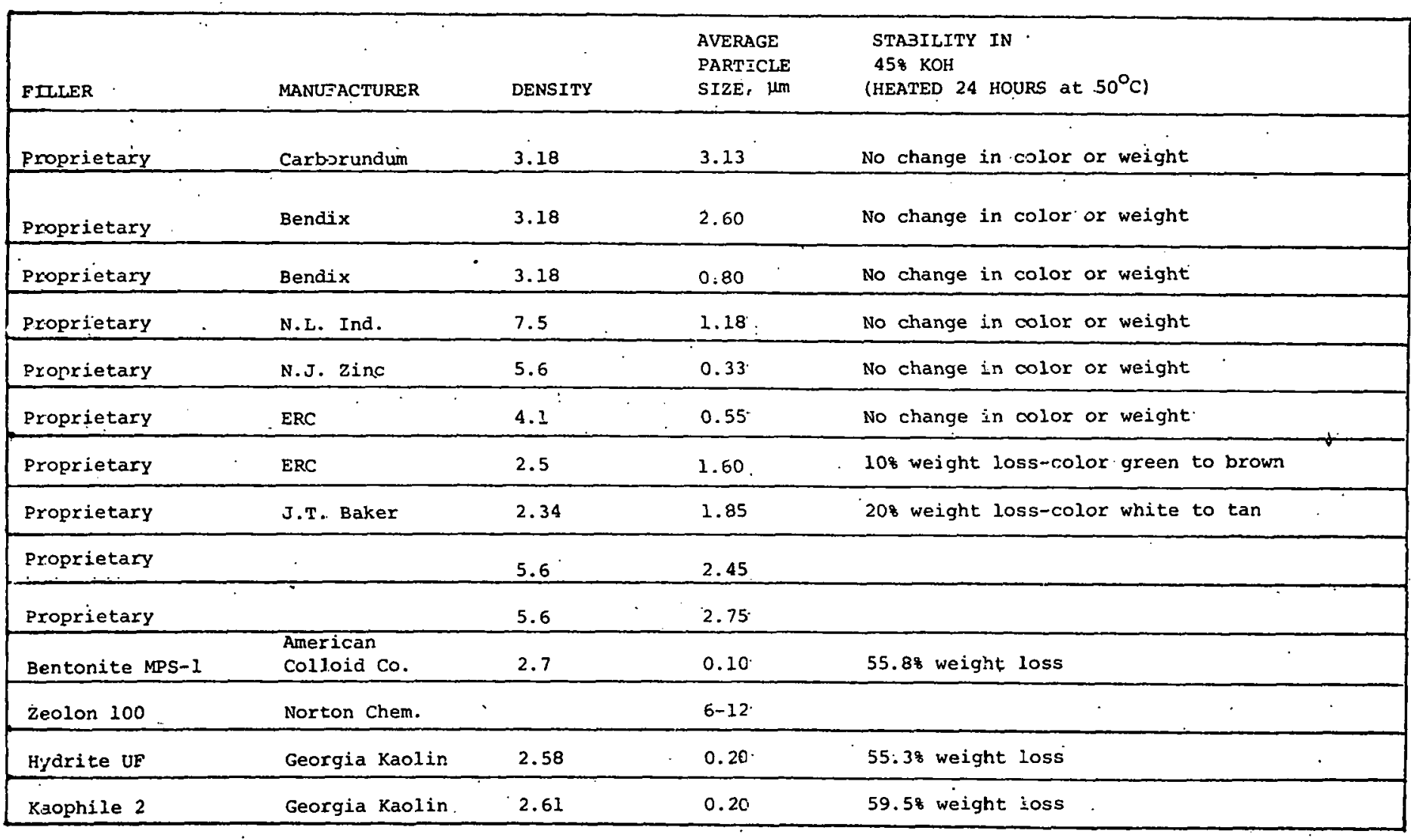


TäBLE II (Concludec)

AVERAGE PARTICLE SIZE AND CHEMICAL STABILITE OF FILLERS

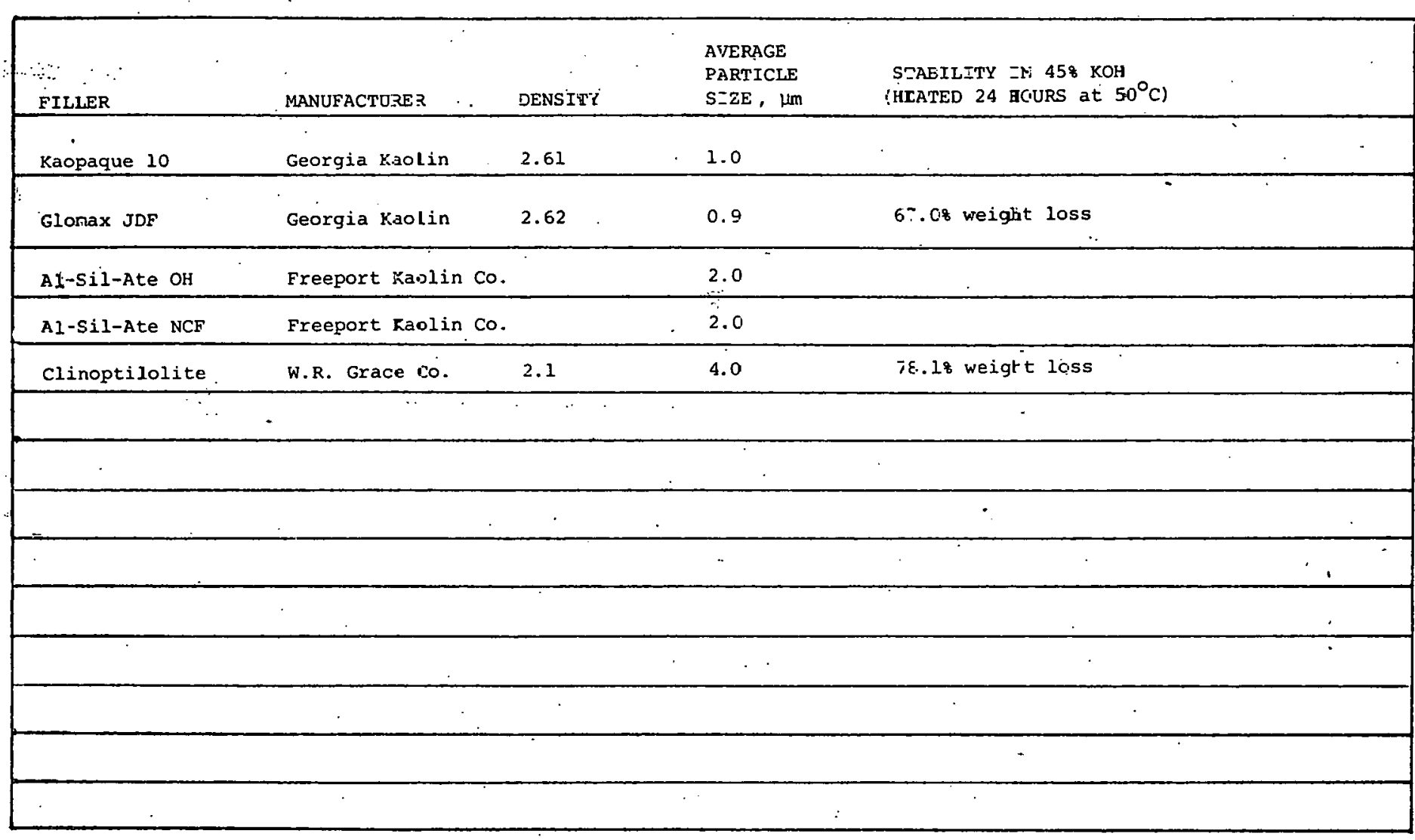


Due to the absorptive properties of hydrates and ion exchange capability of clays, a number of clays were evaluated as fillers in inert plastic films. Clays such as Kaolin, Bentonite, Zeolite and clinoptilolite were incorporated up to a $50 \%$ ratio by weight. The clays, which consist chiefly of aluminum silicate, differ greatly in crystalline structure and physical properties according to type and particle size. Particle size and chemical stability data for these clays is contained in Table II.

Four basic types of Kaolin were used (in the smallest particle sizes available) and they are designated as Hydrite U.F., (hydrated form), Glomax JDF (calcined form), Kaophile 2 (surface modified form) and Kaopaque 10 (delaminated form). Two other hydrated kaolins are Al-Sil-Ate $O H$ and Al-Ail NCF. Natural Bentonite, which is a mineral montmorillonite, is a special form of clay. It swells only slightly in strong alkaline solution and is known to have an intercalcated water.

Zeolites having the mineralogical name mordenite have a unique crystalline structure and provide remarkably uniform intercrystalline pores. Zeolon 100 molecular sieve is a synthetic zeolite which is know for strong alkaline resistance. In addition to chemical stability, zeolon 100 has pores which can absorb molecules larger than $5 \AA$ in diameter.

All the plastic/clay formulations cast uniform and strong films except for bentonite. The film with bentonite is uniform but not strong and pinholes or large pores are visible. After 2 to 3 days in $45 \% \mathrm{KOH}$ at $500^{\circ} \mathrm{C}$ the electrical resistance of these materials reached a minimum value of around $50 \mathrm{~m} \Omega / \mathrm{in}^{2}$. The plastic/bentonite film, however, showed a resistance of $660 \mathrm{~m} \Omega$ after 2 days. In addition, during wetting rate tests the resistance of this film increased while readings decreased silowly for other films at room temperature. Although bentonite swells less in $\mathrm{MeOH}$ than in water, it swells sufficiently in the former to shrink back when the film is dried, leaving fine pores in the film. During the wetting test in $45 \% \mathrm{KOH}$, the filler appeared to have expanded to maximum volume and all pores were closed up.

A common problem with plastic/clay formulations is the presence of large clumps which breakdown in the alkaline environment of the cell leaving pinholes which lead to dendritic shorting. A leading formulation at this time is designated $A-61$ and is composed by weight of $70 \%$ plastic and $30 \% \mathrm{Al}_{2} \mathrm{O}_{3}$. Bata for the various plastic formulations is contained in 'l'able I.

\subsection{Celgard As support}

Chemically stable celgard (Type 3400) film has pores which are too large to stop dendritic migration. In order to control pore size, ERC plastic, nylon and polyox formulations as well as $\Lambda P N$ and PNF were roated onto the celgard. 
TABLE III

PHYGICAL PROPERTIES OF SUPPORTED FILM

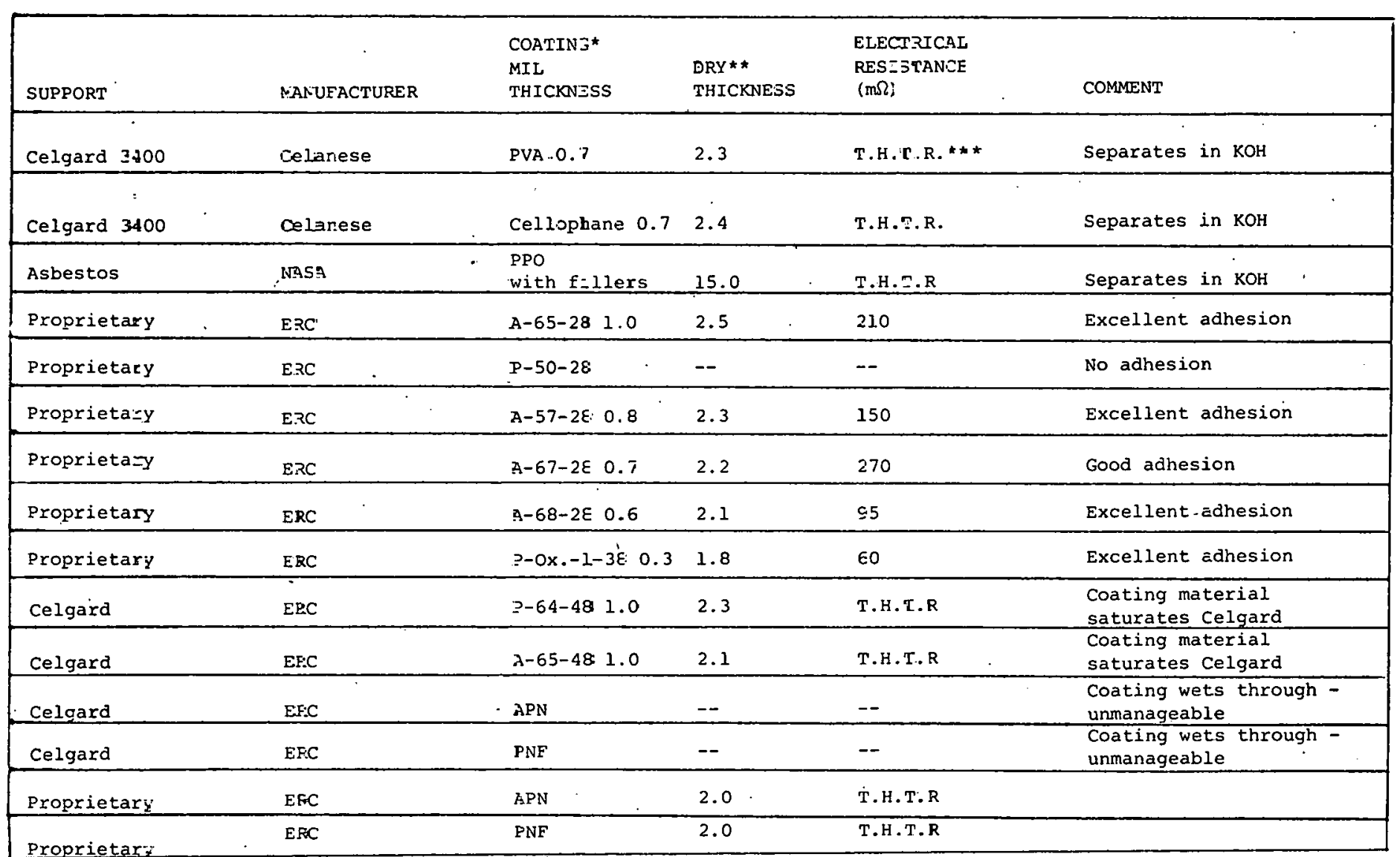

*dry thickness of coating $*$ dry thickness of separator material after coating

***electrica resistance too high to read 
All of the above formulations wet through the Celgard producing films which were quite stiff except the APN and PNF coatings which remained tacky and unmanageable. Table III summarizes the characteristics of the supported films.

\subsection{Screening Tests}

A primary function of this separator program is the evaluation of commercially-available separators, as well as the development of tests to better characterize ERC separator materials and components.

\subsubsection{Evaluation of Fillers}

A number of inorganic materials were characterized with relation to particle size, specific gravity and chemical stability in $45 \% \mathrm{KOH}$ at $50^{\circ} \mathrm{C}$. Table II shows the average particle size and chemical stability of some fillers under these conditions. The chemical stability study of very fine particle fillers created some problems during filtration or centrifuging. The particles went through the fritted sintered glass filter. Alternatively, when standard filter paper was used, it was not stable enough to filter the particles in the strong alkaline solution. In addition, centrifuging could not precipitate these fine particles.

\subsubsection{Evaluation of Separator Materials}

Screening tests for commercial and ERC manufactured separator materials include the following:

A. Chemical Stability

Separator materials are desiccated, weighed and soaked in $45 \% \mathrm{KOH} / 0.1 \mathrm{~N}-\mathrm{KMnO}_{4}$ solution at 500C. After appropriate time intervals samples are removed, washed free of electrolyte, dried, desiccated and weighed to determine weight loss.

The chemical stability measurements of plastic/clay materials showed $50 \%$ weight loss after they were heated at $500^{\circ} \mathrm{C}$ in $45 \% \mathrm{KOH}$ solution for three days. As $100 \%$ plastic film controls showed no weight loss, this indicates that $100 \%$ of the fillers were leached out of the film. When the stability measurements of fillers were carried out in the same manner by using 3 gram samples in $125 \mathrm{cc} \mathrm{KOH}$ solution, only $18 \%$ of weight loss was measured. When l-gram samples in $100 \mathrm{cc} \mathrm{KOH}$ were used, weight loss increased to 58.5\%. The solubility of these clays in $45 \% \mathrm{KOH}$ appeared to be lower than the concentration mentioned above $(1 \mathrm{gm} / 100 \mathrm{cc})$ and yet high enough to leach $100 \%$ of the fillers from the separator materials.

B. Porosimetry Analysis

Three separator materials (commercial PVA, P-50\& P-64) were subjected to a pore volume, size and distribution study as determined by the mercury penetration method. Sample P-64 consists of $90 \%$ volume plastic and $10 \%$ volume soluble filler 
PORE DIAMETER FOR $130^{\circ}$ CONTACT ANGLE, $\mu \mathrm{ma}$

In

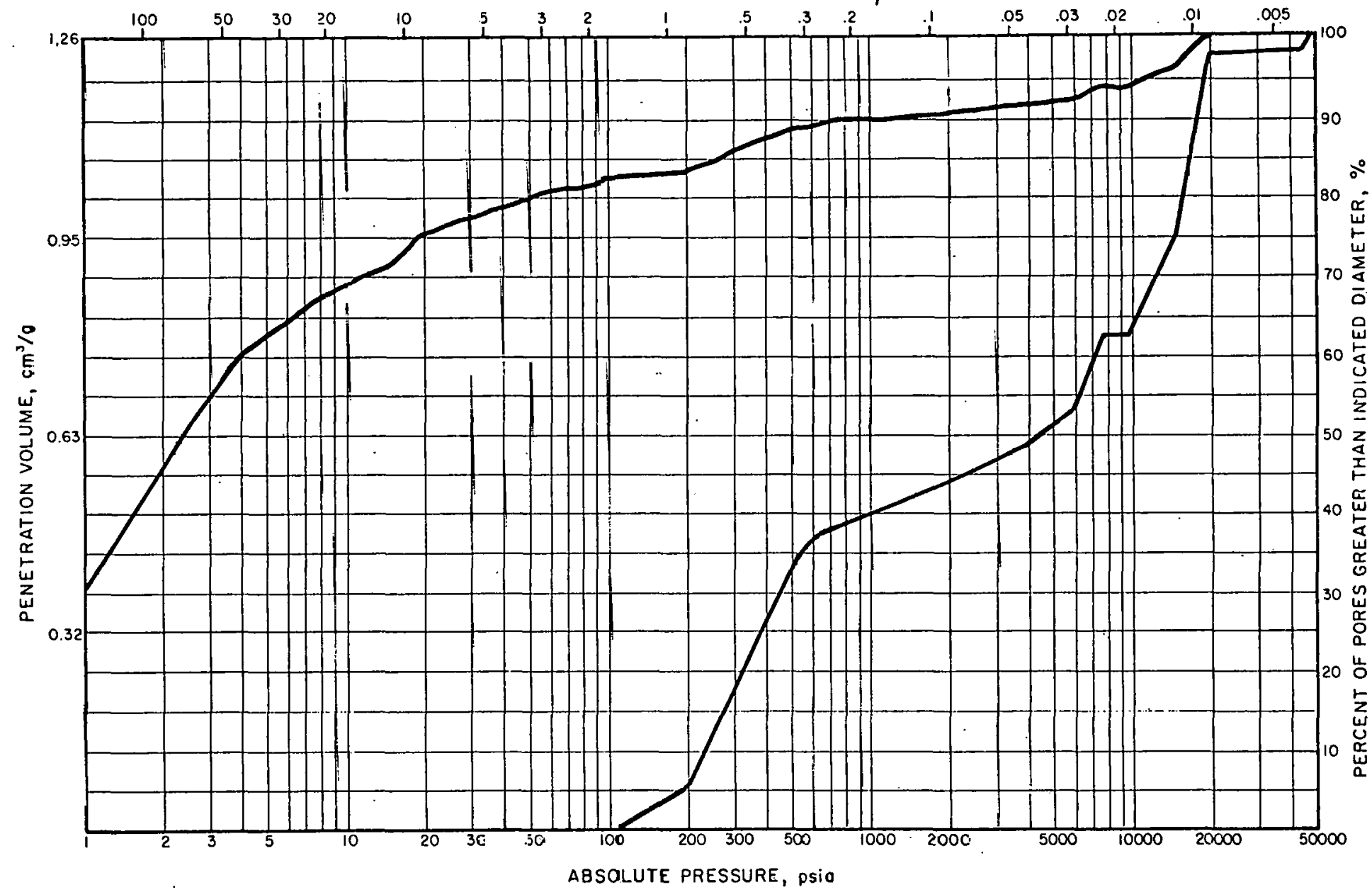

FIGURE 1

PORE DISTRIBUTION. CURVE OF SAMPLE P-64 


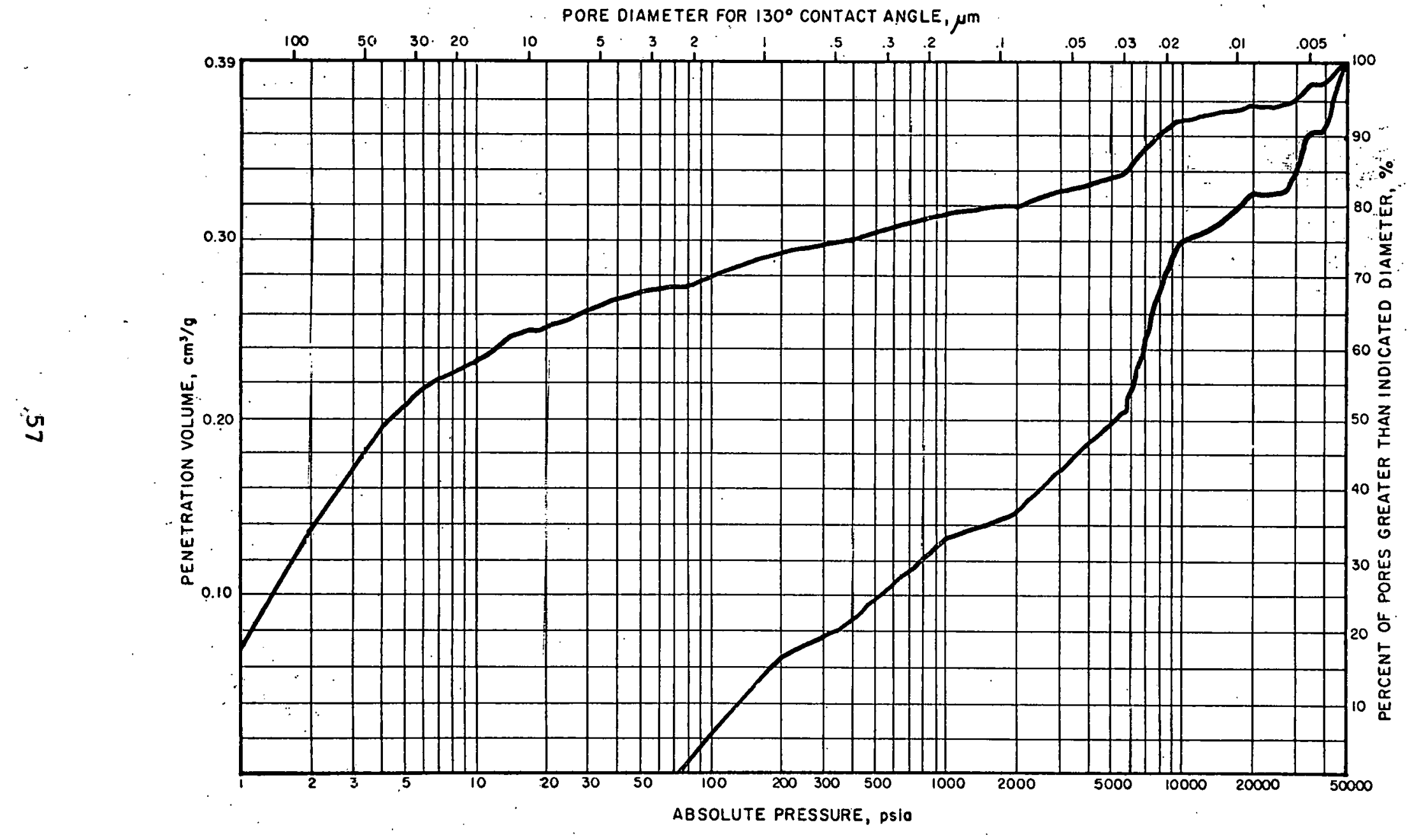

FIGURE 2

PORE DISTRIBUTION CURVE OF SAMPLE P-5O 


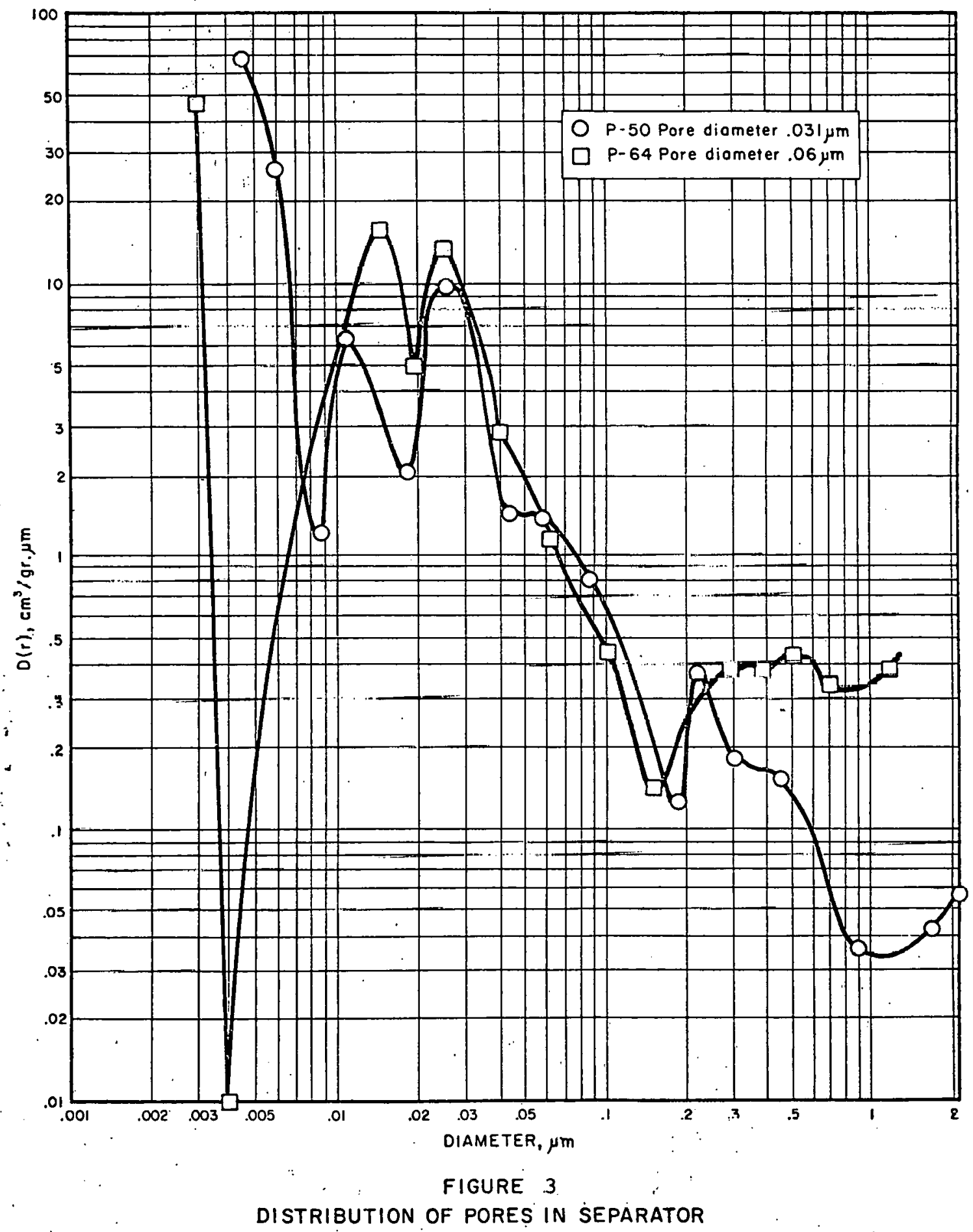




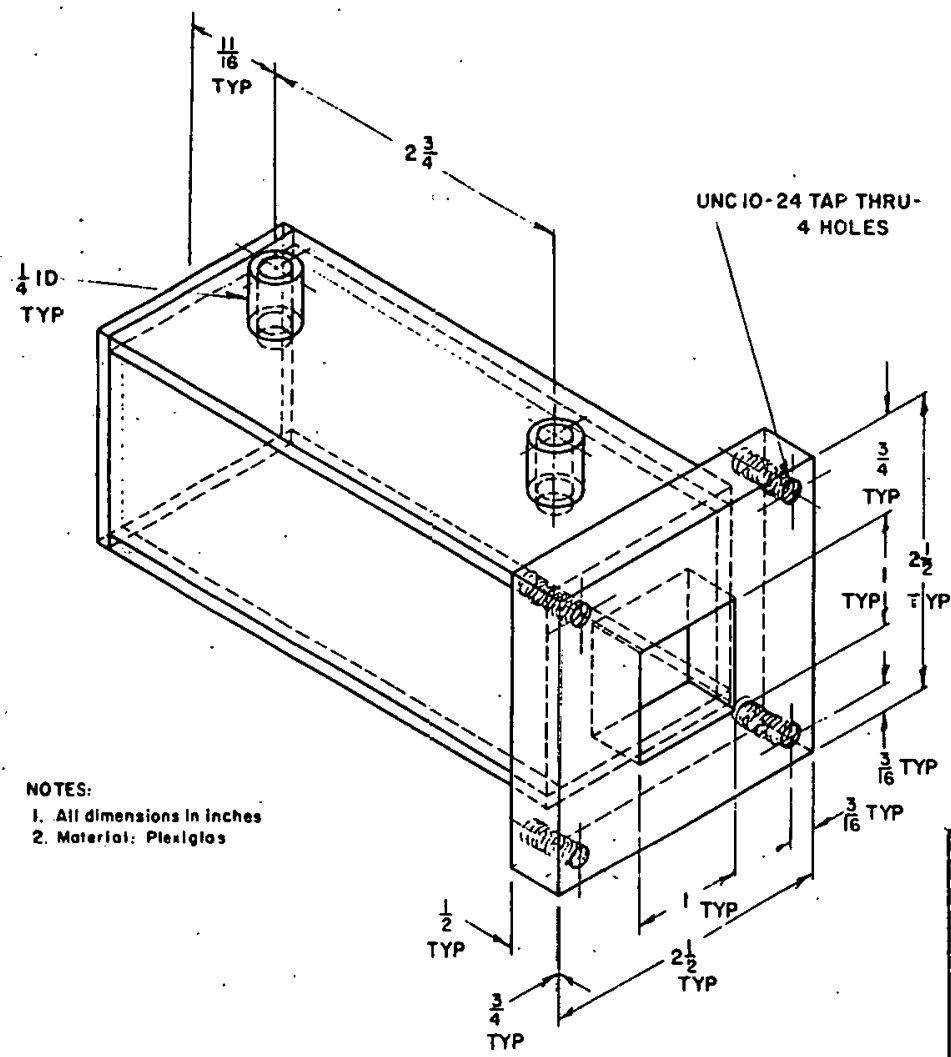

FIGURE

DIFFUSION APPARATUS

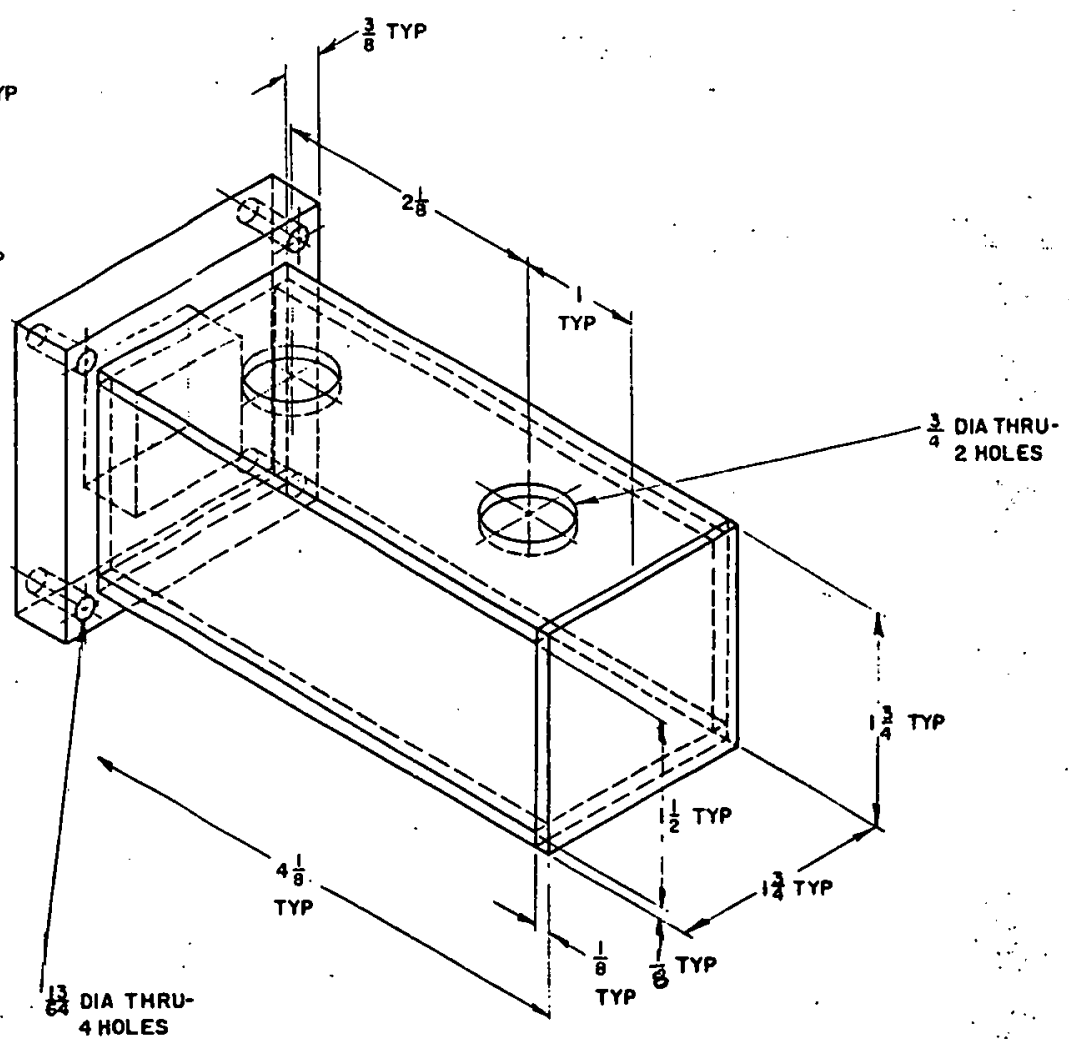


which were leached out from the film before the analysis was conducted. Sample P-50 has $76 \%$ plastic, $7.5 \%$ soluble fillers and 16.5\% insoluble fillers based on volume. The porosity of a sample of commercial PVA film could not be determined by mercury intrusion. Two sets of data for each sample are summarized in Table IV and pore size distribution curves are shown in Figures 1 and 2. Analysis of the data in Figures 1 and 2 yields distribution curves plotted in Figure 3. These resulting distribution curves represent the volume of pore for a given radius.

TABLE IV
Summary of Porosimetry Analyses on $P-64 \&$ \& -50

\begin{tabular}{lcc}
$\begin{array}{l}\text { Separator } \\
\text { Material }\end{array}$ & $\begin{array}{l}\text { Net Pore } \\
\text { Volume (cc/g) }\end{array}$ & $\begin{array}{c}\text { Avg. Pore Diameter } \\
\text { (microns) }\end{array}$ \\
\hline P-64 & 0.1808 & 0.06 \\
$P-54$ & 0.2266 & 0.037 \\
$P-50$ & 0.1239 & 0.031 \\
$P-50$ & 0.1536 & 1.8
\end{tabular}

Although the data recorded is probably the best we can expect by mercury porosimetry. considering the type of materials (flexible plastic membranes), this method is not accurate for materials with pores smaller than $300 \AA$. A few other possible methods to study the porosity for submicron pores could be by Transmission Electron Microscopy and by nitrogen adsorption and desorption isotherms.

C. Electrolyte Diffusion Rate Measurements

'l'he permeability of a membrane to an electrolyte is useful for characterizing separator materials and it can be expressed by means of the electrolyte diffusion rate.

A design for diffusion rate test cell is shown in Figure 4 . The diffusion rate can be determined by measuring the hydroxyl ion concentration charqe of the solution on the rilute side of the membrane, per unit time, per unit area of sample. The hydroxyl ion concentration can be obtained by measuring the $\mathrm{pH}$ of the solution directly using a pH meter. A procedure measuring the electrolyte diffusion rate was established using a similar method described by E.L. Harris.

$45 \% \mathrm{KOH}$ solution (11.67M) was used on the strong solution side and deionized water on the low concentration side of the separator material. It was found that the effect of mixing time in the dilute side of the cell was negligible with respect to concentration gradient as long as the concentration gradient was mixed adequately before measuring $\mathrm{pH}$. The diffusion rate valve can also be used to estimate the upper limiting current densities of the separator in the batteries. 


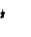

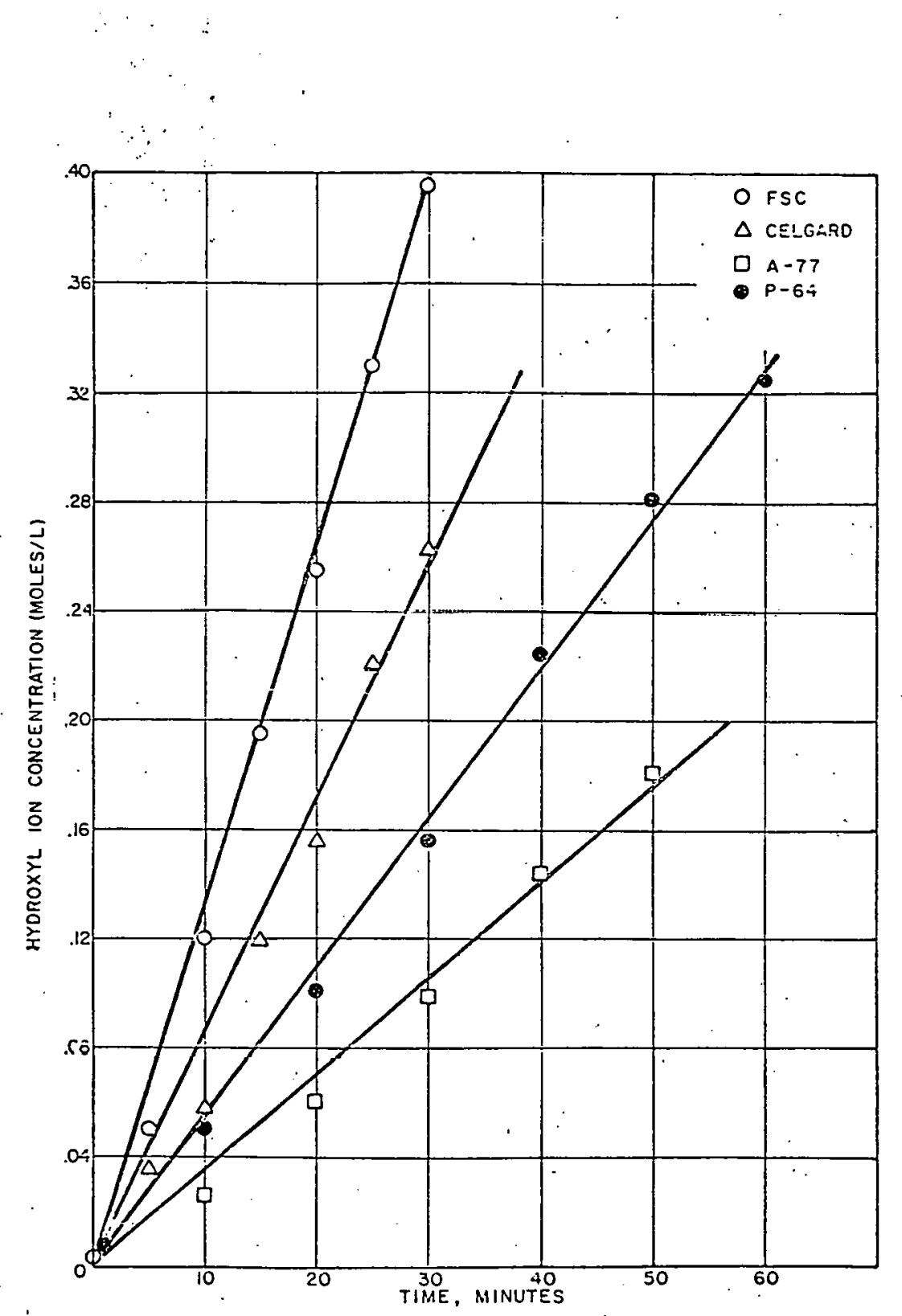

Hydroxyl Ion Diffusion Through Various Separators

FIGURE . 5 
TABLE V

TYPICAL DIFFUSTON DATA AND CALCUEATTORS

SAMPLE: F.S.C. (Jnion Carbide)

for 24 hrs. prior to measu=ement

\begin{tabular}{|c|c|c|c|}
\hline IME & pH & $\mathrm{POH}$ & $\mathrm{OH}^{-}$ \\
\hline 0 & 11.40 & 2.60 & $0^{02^{-? .2 .60}}$ \\
\hline 5 & $12.7 \mathrm{C}$ & 1.30 & $-6^{-1.30}$ \\
\hline 10 & 13.09 & 0.91 & $=6^{-91}$ \\
\hline 15 & 13.29 & 0.71 & $=c^{-.71}$ \\
\hline 20 & 13.41 & 0.59 & $=c^{-.59}$ \\
\hline 25 & 13.52 & 0.48 & $=c^{-.48}$ \\
\hline 3 & 13.60 & 0.40 & $=c^{-.40}$ \\
\hline
\end{tabular}

Area 0 sample $=.785$ in 2

Voluma of Jilute eide $=14 \mathrm{ccc}$. of wCak side $=0.1 .111_{2} 0$

Mixing Cendizior $=2$ minites stirring

minjes stirring
minute rest before measurement

\begin{tabular}{|c|c|c|}
\hline${ }^{\mathrm{a} \mathrm{OH}}$ & ${ }^{\mathrm{a}}$ OII mole/t & $\frac{\lambda c}{\Lambda t} \cdot \operatorname{mole} / \mathrm{t}$ \\
\hline $10^{-3} \times 10^{.40}$ & $2.522 \times 10^{-3}$ & \\
\hline $10^{-2} \times 10^{.70}$ & $5.0 \div 2 \times 10^{-2}$ & $1.761 \times 10^{-2}$ \\
\hline $10^{-1} \times 10^{.09}$ & $1.23 \times \equiv 0^{-2}$ & $.7288 \times 10^{-1}$ \\
\hline $10^{-1} \times 10^{.29}$ & $1.95 \times \mathrm{ia}^{-1}$ & $.7200 \times 10^{-1}$ \\
\hline $10^{-1} \times 10^{.41}$ & $2.5: \times 10^{-1}$ & $.620 \times 10^{-1}$ \\
\hline $10^{-1} \times 10^{.52}$ & $3.3 \pm 1 \times 10^{-1}$ & $.741 \times 10^{-1}$ \\
\hline $10^{-1} \times 10^{.60}$ & $3.9 \equiv 1 \times 10^{-1}$ & $.670 \times 10^{-1}$ \\
\hline
\end{tabular}

$F E U X=\frac{\Delta H}{\Delta \cdot t}=\frac{\Delta C}{L t} \times \frac{V}{A}=\frac{.70 \times 10^{-1} \& .140}{5 \times .785}=2.496 \times 10^{-3} \mathrm{~mole} / \mathrm{mirmin}^{2}$

$N=$ rate of material transfer

$t=$ time interva

$z=$ Area of sample

$\zeta=$ lolume of diJute solution

$c=$ Concentratior of hydroxide ions 
TABLE VI

SINGLE ELECTRODE CELL CYCLE LIFE SUMMARY

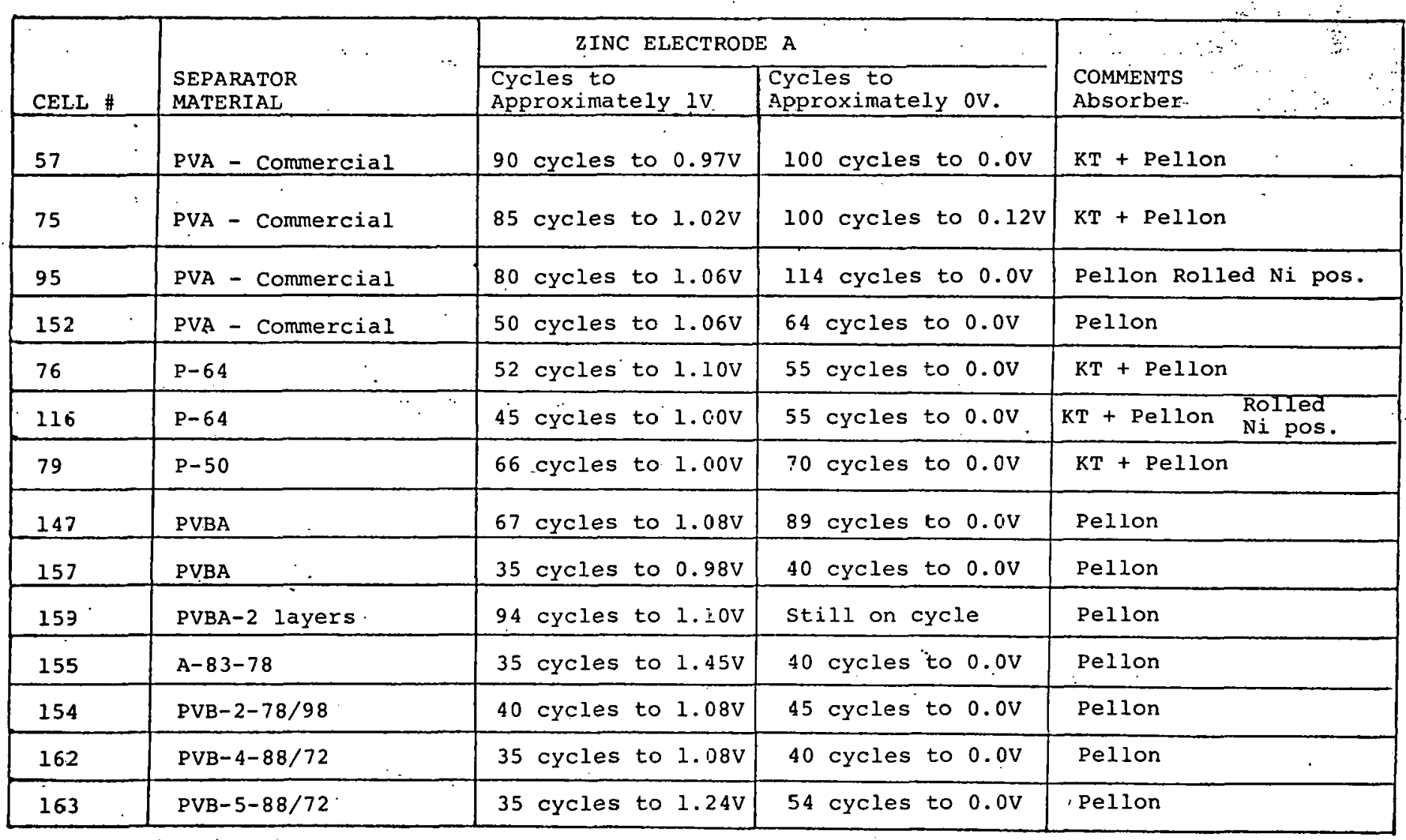


TABLE V VI

SINGIE ELECTRODE CELL CYCLE LIFE EUMMARY (Continued:

\begin{tabular}{|c|c|c|c|c|}
\hline \multirow[b]{2}{*}{ CELL \# } & \multirow{2}{*}{$\begin{array}{l}\text { SEPARATOR } \\
\text { MATERIAL }\end{array}$} & \multicolumn{2}{|l|}{ ZINC ELECTRODE B } & \multirow{2}{*}{$\begin{array}{l}\text { COMMENTS } \\
\text { Absorber }\end{array}$} \\
\hline & & $\begin{array}{l}\text { Cycles to } \\
\text { F.pproxirately } 1 \mathrm{~V} .\end{array}$ & $\begin{array}{l}\text { Cycies to } \\
\text { Approximately or. }\end{array}$ & \\
\hline $63^{\circ}$ & PVA & 39 cycles to $1.05 \mathrm{~V}$ & 108 cycles to 0.0 : & $\mathrm{KT}+$ Pellon \\
\hline 85 & PVA - Comne =cial & L05 cycles to $1.00 \mathrm{~V}$ & 128 cycles to $3.0 \mathrm{~V}$ & Pellon \\
\hline 111 & PVA - Comnercial & 208 cycles to $0.9 \mathrm{~V}$ & 242 cycles to $0.0 \mathrm{~V}$ & Pellon \\
\hline 126 & PVA- 2 layers & 150 cycles to $1.10 \mathrm{~V}$ & 161 cycles to $0.0 \mathrm{~V}$ & Pellon \\
\hline 64 & $P-50$ & 220 cycles to 1.234 & 135 cycles to $0.0 \mathrm{~F}$ & $\mathrm{KT}+$ Pellon \\
\hline 124 & $p-50-2$ layers & I68 cycles to $1.30 \mathrm{y}$ & 203 cycles to 0.08 & Pellon \\
\hline 87 & $\mathrm{P}-64$ & 55 cycles to $1.13 \mathrm{~V}$ & 61 cycles to $0.0 \mathrm{~V}$ & $\mathrm{KT}+$ Pellon \\
\hline 113 & $\mathrm{P}-64$ & I81 cycies to $1.08 \mathrm{~V}$ & 195 cycles to $0.0 \mathrm{~V}$ & Pelion \\
\hline 119 & $A-67$ & $4 \mathrm{C}$ cycles to $1.50 \mathrm{~V}$ & 150 cycles to $0.0 \mathrm{~V}$ & Pellon \\
\hline $122^{\circ}$ & $A-67$ & 98 cycles to $1.02 \mathrm{~V}$ & 99 cycles to $0.0 \mathrm{~V}$ & Pelion \\
\hline 125 & A-67-2 layers & $i 40$ cycies to 1.264 & 142 cycles to 0.. or & Pellon \\
\hline 120 & $A-61$ & $\Xi 20$ cycies to 1.314 & 132 cycles to o..ov & Pellon \\
\hline 137 & S.A.C. EAHT 2016 & E. 3 cycles to $1.08 \mathrm{~V}$ & 100 cycles to 0.05 & Pellon \\
\hline 148 & PVBA & 145 cycles to 1.15 . & 155 cycles to $0.0 \mathrm{~V}$ & Pellon \\
\hline
\end{tabular}


TABLE VI

SINGLE ELECTRODE CELL CYCLE IIFE SUMMARY

(Concluded)

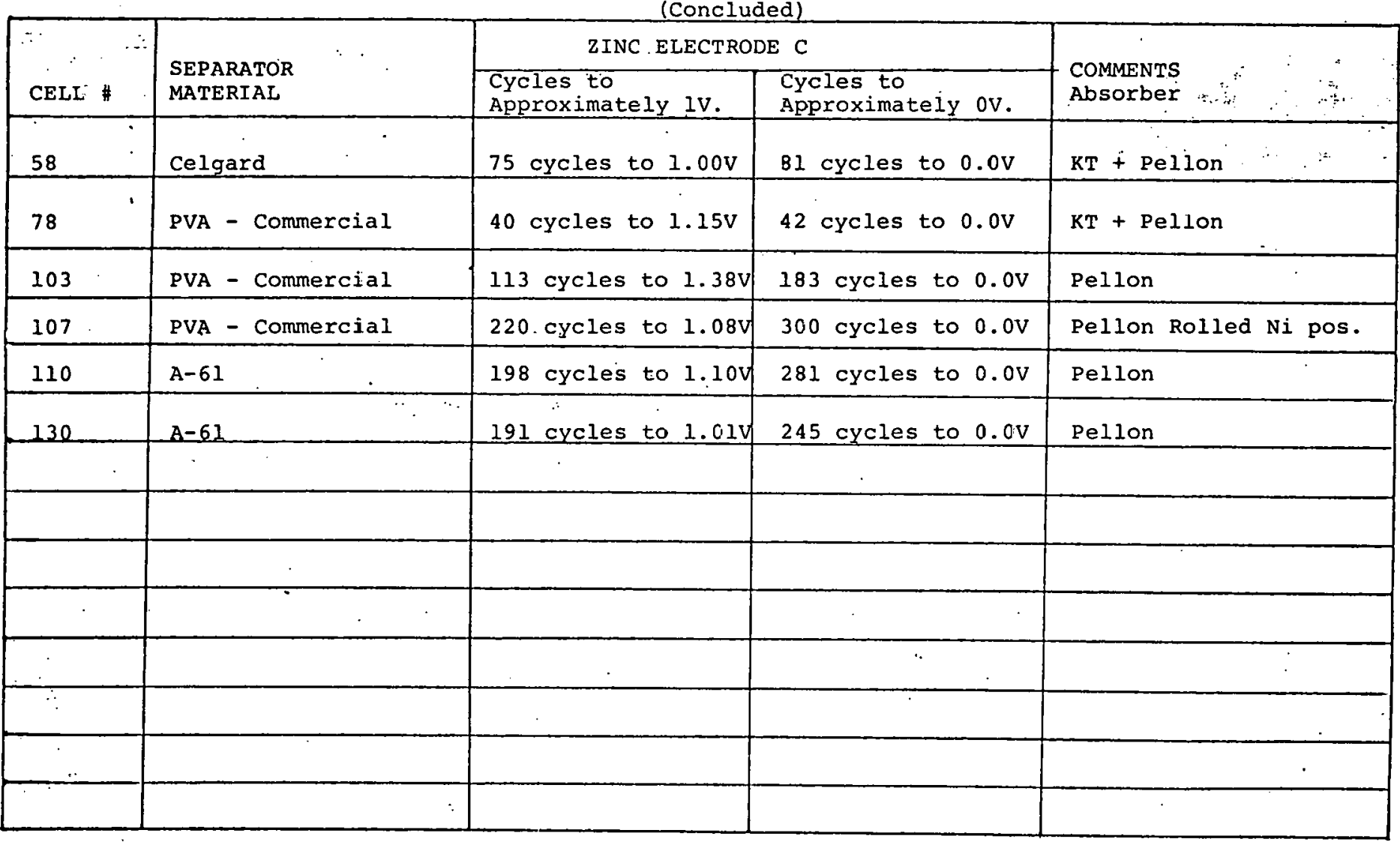


Figure 5 illustrates the relationship between $\mathrm{OH}^{-}$concentration and the diffusion rate for 4 different types of separators. Details of diffusion data and calculations are amplified in Table V.

D. Electrical Resistance Measurement

These measurements were carried out by measuring the voltage drop between two reference electrodes with and without direct current through the material in $45 \% \mathrm{KOH}$ solution. The area of the sample being measured is $0.78 \mathrm{in}^{2}$.

Electrical resistance for the separator materials is summarized in Table $I$.

In general, clay filled separator films showed low electrical resistance, ranging from $40 \mathrm{~m} \Omega / \mathrm{in}^{2}$ to $80 \mathrm{~m} \Omega / \mathrm{in}^{2}$, except for the plastic/bentonite film, which is over $500 \mathrm{~m} \Omega / \mathrm{in}^{2}$.

E. Zinc Penetration l'est - Single Electrode cell Test

Accelerated zinc penetration tests were carried out in cells which have been constructed with one layer of separator to test the zinc stopping ability under severe conditions where rapid failure is induced. The positive electrodes are 2 full, sintered nickel electrodes and the nogative elcctrodc 3 are roll bonded zinc oxide with various additives.

Type of zinc electrode made a significant difference in the life of the single electrode cells. Table VI summarizes cycle life for different separators and three zinc electrode combinations.

Not all separator materials have been evaluatod with the same zinc electrodes. As such results from this test are not fully comparable for this reason, graphs of discharge end voltages shown in Table VI are referenced as th 7 inr plertrodo composition and comparisons restricted to electrode types.

F. Tensile Strength Hang Test

observing changes in tensile strength over time at an air-electrolyte interface can give valuable information concerning chemical stability of a separator material. This is particularly important for comparing commercial PVA to filled plastic separators and other experimental materials, as the former cannot bc tested by means of weight change after soaking in $0.1 \mathrm{~N}-\mathrm{KMnO}_{4}: 45 \% \mathrm{KOH}$.

Figure $\overline{6}$ shows an incubator and representation nf the test set up. The incubator features a glass inner door to allow for observation of test units without disturbing test conditions. This permits a constant temperature vibrationfree environment.

SLrips of separator material 1/16" wide by 2 " long will be suspended in individual test tubes. Weights are con- .' structed from 304 S.S. and designed to provide a constant $300 \mathrm{lb} / \mathrm{in}^{2}$ force for cross sectional area of separator material. 


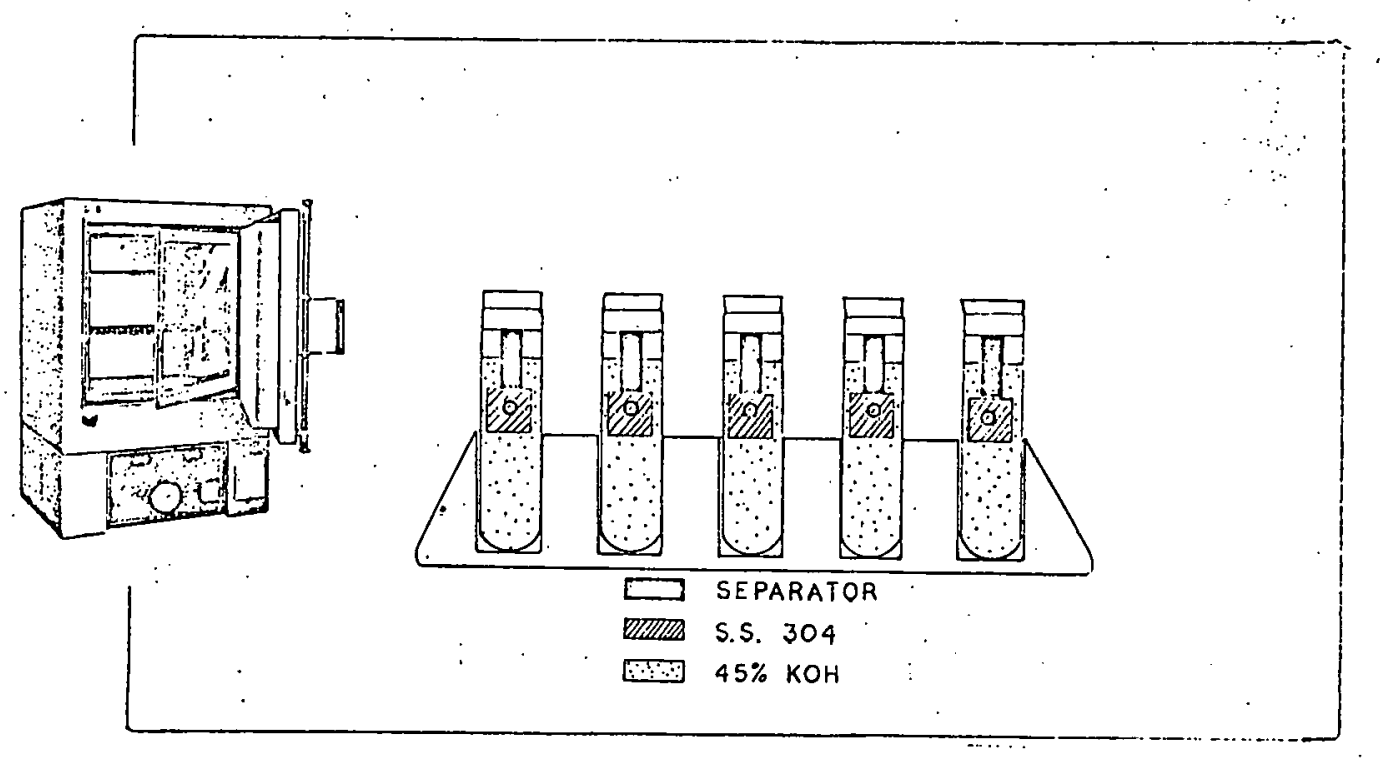

FIGURE 6. TENSILE STRENGTH HANGING TEST SET-UP 
45\% KOH will be filled to half the length of separator sample. Test units will be placed in the oven at $65^{\circ} \mathrm{C}$ and observed at regular intervals. Lengths of time until the separator degrades to the breakpoint will be recorded and averaged over a given number of samples. While 1/16" samples may be subject to flaws which would significantly alter individual tests, it is expected that averaging over a number of samples will provide a reasonable characterization of each separator. This data will provide a baseline for comparisons not available from present tests. 


\subsection{CONCLUSIONS}

During this period, several inorganic/organic separator compositions have been developed which are promising candidates for use in the nickel-zinc systems. These materials are filled and plasticized plastic P-64, PVBA and PVB.

Screening tests which include $\mathrm{KmnO}_{4}$ oxidation, electrolyte diffusion, electrolyte resistance, and hanging strength in $\mathrm{KOH}$ have been developed which provide good information concerning ultimate performance in cells.

Processing techniques have been scaled up to provide film continuously at the rate of 20-200 ft/hr. depending on the material.

Plans for the next 12 months include: the determination of performance of these materials in $250 \mathrm{Ah}$ size cells as well as the continuation of investigative efforts to improve the mass transport characteristics of these separators for sealed cells.

The on-going program will also include the investigation of new composite materials. 


\section{THIS PAGE}

\section{WAS INTENTIONALLY \\ LEFT BLANK}




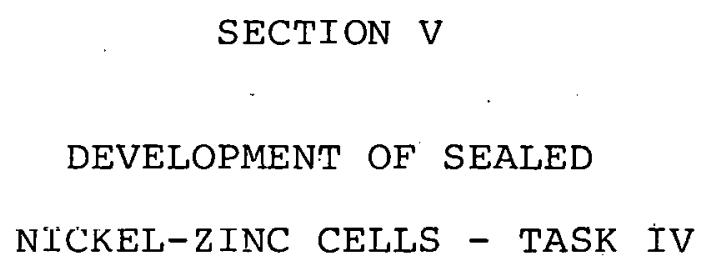




\subsection{INTRODUCTION}

- The goal of this phase of the ANL nickel-zinc research and development program will be to determine the feasibility of operating large size cells in a sealed condition.

Initial exploratory studies will be carried out in $20 \mathrm{Ah}$ size sealed cells to establish baseline construction and mode of operation parameters for cells containing various separator systems and zinc electrode additives. Cells containing both bonded and sintered nickel electrodes will also be fabricated.

The sealed cell investigation will include determination of rates of oxygen recombination, hydrogen generation, effect of electrolyte concentration and quantity, cycle life as a function of depth of discharge, and effect of constant current, moditied constant potential and pressure controllea types of charging.

The results of the 20 Ah cell study will then be used to design and construct $250 \mathrm{Ah}$ size cells for. further evaluation for electric vehicle application. 


\subsection{TECHNICAL DISCUSSION}

A total of thirty-six 20 Ah sealed cells are being built. Fourteen of the thirty-six cells have been completed and have begun testing. The discussion presented below details the work performed during the first five months of the project.

\subsection{Ah sealed Cell Designs}

The 36 sealed cells represent 14 different designs. The construction variables evaluated in these cells include separator system ( 5 levels), electrode additive ( 5 levels) and electrolyte concentration ( 4 levels). Sixteen of the cells contained sintered nickel electrodes which have been impregnated by a proprietary electrochemical method developed by ERC. The remaining 20 cells contain bonded $\mathrm{Ni}(\mathrm{OH})_{2}$ electrodes. Table I summarizes the construction variables for each group.

With regard to the negative plate additives, the $\mathrm{Tl}_{2} \mathrm{O}_{3}$ and $\mathrm{Pb} 0$ binary is a mercury substitute which has proven satisfactory in $850 \mathrm{Ah} \mathrm{Ag-Zn}$ cells which have been fabricated and tested under contracts for the Naval Sea Systems Command. The inert conductive layer plus $5 \% \mathrm{CdO}$ is a unique construction patented by ERC which has shown vastly improved cycle life in $40 \mathrm{Ah}$ Ag- $\mathrm{Zn}$ cells. Both types of negative plates also contain a small percentage of Teflon which serves as a binder permitting the material to be rolled into continuous sheets.

The five separator systems being evaluated are listed in Table I. A major problem in sealed cell design is that the nickel-zinc system requires a microporous separator system to inhibit dendrite growth shile larger pores are required for effective transport of oxygen for recombination.

Celgard is a wettable microporous polypropylene with pores that are about $200 \AA$ in width and $1000 \AA$ in length. This pore size is about 10-50 times greater than FSC or PVA.

The separator system containing 2 layers of FSC sandwiched between layers of Celgard was chosen as a control. The use of Celgard in this arrangement may provide some protection against oxidation of the FSC material.

Four electrolyte concentrations were selected to establish the optimum concentration for oxygen recombination and to learn how reduced zinc solubility in $25 \% \mathrm{KOH}$ affects cycle 1 ife and shape change. Figure 1 shows a schematic of the 20 Ah sealed cell.

\subsection{Test Regime}

The cells are filled with excess electrolyte and allowed to soak for 3 days. They are then put through two vented cycles consisting of charging at the $c / 16$ rate and discharging at $C / 2$ to 1.2 volts. After charging a third time at $C / 16$, the cells are drained of all free electrolyte and sealed, followed by a discharge at $\mathrm{c} / 2$ to 1.2 volts. 
TABLE I

20 Ah jealed Cell Construction Variables

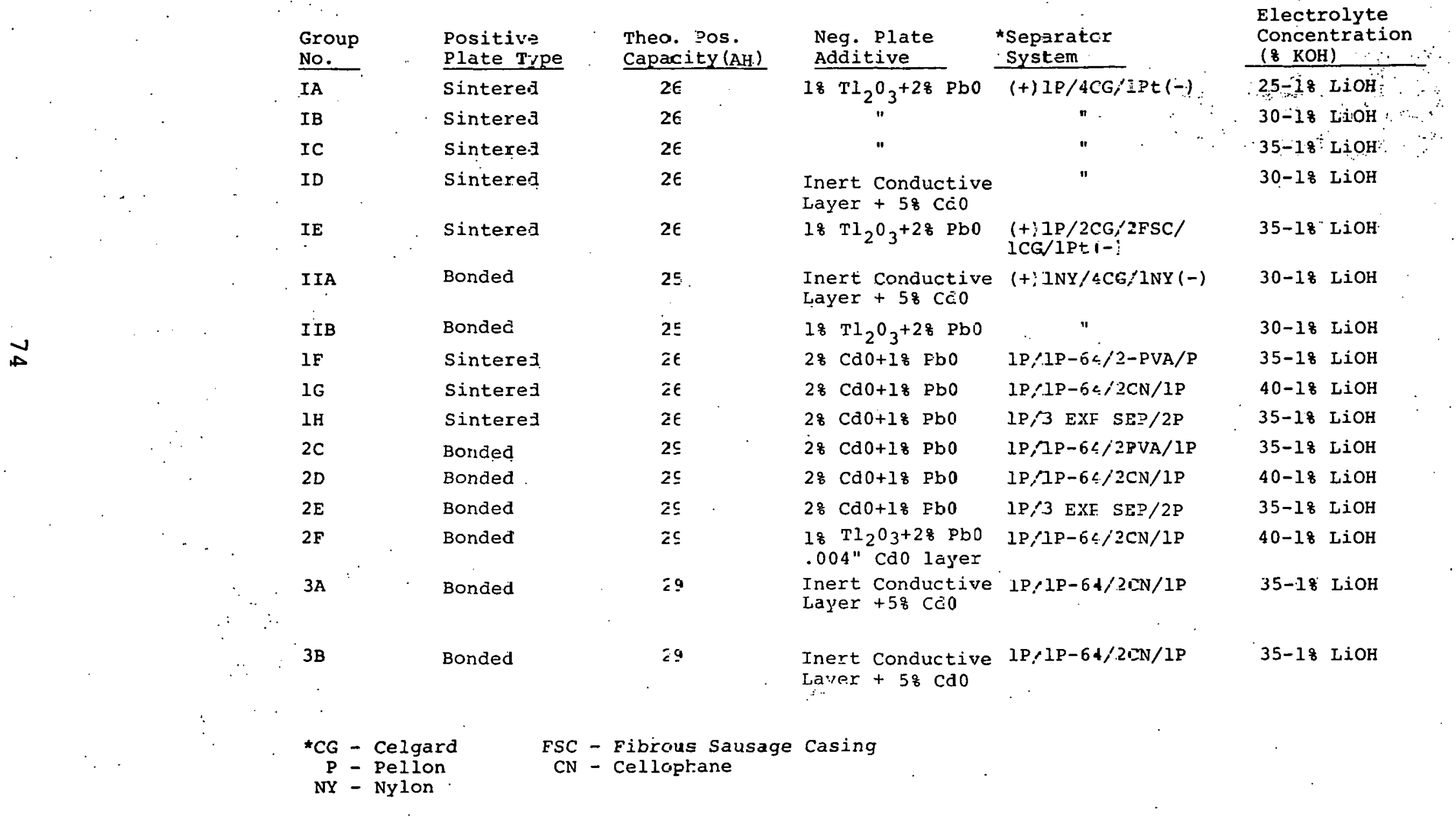




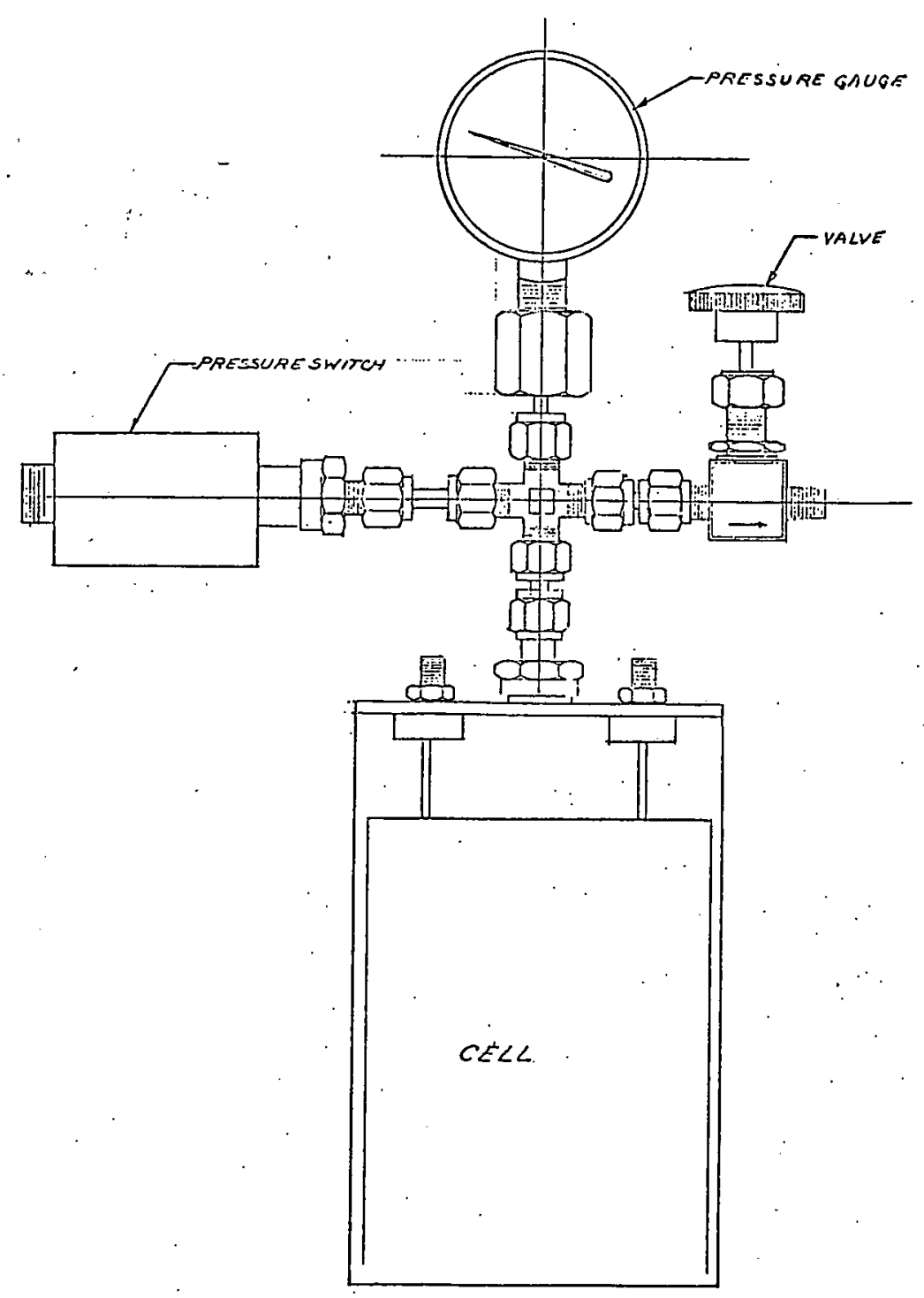

Figure 1. 20 AHR SEALED Ni-Zn CELI 
The procedure is different for cells with celgard as the only separator material. To minimize dendrite growth through the larger pores of the celgard, the cells are never run flooded but are drained and sealed before any formation cycles.

oxygen recombination rates are determined for each cell plotting the pressure increase on charge and the pressure decrease on open circuit. This is done at successively higher rates of charge up to the $\mathrm{C} / 4$ rate. The cells are charged to 20 psi unless the rate of pressure increase is slow enough to warrant charging to a higher pressure.

At least two cells of each design were made, so the 34 cells will be split into two identical (at least in design) sets of cells with two test regimens for gas recombination.

The first eet of cells will be tested for recomhination as described above, with successively higher ratec of charge, up to $\mathrm{C} / 4$. The cell.s will then be charged at $\mathrm{C} / 6$ to $25 \mathrm{psi}$ and gas chromatograph samples will be taken to determine the amount of hydrogen evolved. Oxygen will then be introduced externally into the cells and the pressure drop recorded. This will be done at various states of charge.

The second set of cells will be tested for recombination with a slight excess of electrolyte in the cell. The electrolyte will be removed in increments to determine the effect of electrolyte quantity on performance. As in the first series, chromatographic analyses will be performed on the evolved gases and chemical recombination with oxygen will be observed.

Following the recombination experiments, the cells will be put on an automatic cycling routine consisting of $10 \mathrm{~A}$ discharge for 2 hours (or $1.2 \mathrm{~V}$ ) and 3.67A charge for 6 hours (or 25 usi).

Two of the cell groups have 4 cells of the same design. In these groups, two of the four cells will be cycled at a greater depth of discharge to determine the effect on cycle life.

Gas recombination tests will also be performed in a pressure-tight single electrode housing which has been constructed. Single zinc electrodes will be charged in a "dummy" cell and placed in the test chamber into which 25 to 50 psi oxygen will be introduced. The device is also equipped with terminal posts so single cells can be tested for gas evolution and recombination.

\subsection{Cell Test Results}

\subsubsection{Pressure and Voltage Characteristics on Charge}

Figures 3 thru 9 show the pressure and village characteristics of cells from Groups 2C, IIA, 2D and 2E. The pressure curves on charge exhibit two linear portions, with a slow rate of increase early in the charge and a much more rapid increase later in the charge. The shift to the faster rate of increase 


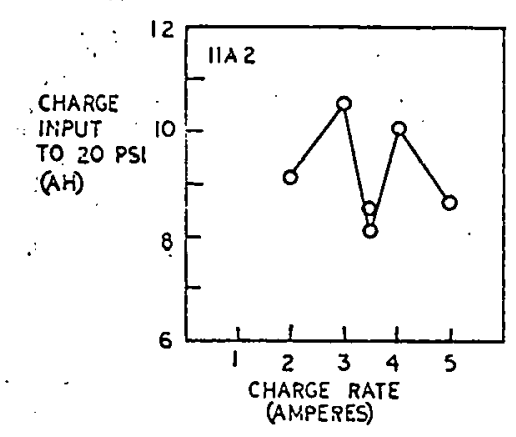

CHARGE ACCEPTED TO 20 PSI VS CHARGE

RATE
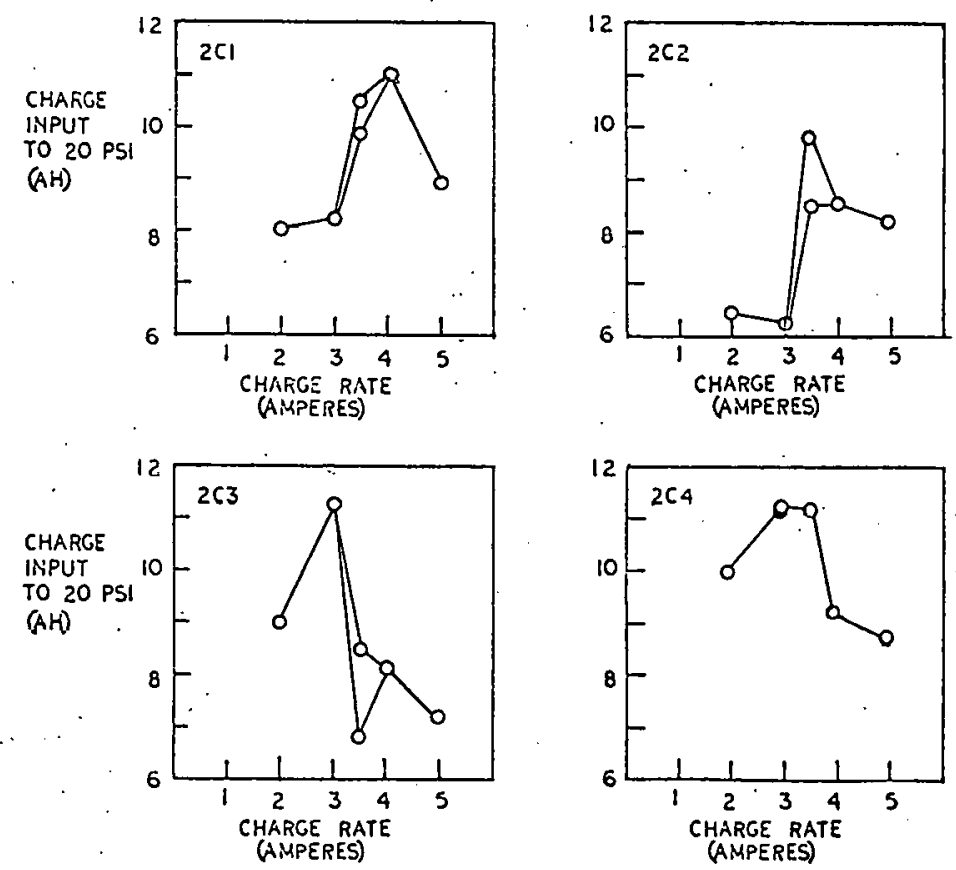

FIGURE 2. GROUP 2C, CELL IIA2 


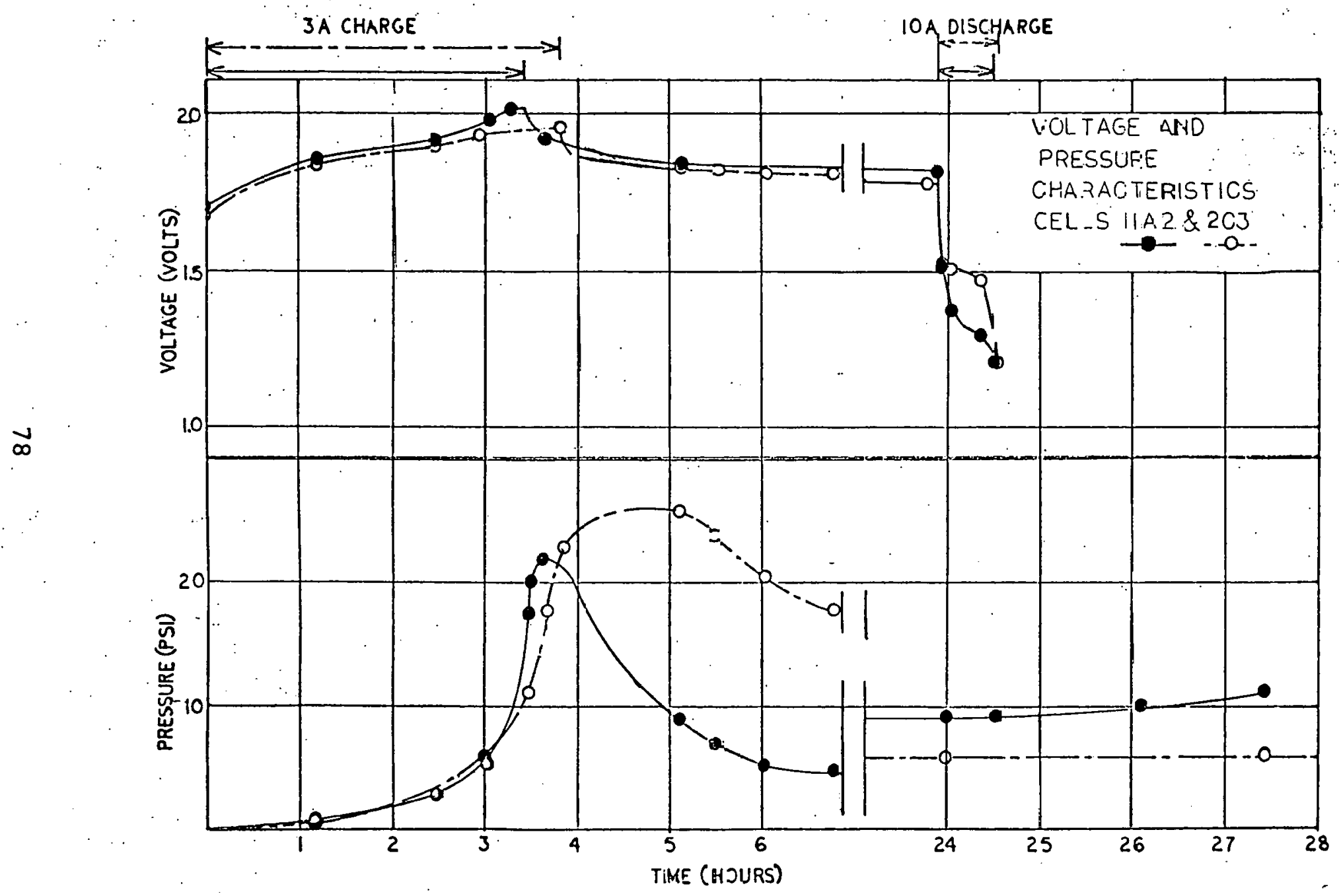

FIGURE 3. CELLS ITA2 \& 2C3, VOLTAGE AND PRESSURE CHARACTERISTICS 

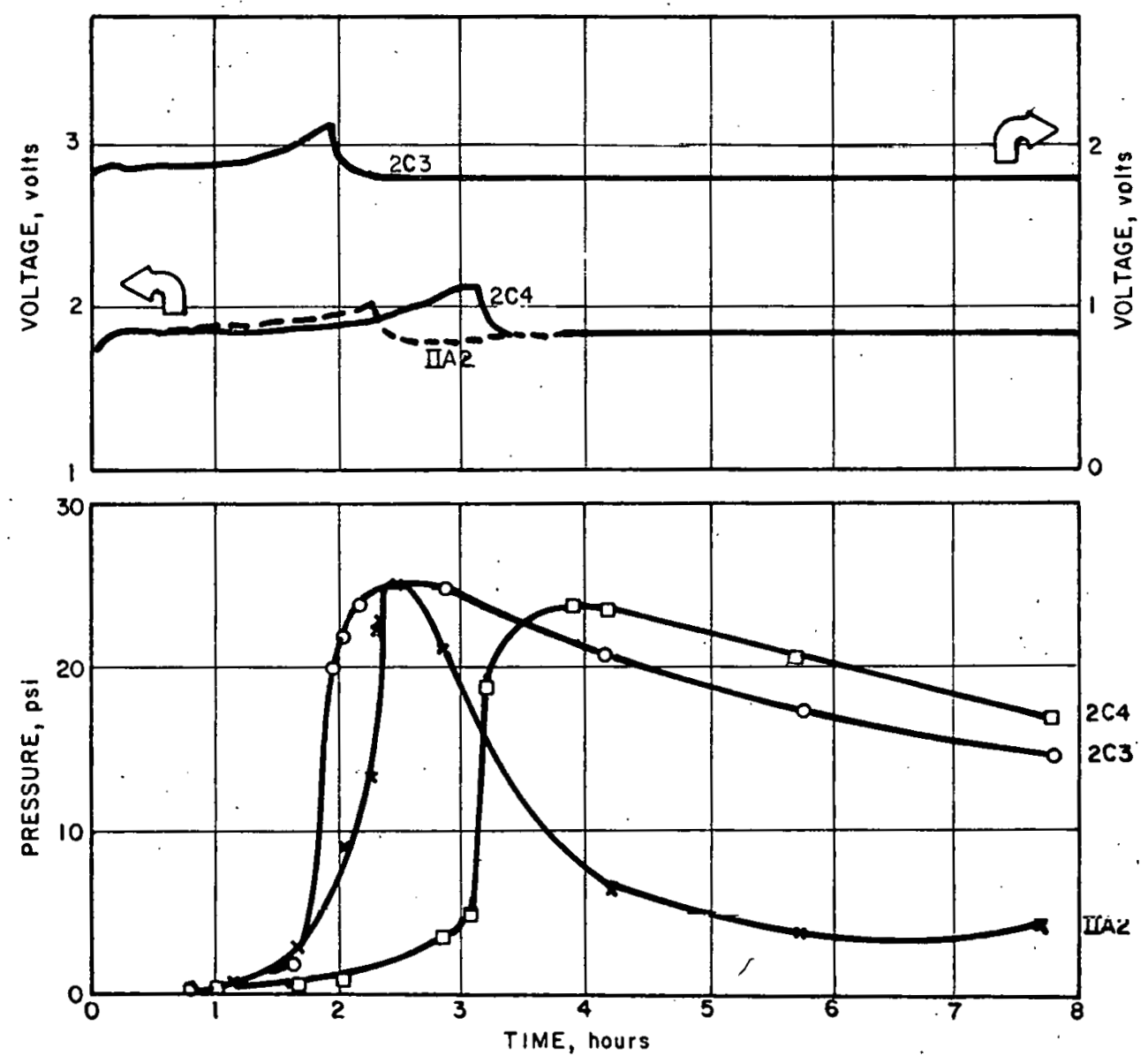

FIGURE 4

CELLS 2C3, 2 C4 \& IIA2 VOLTAGE a PRESSURE CHARACTERISTICS AT 4A CHARGE 
is usually accompanied by an increase in the cell voltage as the nickel electrode accepts less charge and produces more oxygen.

In some cases the pressure continues to rise after the charge has been cut off. The pressure eventually decreases to about 5 psi and begins to rise slowly as hydrogen is generated by self discharge of. the zinc electrode.

of the cells tested so far, Group $2 \mathrm{C}$ exhibits the slowest rate of recombination after charge. The pressure generally rises about 5 psi after the charge has been cut off and returns to the cut off pressure after about three hours. Figures 3 and 4 show pressure and voltage data for cells from Group 2C.

Figure 3 compares the voltage arid pressure data of cells IIA 2 and $2 \mathrm{C} 3$ on charge, open circuit, and discharge. While IIA3 has a higher rate of pressure increase in charge, the rate of recombination on open circuit is greater than for cell $2 \mathrm{C} 3$. The pressure increases about 3 psi heyond the cutoff point, but returns to the cut off pressure after about 30 minutes.

The recombination characteristics of Group $2 \mathrm{C}$ and cell IIA2 are generally slow. The gas generation severely limits the amount of charge that can be given to the cells. The charge input to 20 psi for the cells at different charge rates is shown in Figure 2.

Considering the open pore structure in the Celgard separator, the poor performance of cell IIA2 is surprising. Cell IIAl has been built and initial test results show performance superior to cell IIA2. On its second cycle, IIAl accepted 15.3 Ah before reaching the 20 psi cut off. This is superior to both IIA 2 and Group 2C.

Iable II shows the pressure controlled charge data for Group 2D. While the performance is generally better than that of Group 2C or IIA2, the 3A charge curves of 2D2, 2D3, and 2D 4 indicate that shorts may have been developing in the cells. The voltage and pressure curves for the $3 \mathrm{~A}$ and the $2.2 \mathrm{~A}$ charge are shown in Figures 5 thru 8.

TABLE II

GROUP 2D PRESSURE CONTROLLED CHARGE CHARACTERISTICS

\begin{tabular}{|c|c|c|c|c|c|c|c|c|}
\hline $\begin{array}{l}\text { Charge } \\
\text { Rate }\end{array}$ & $\begin{array}{l}\text { Chars } \\
20 \mathrm{p}\end{array}$ & $\begin{array}{l}\text { Input } \\
\text { (Ah) }\end{array}$ & to & & Discl & arge & pacit & $(\mathrm{Ah})$. \\
\hline (Amperes) & $2 \mathrm{Dl}$ & 2D2 & 2D3 & $2 \mathrm{D4}$ & $2 \mathrm{Dl}$ & $2 \mathrm{D} 2$ & $2 \mathrm{D3}$ & $2 \mathrm{D} 4$ \\
\hline $\begin{array}{l}2 \\
2.2 \\
3\end{array}$ & $\begin{array}{l}16.6 \\
13.4 \\
11.9\end{array}$ & $\begin{array}{l}16.6 \\
11.4 \\
9.25\end{array}$ & $\begin{array}{l}17.4 \\
11.7 \\
8.55\end{array}$ & $\begin{array}{l}17.8 \\
13.4 \\
9.55\end{array}$ & $\begin{array}{r}16.7 \\
6.2 \\
10.5\end{array}$ & $\begin{array}{r}16.4 \\
7.5 \\
8.5\end{array}$ & $\begin{array}{r}17.2 \\
6.5 \\
8.5\end{array}$ & $\begin{array}{r}18.0 \\
7.5 \\
8.5\end{array}$ \\
\hline
\end{tabular}



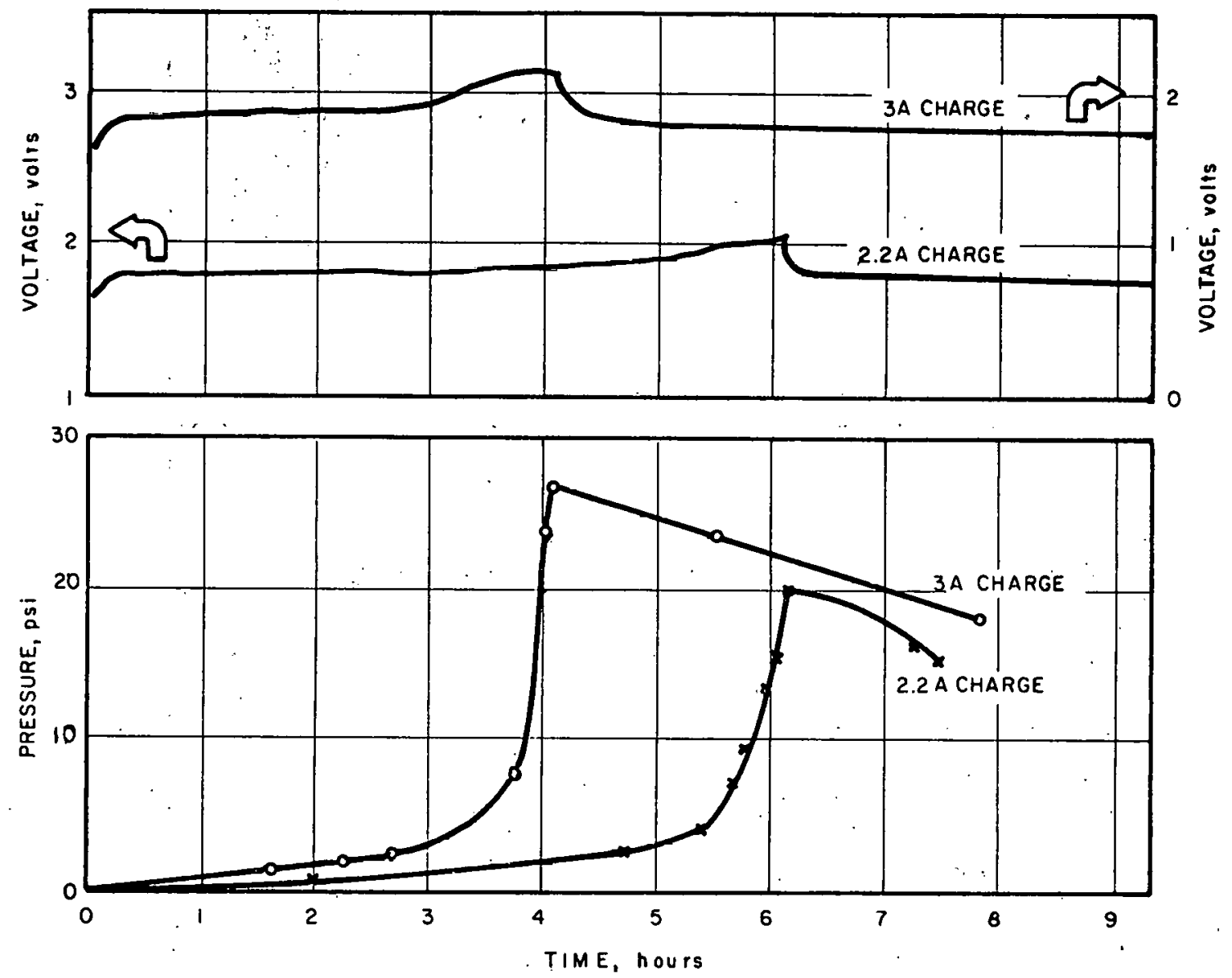

FIGURE 5

CELL 2DI VOLTAGE \& PRESSURE CHARACTERISTICS 

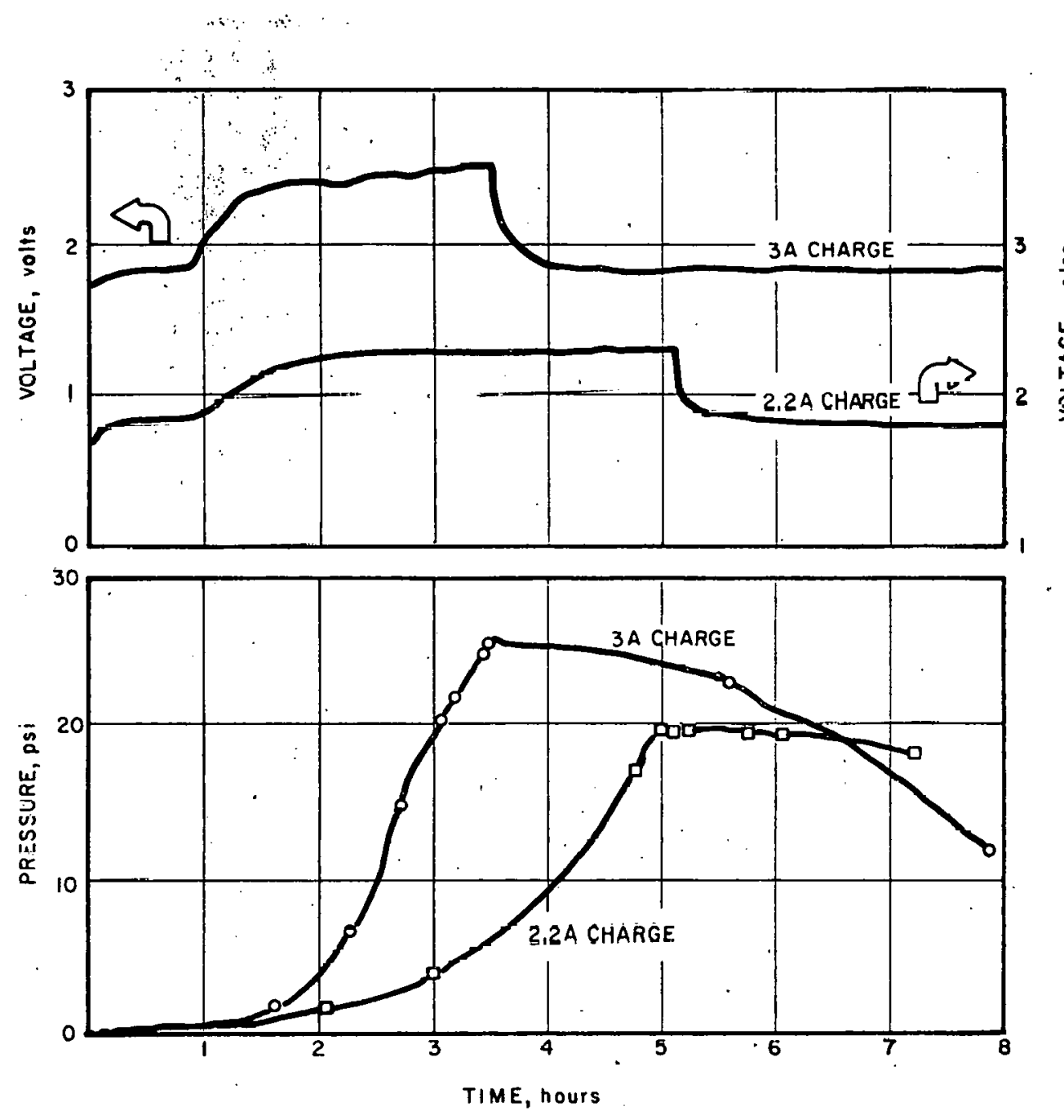

FIGURE 6

CELL 202 VOLTAGE \& PRESSURE CHARACTERISTICS 


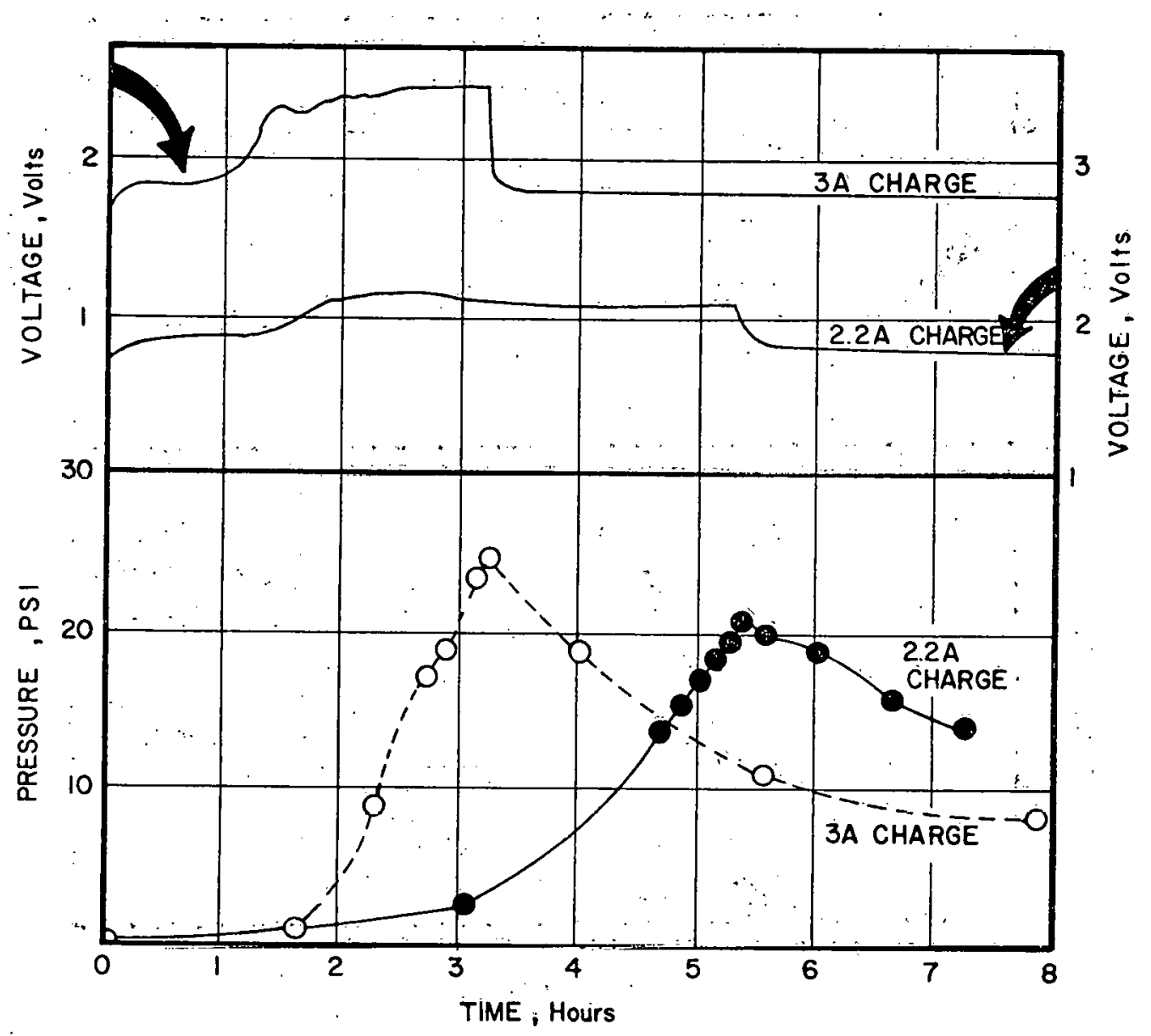

FIGURE 7. CELL 2D3, VOLTAGE \& PRESSURE CHARACTERISTICS 


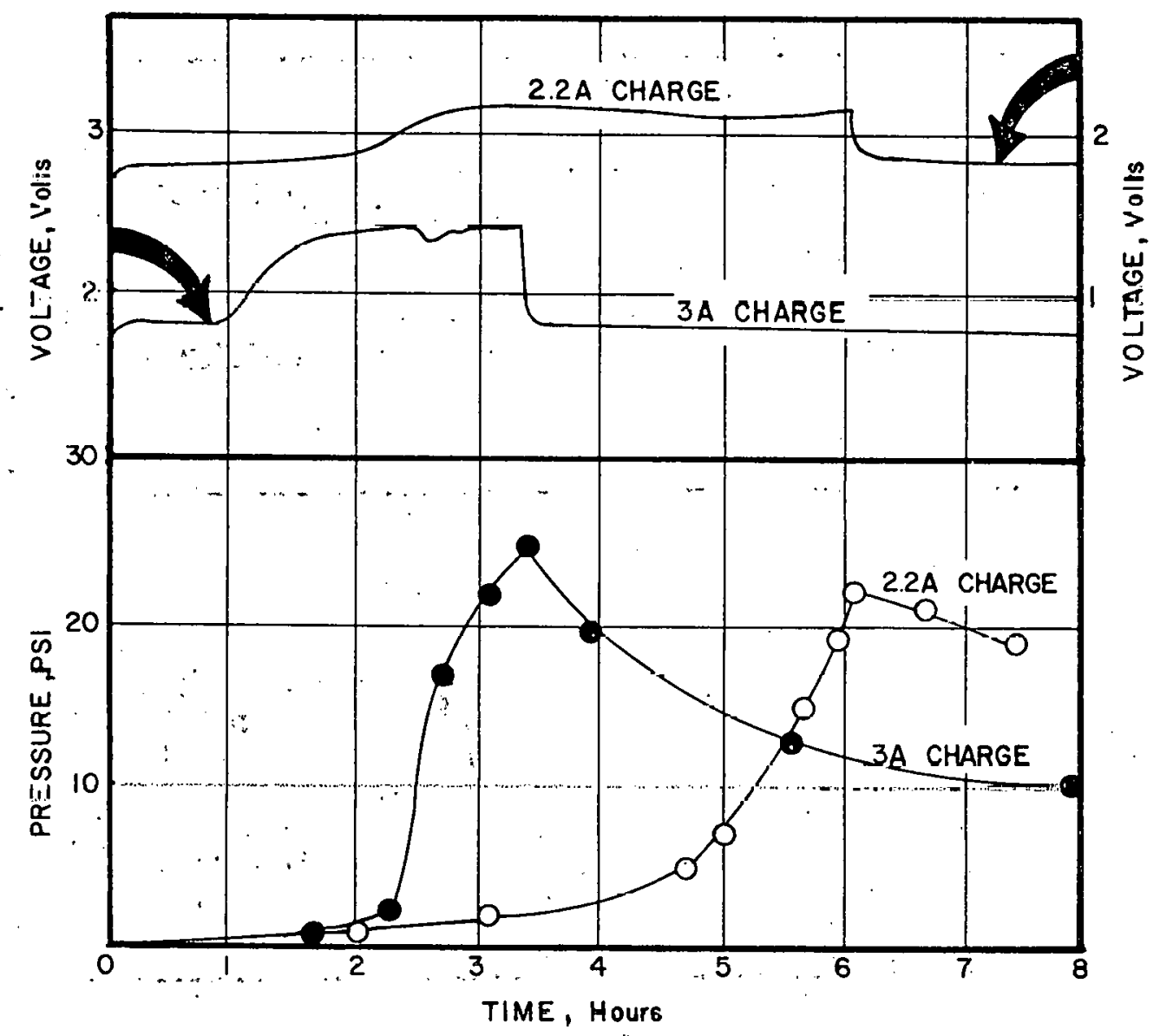

FIGURE 8. CELL 2D4, VOLTAGE \& PRESSURE CHARACTERISTICS. 
FIGURE 9

CELL 2E1 3A CHARGE
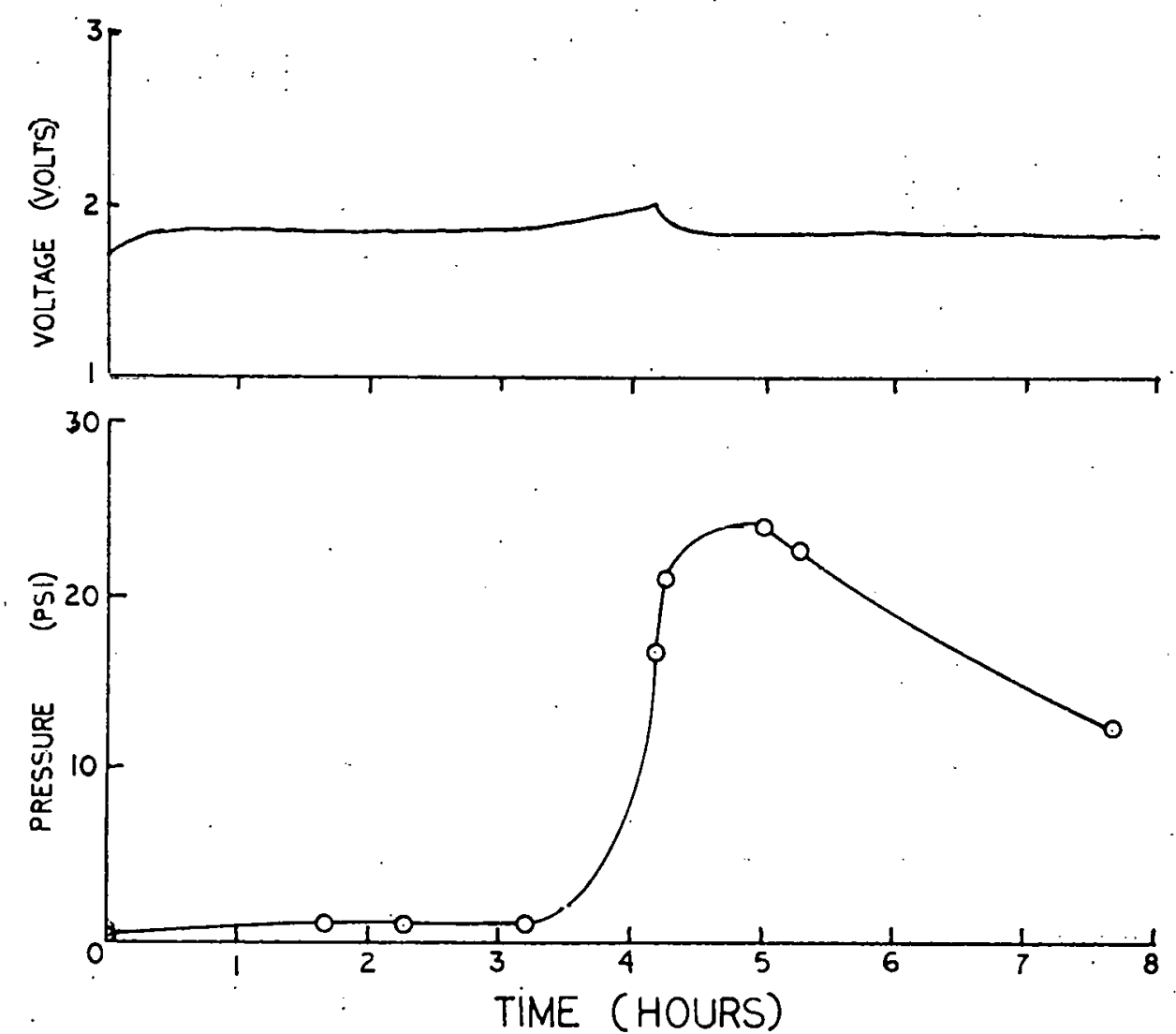
TABLE, III

OPEN CIRCUIT GAS GLNERATION RATES

\begin{tabular}{|c|c|c|c|c|}
\hline LE'LL & $\begin{array}{l}\triangle \mathrm{P} \text { OVER } \\
16 \text { HOURS } \\
\text { (psi) }\end{array}$ & $\begin{array}{l}\text { RATE } \\
\text { PSI' } \\
\text { HOUR } \\
\end{array}$ & $\begin{array}{ll}\triangle P & \text { OVER } \\
66 & \text { HOURS } \\
\end{array}$ & $\begin{array}{l}\text { KATF. } \\
\text { PSI/HOUR }\end{array}$ \\
\hline $2 \mathrm{Cl}$ & 2 & .125 & 8 & .121 \\
\hline $2 \mathrm{C} 2$ & 2 & .125 & 5.5 & .083 \\
\hline $2 \mathrm{C} 3$ & 5 & .313 & 15 & .227 \\
\hline $2 \mathrm{C} 4$ & 3 & .188 & 10 & .152 \\
\hline IIAI & 8 & .500 & 31 & .470 \\
\hline IIA2 & 11 & .688 & 27.5 & .417 \\
\hline KKB I & 1 & .063 & 19 & .288 \\
\hline IIB2 & 1 & .063 & 9.5 & .144 \\
\hline 241 & 3 & .188 & 11 & .167 \\
\hline 2D2 & 7 & .438 & 19 & .288 \\
\hline 2D 3 & 2 & .125 & 7 & .106 \\
\hline 2D4 & 5.5 & .344 & 9 & .136 \\
\hline $2 E l$ & $?$ & .135 & 11 & .167 \\
\hline $2 E 2$ & 5 & .313 & 23 & .348 \\
\hline
\end{tabular}




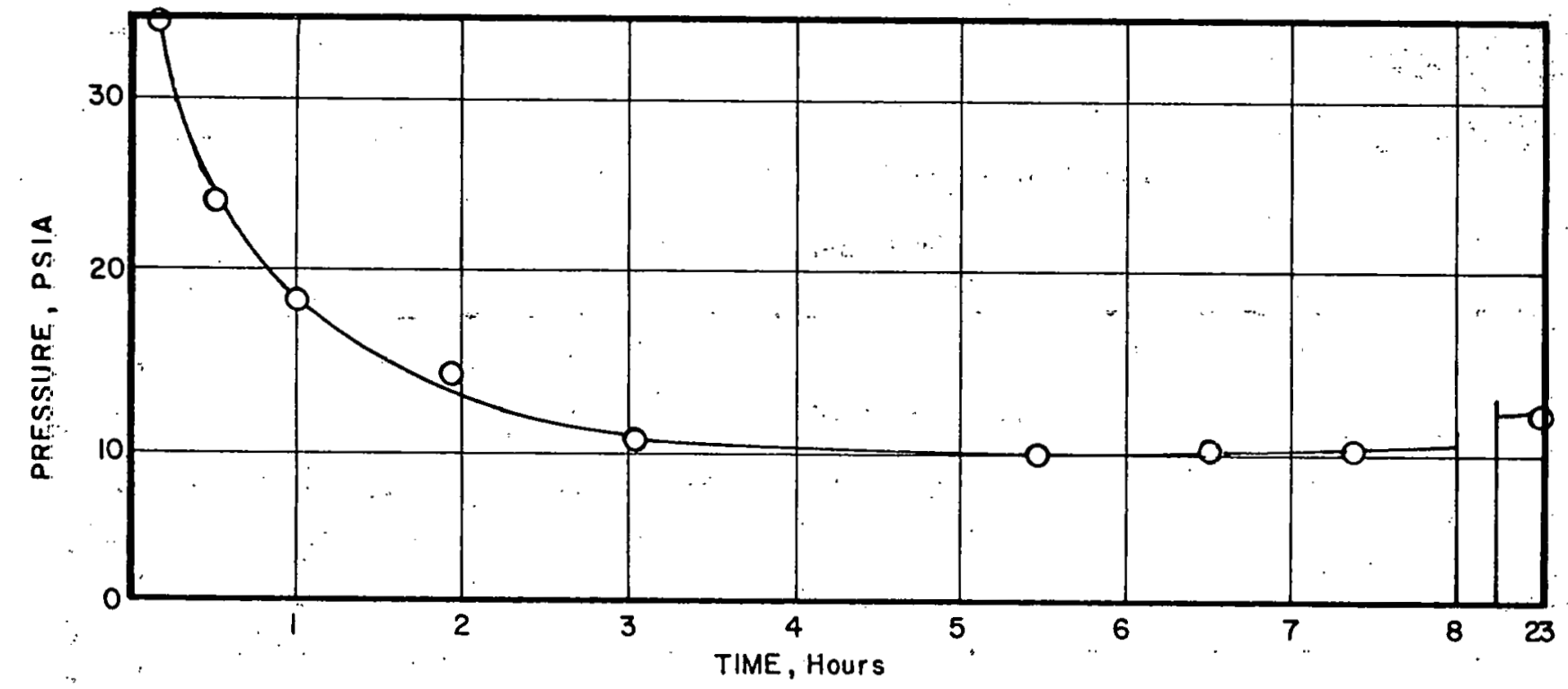

FIGURE 10. CELL 2C2,- RECOMEINATION TEST 


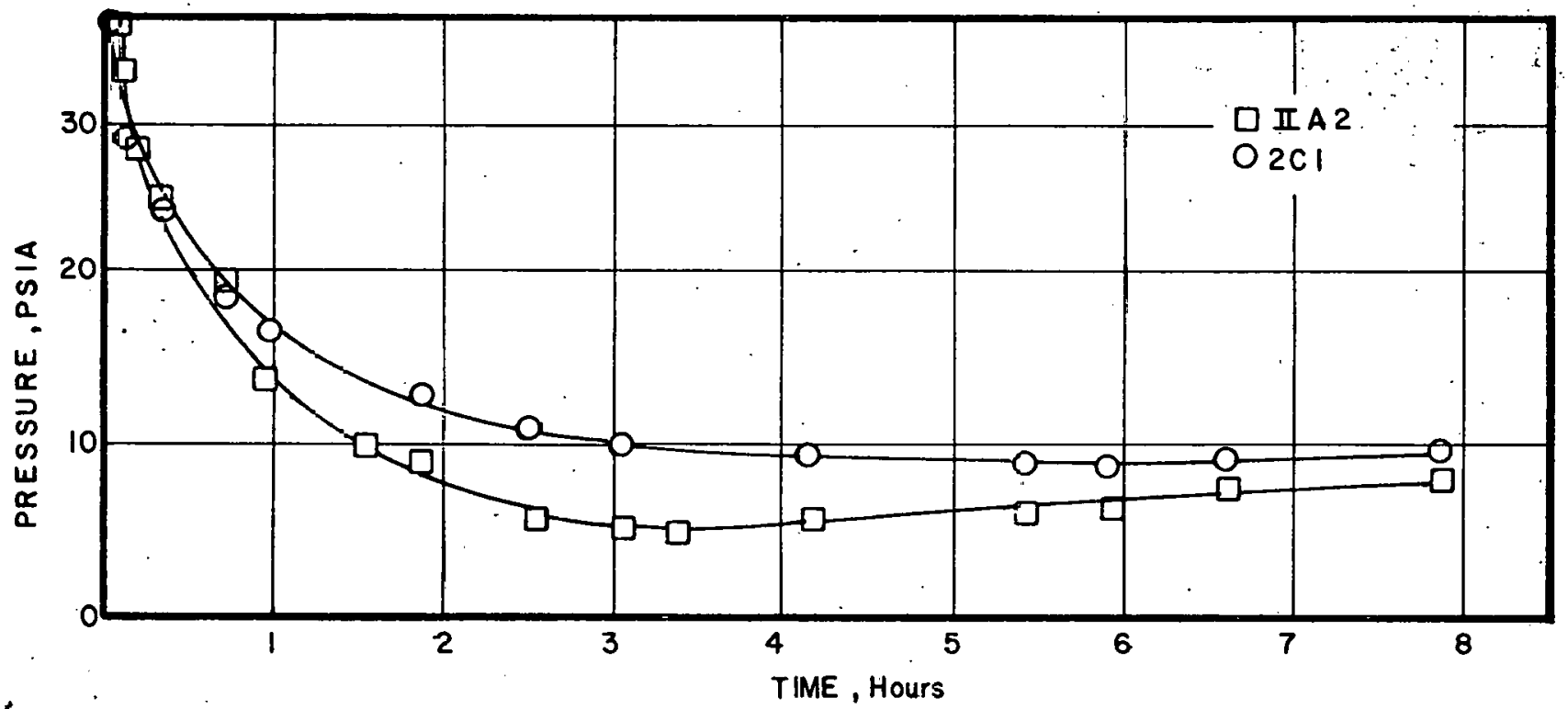

FIGURE 11. CELLS $2 \mathrm{Cl}$ and IIA2, RECOMBIMATION TESTS 


\section{FIGURE 12}

CELLS 2D3 and 2D4., RECOMBINATION TESTS

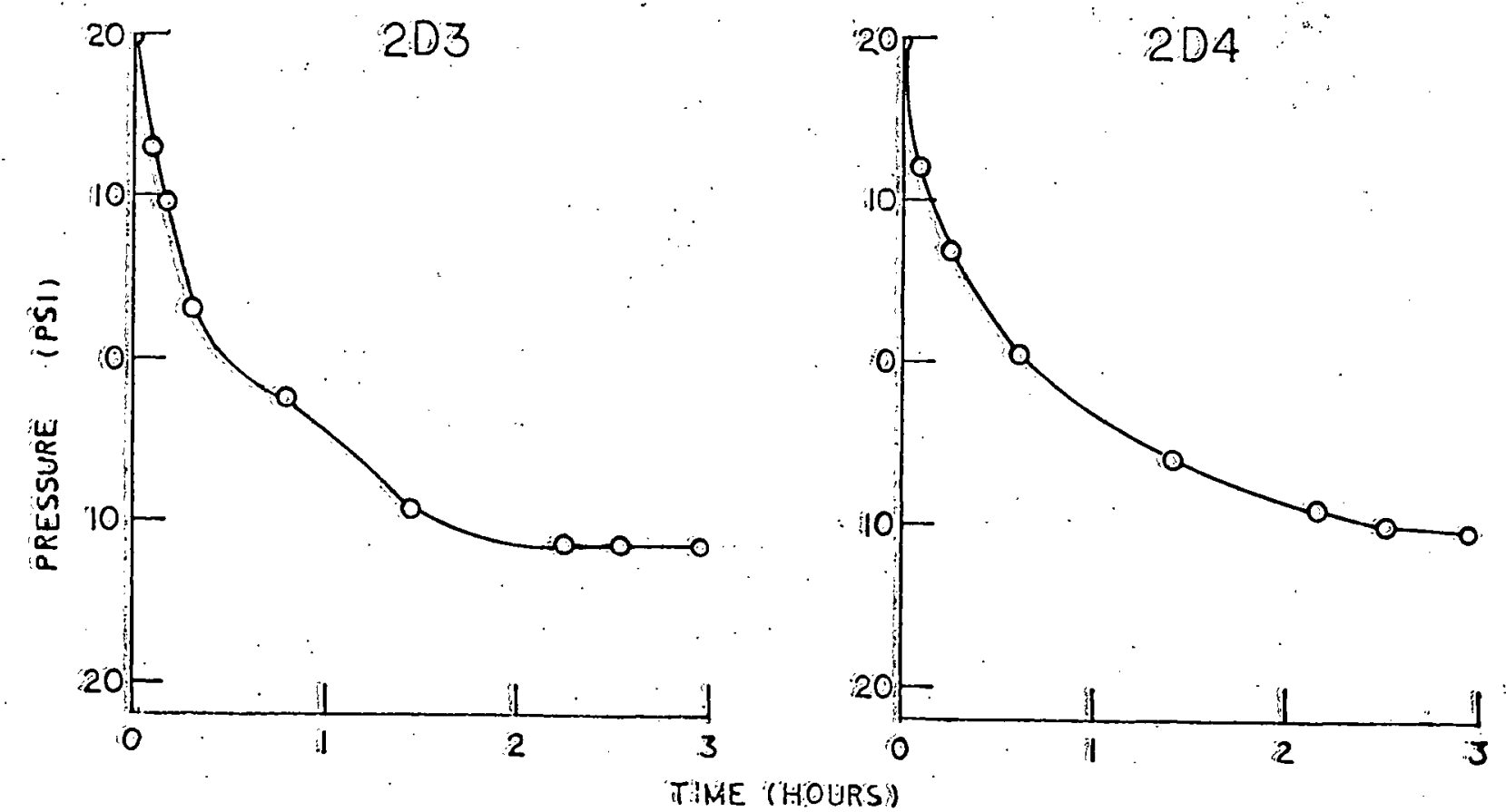


The pressure rise on charge is usually slower for Group 2D. During the 3 amp charge, the cells were charged to 25 psi resulting in as much as 40 minutes charge time after the 20 psi point had been reached. Unlike Group $2 \mathrm{C}$ or IIA, the cells in Group 2D show an immediate pressure drop when the charge current is cut off.

In addition to formation cycles, Group $2 \mathrm{E}$ ( 2 cells) and Group 2B ( 2 cells) have each been given a $3 \mathrm{~A}$ charge in the sealed condition. $2 \mathrm{El}$ and $2 \mathrm{E} 2$ accepted 12.75 and 14.0 Ah to the 20 psi cut off. $2 \mathrm{Bl}$ and 2B2 accepted 16.45 and $15.2 \mathrm{Ah}$ respectively. Figure 9 shows voltage and pressure characteristics of cell $2 \mathrm{El}$.

\subsubsection{Gas Generation on Open Circuit}

A major problem with the sealed cells is the hydrogen gas generated on open circuit due to zinc corrosion. Chromatograph analysis of gases from cells left on open circuit indicates that the gas is hyrrngen with traces of nitrogon and oxygen, presumably from the air initially sealed in the cell.

The pressure build-up from hydrogen generation makes regular venting of the cells necessary to prevent bursting. Table III shows the gas generation rates over 16 and 66 hour periods.

\subsubsection{Chemical Recombination Tests}

Cells 2Cl, 2C2, 2IIA2, 2D 3 and 2D4 have all been tested for direct chemical recombination by introducing 20 psi oxygen into the charged cells. Despite its poor charging characteristics, cell IIA2 performed better than the cells from Groups 2C and 2D. The pressure in IIA2 leveled off at 11.5 pei vacuum after six hours and 202 reached a low of 13.5 psi vacuum after 6 hours.

Group 2D performed better than Group 2C, leveling off below 10 psi vacuum after 3 hours. The data for this test is shown in Figures 10 thru 12 . 


\subsection{CONCLUSIONS}

Rates of oxygen recombination and hydrogen evolution have been determined for various $20 \mathrm{Ah}$ sealed cell designs.

Removal of free electrolyte to enhance oxygen recombination also results in a loss of capacity.

During the next 12 months, work will continue on methods for improving $\mathrm{O}_{2}$ recombination without sacrificing cell capacity. This investigation will center on the use of inexpensive recombination electrodes employing various oxygen electrocatalysts. Both 20 and $250 \mathrm{Ah}$ size cells will be tested. 
THIS PAGE

\section{WAS INTENTIONALLY LEFT BLANK}




\section{SECTION VI \\ SYSTEM ENGINEERING - TASK V}




\subsection{INTRODUCTION}

The goal of this phase of the ANL Program is the development of an EV type battery incorporating the advances made in component technology, manufacturing methods and design concepts.

Our attention during this reporting period was divided into design, fabrication and testing of $20 \mathrm{Ah}$ and $250 \mathrm{Ah}$ vented nickel-zinc cells, charge control methods, and cell modeling and data reduction using a digital computer.

The following sections present a technical discussion on our investigative efforts. 
2.0 TECHNICAL “DISCUSSION.

CELL DESIGN, FABRICATION AND TESTING

$2.120 \mathrm{AH}$ Cells

Electrochemical designs for two types of cells, a large EV type cell and a small 20. Ah cell, were prepared. The smaller size cells are test vehicles to evaluate the design, components and electrolyte composition. Both types were positive limited and contained rectangular electrodes individually bagged in the separator material. The salient features of the design are given in Table $I$.

A number of cells of both types were fabricated. Furthermore, alterations were made in the baseline design with respect to the number and type of electrodes, the separator system and ampere-hour capacity of the electrode sandwich.

\subsection{Cell Design}

The construction of cells consisted essentially of nickel positive electrodes, zinc negative electrodes and separators. The electrodes were all of the bonded and pressed type as opposed to the conventional sintered nickel plaque electrodes. The components were assembled in a transparent polysulfone. case, terminals soldered and cover ultrasonically sealed. The cells were filled with electrolyte, allowed to stand for 72 hours and tested.

Initially, about 40 cells were built with various mix formulae for the negative electrode. The cells were tested on an automatic cycler.

Each cell was tested until the discharge capacity dropped to below $12 \mathrm{Ah}$ with an end voltage of $1.25 \mathrm{~V}$. The cell voltages were monitored continually by means of recorders. The electrolyte level was maintained by topping up with 5\% $\mathrm{KOH}$ solution as required to compensate for electrolyte losses. At the completion of tests, sample cells were dissected to check for dendrite growth, shurts, positive ewelling, negative shape change, separator degradation, etc.

In the first group of cells, the electrode size, number of electrodes per cell and separator configuration were kept the same.

The negative mix was varied by the addition of cdo, Hgo, and various proprietary additives. The combinations are listed in Table IA.

An examination of Table IA shows that cycle life varies from 46 to 132. The mix containing Hgo gave only 46 cycles and this has to be investigated further. Even though mix No. 1 which contained no additive gave about 80 cycles, the cell was tested immediately after it was built and it is to be experted that the same number of cycles cannot be obtained 


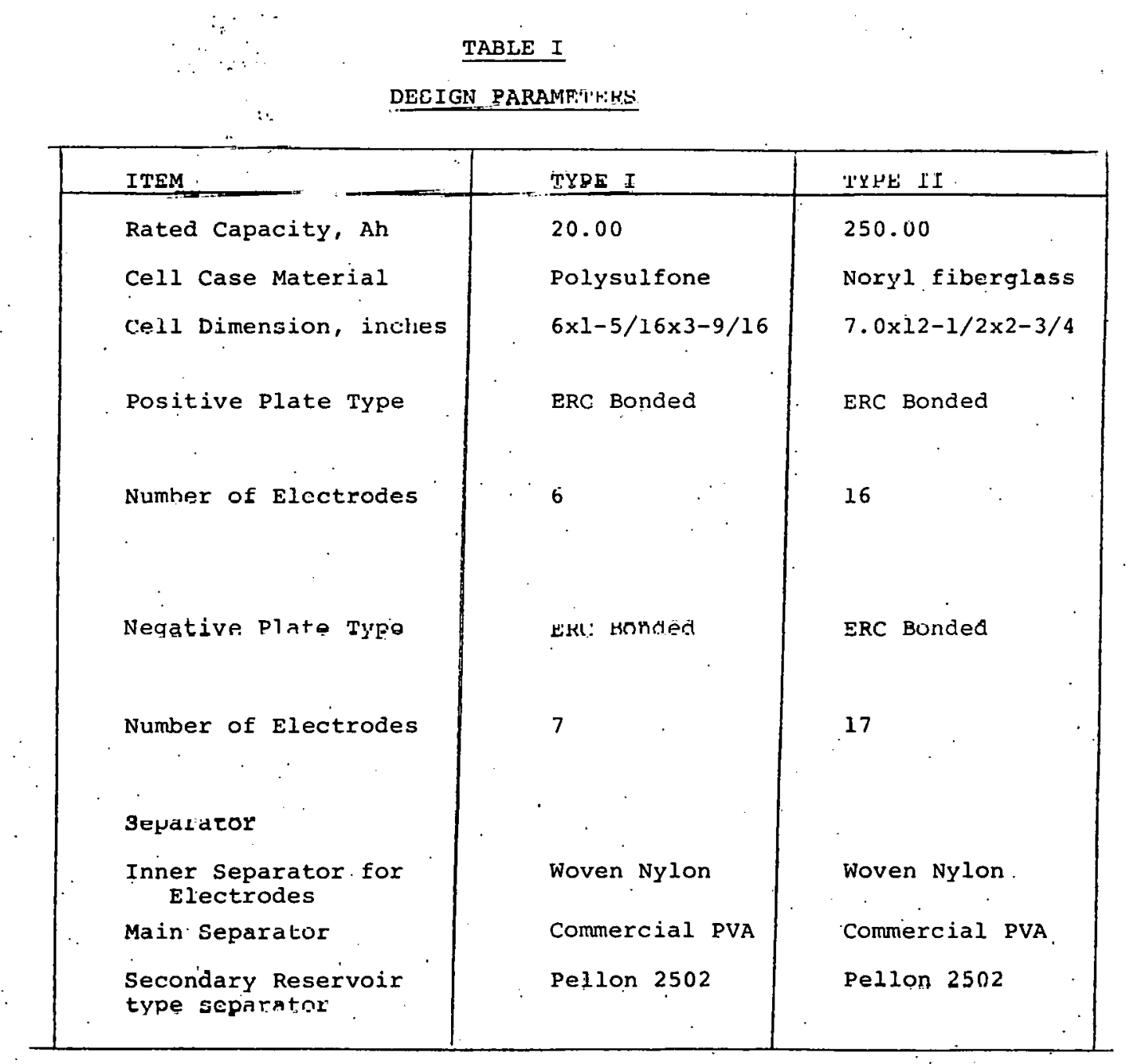


TABLE I A CYCLE LIFE OF 20 AH CELLS

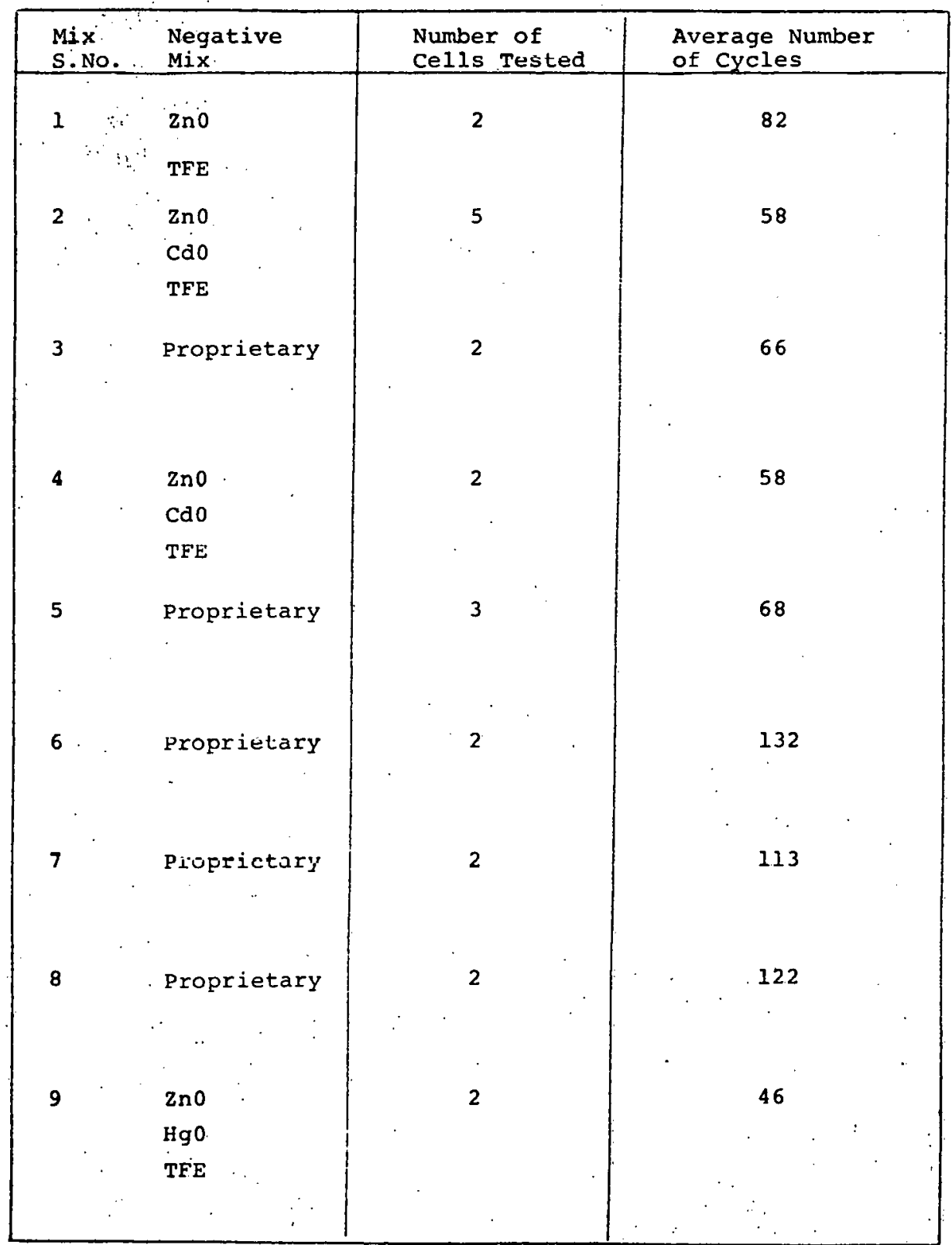


after wet stand since self discharge of zinc would be critical. Cells fabricated using ERC proprietary additives displayed cycle life from 68 to 132 .

A group of six (6) 20 Ah vented $\mathrm{Ni}-\mathrm{Zn}$ cells (Group 1) was fabricated to test the effectiveness of the rolling procedure used in the manufacture of positive electrodes. Of the six cells fabricated, three contained positive electrodes fabricated from ERC precipitated $\mathrm{Ni}(\mathrm{OH})_{2}$ batch \#54-102 and the other three contained those from batch \#81-52A. All the six cells were assembled in an identical manner and were filled with the same quantity of $35 \% \mathrm{KOH}$ and $1 \% \mathrm{LiOH}$ electrolyte. The variable being studied in the rolling procedure is the degree of mulling. Degree of mulling may be classified into:

MAXIMUM: Mulling to the point that a omall anount of cracking will occur on rolling.

NORMAI: Mulling to the point that the sheet has one less pass than required to make a satisfactory sheet.

MINIMUM: Mulling to the point that it has just enough adhesion to form a sheet.

The test procedure after cell assembly consisted of alternately charging and discharging the cells in an automatic cycler. The depth and rate of discharge amounted to $83 \%$ and C/2, respectively for each cycle. The experimental results are summarized in Table II.

Cells made from ERC $\mathrm{Ni}(\mathrm{OH})$, batch \#54-102 had poorer nickel utilization and poor cycle life when the mulling was minimum but improved considerably when mulled to normal or maximum level. There was no noticeable iffference in the eleclruchemical performance of the cells made from ERC batch \#8l-52A. Figures 1 and 2 sluw yraphical representation of capacity decline with cycling for the cells.

It may be concluded from the above data that although mulling is a critical operation, minute changes in the degree of mulling do not affect the electrochemical performance, if the nickel hydroxide has the desired characteristics.

A secund group of 4 celìs was fabricated to test the effectiveness of a proprietary additive (B-l) as a $\mathrm{Hg}$ substitute in the zinc electrode. The cells, with a rated capacity of $20 \mathrm{Ah}$, were again lested for cycle life in an automatic cycler. The amp-hour capacity of the cells at each discharge cycle and the original number of cycles at which the capacity declined below $60 \%$ of the theoretical positive capacity were determined. Table III summarizes thc experimental results. The results show that this proprietary additive is effective as an Hg substitute to a certain. extent. Furthermore, the amount of additive in the negative electrode mixture had no effect on the cycle life. The 
TABLE II

RESULTS OF MULLING EXPERIMENTS

\begin{tabular}{|llllllll|}
\hline GROUP & I & \multicolumn{4}{c}{ II } \\
\hline Ni Type & ERC & $54-102$ & & \multicolumn{2}{c|}{ ERC $81-52$ A } \\
\hline Cell No. & 25 & 26 & 27 & 28 & 29 & 30 \\
\hline No. of Cycles & 20 & 55 & 56 & 68 & 82 & 70 \\
\hline $\begin{array}{l}\text { Avg. Discharge volts } \\
\begin{array}{l}\text { Max. Discharge } \\
\text { Capacity.(AH) }\end{array}\end{array}$ & 1.34 & 1.43 & 1.37 & 1.56 & 1.551 .55 \\
\hline
\end{tabular}




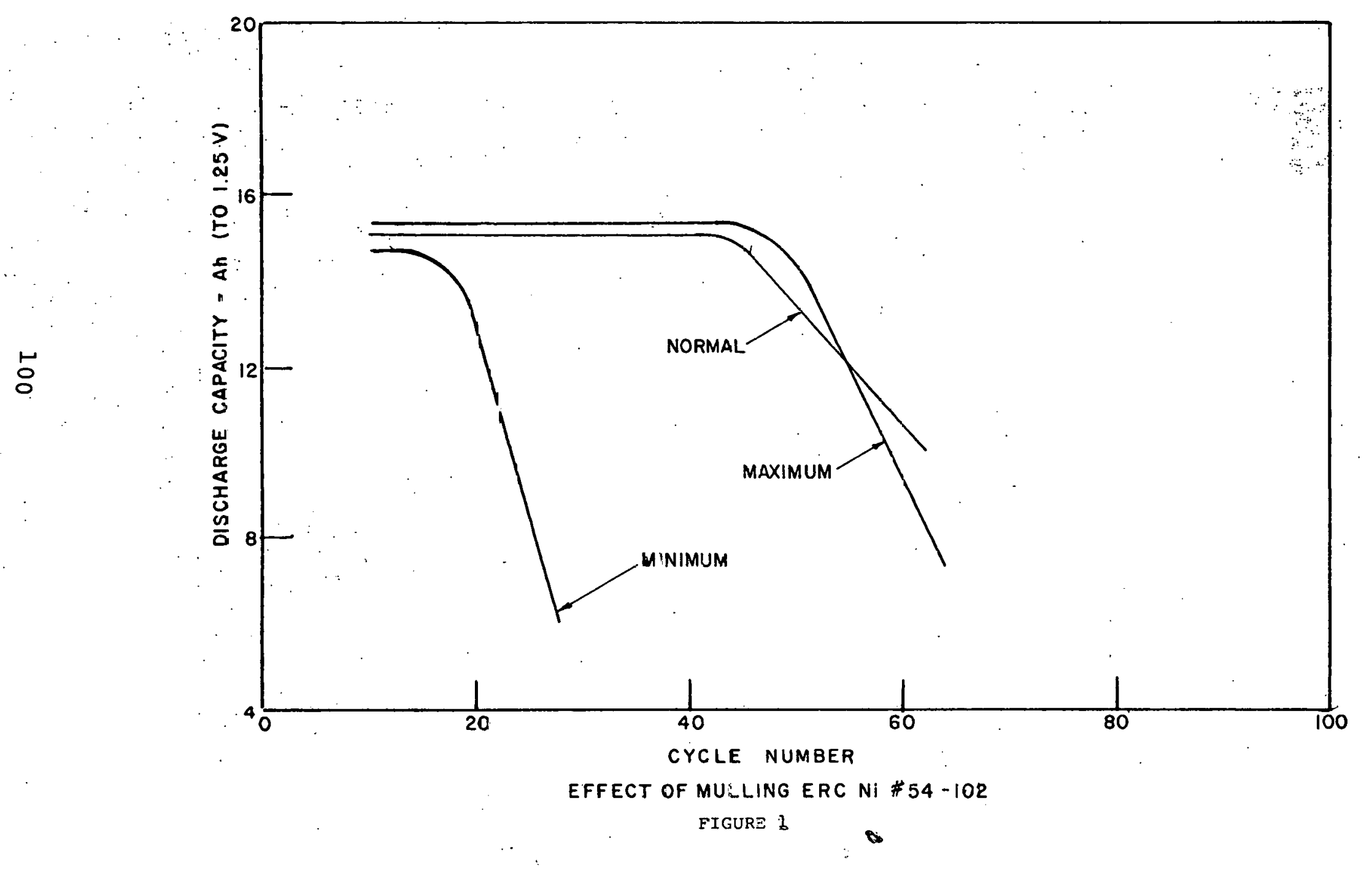




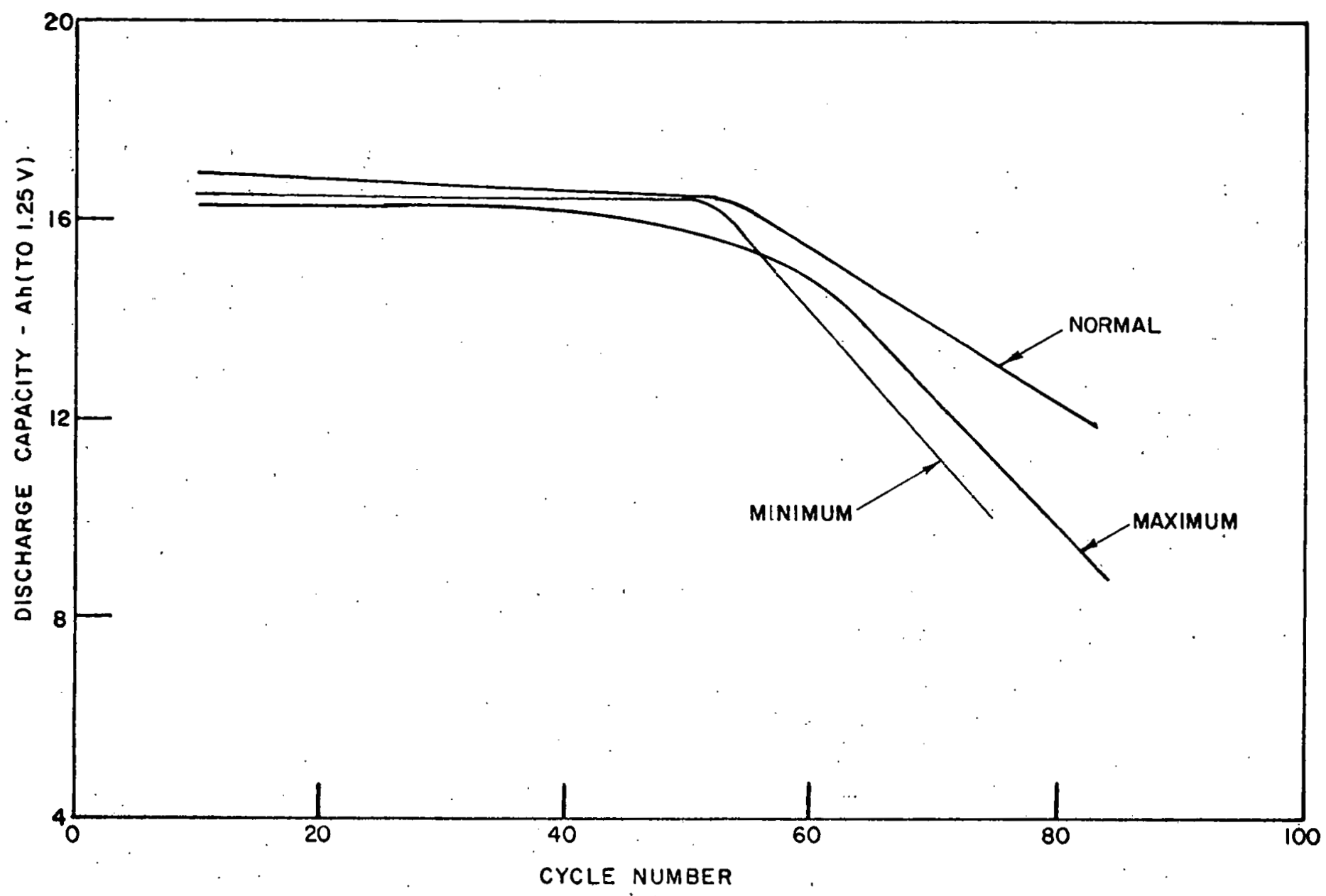

EFFECT OF MULLING ERC Ni \#81-52A

FIGURE 2 
TABLE III

EVALUATION OF B-I ADDITION TO THE NEGATIVE PLȦTES

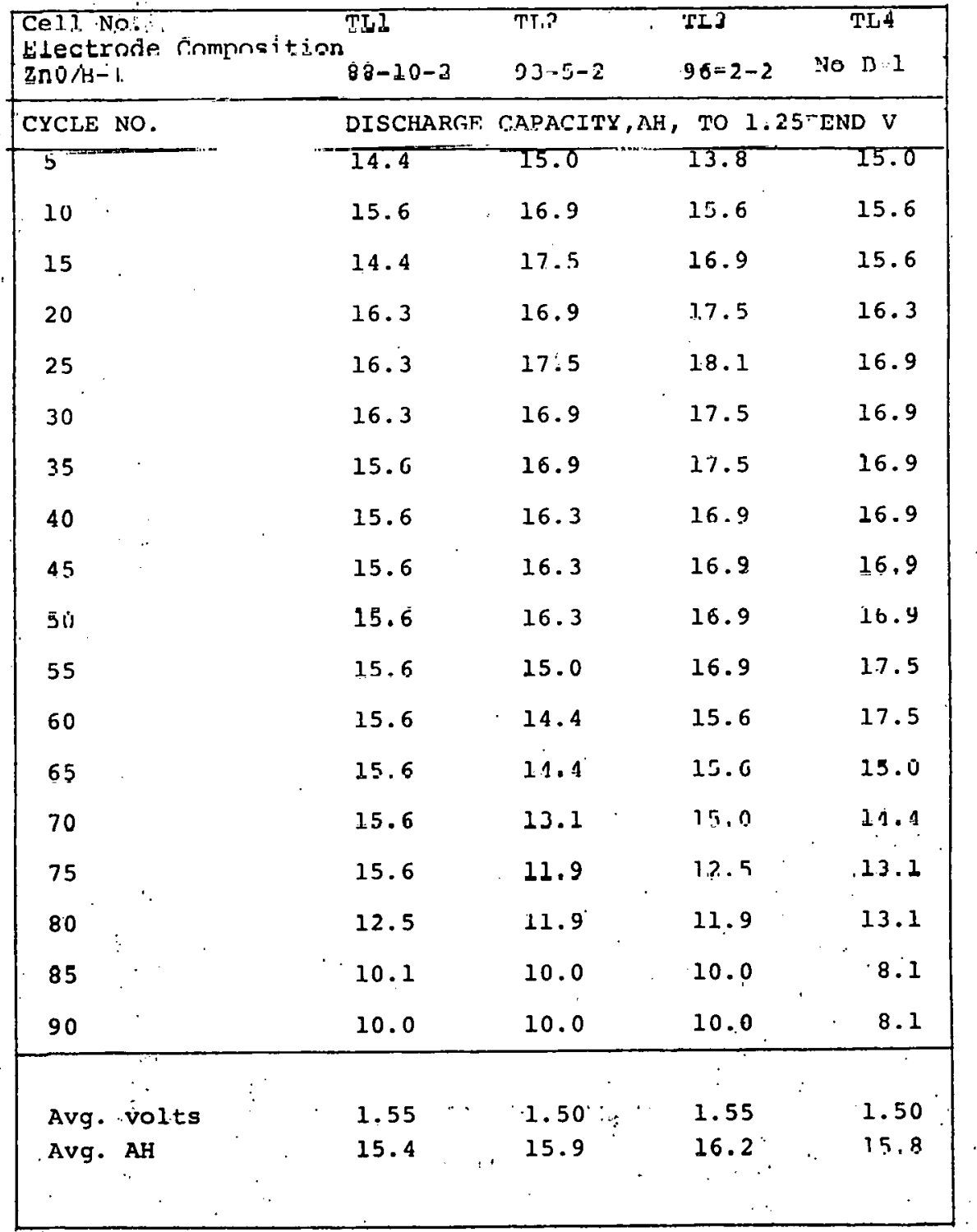


experiments are being continued to evaluate the effect of $\mathrm{B}-1$ in combination with cdo.

A group of fifteen (15) 20 Ah cells was fabricated and their cycle life was determined. Table IV details the performance of these cells. Capacity decline for representative samples of this group of four cells is illustrated in Figure 3 .

\section{$2.3 \quad 250 \mathrm{AH}$ Cells}

A total of twenty-two (22) EV type cells were fabricated. After assembly the cells were vacuum filled with an electrolyte composition consisting of $35 \% \mathrm{KOH}$ and $1 \% \mathrm{LiOH}$. This was followed by a formation charge at $\mathrm{C} / 12$.

The cells were tested in an automatic cycler in a cycling regime consisting of Charge: Constant current at $40 \mathrm{Amp}$ for 5 hours 45 minutes and Discharge: Constant current at 85 Amp for 2 hours, 15 minutes.

The cell skin temperature was allowed to rise during cycling. There are no pauses in the cycling routine and each cell goes through a total of 3 cycles per day. The duration of overcharge amounts to $17 \%$. The corresponding depth of discharge is $75 \%$.

During charge and discharge the variation of cell voltage with time was recorded on a Rustrak recorder. The data reduction consisted of first tabulating the cell voltage versus time, which formed the input to the computer along with discharge current, end of charge voltage and current and duration of charge. The output from the computer consisted of amperehour capacity versus voltage plots and performance data such as ampere-hour efficiency and watt hour efficiency. Figures $4 \mathrm{~A}$ through 4C show discharge curves and Tables $\mathrm{V}, \mathrm{VI}$ and VII illustrate the performance characteristics.

Two of the EV type cells were discharged in a J227aD pulse discharge profile which approximates the duty cycle in an opcrating elert.ric vehicle. The discharge pattern is as follows :

$$
\begin{array}{ll}
\text { CHARGE : } & 40 \text { Amps for } 5 \text { hours, } 45 \text { minutes } \\
\text { DISCHARGE : } & 28 \text { seconds at } 200 \text { Amps } \\
& 50 \text { seconds at } 75 \text { Amps } \\
& 42 \text { seconds at open circuit }
\end{array}
$$

Figures 5 and 6 show the voltage versus time recorder plots obtained for cells EVl.0 and EVI3 respectively. The test. results demonstrate the capability of ERC designed $\mathrm{Ni}-\mathrm{Zn}$ cells to perform in an electric vehicle. Further, it substantiates our claims about the high current density capabilities of the non-sintered bonded $\mathrm{Ni}(\mathrm{OH})_{2}$ electrodes. The capacity decline observed is not due to the degradation of the positive and negative plates. Instead, it may be due to electrolyte loss at the electrode surface which leads to 
TABLE IV

BATTERY/MCNOBLOCK/:ELL TESTS

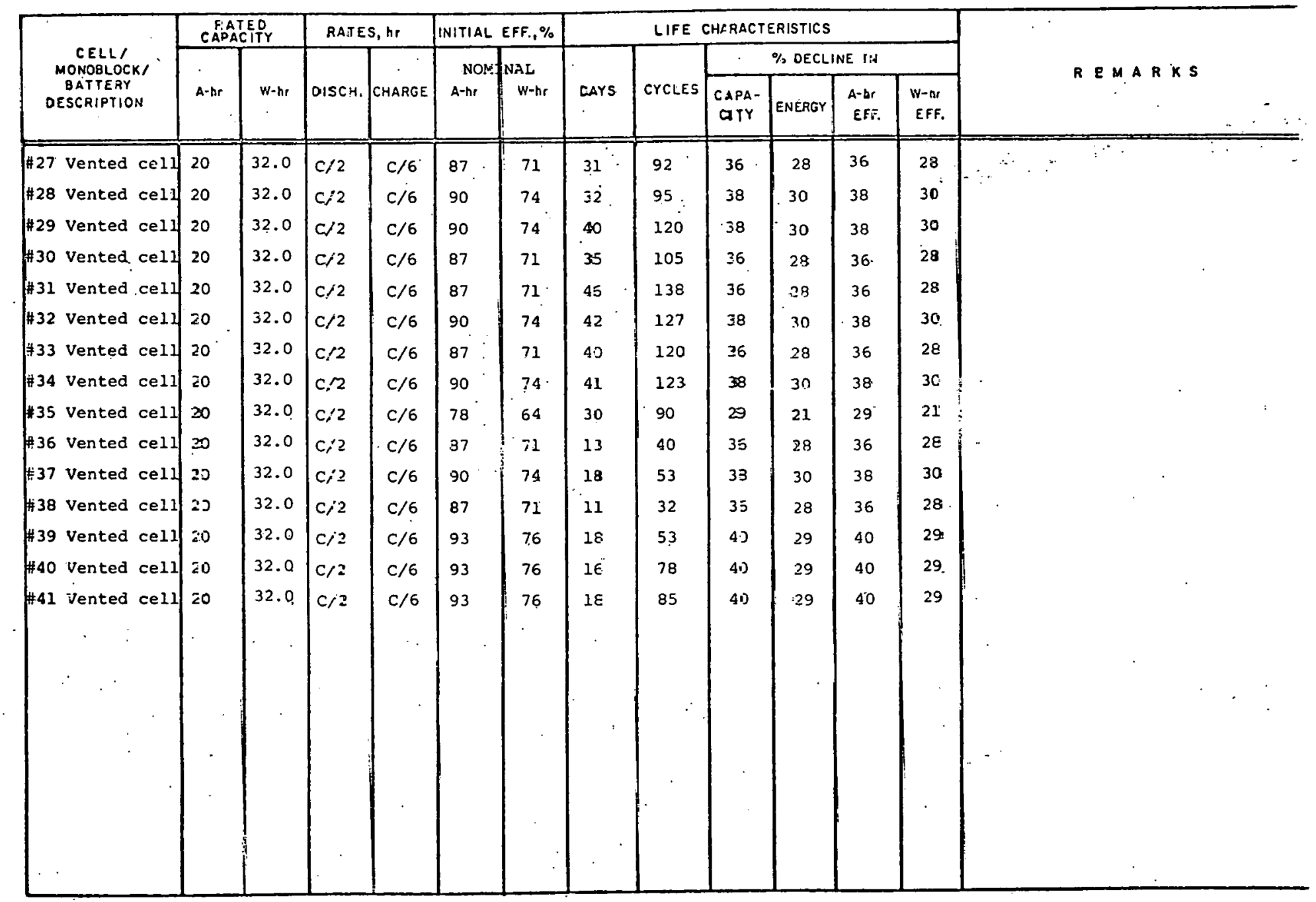




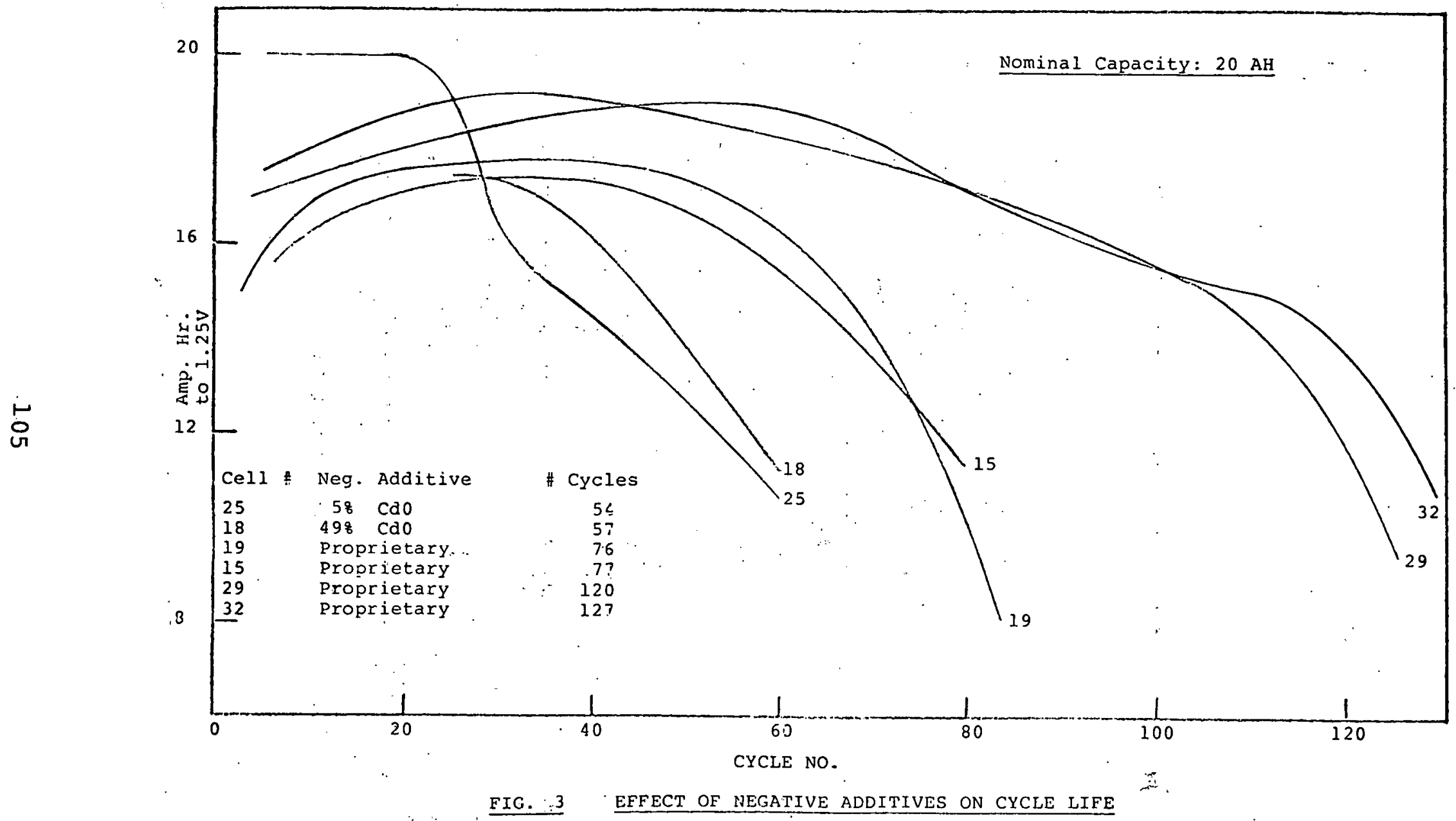




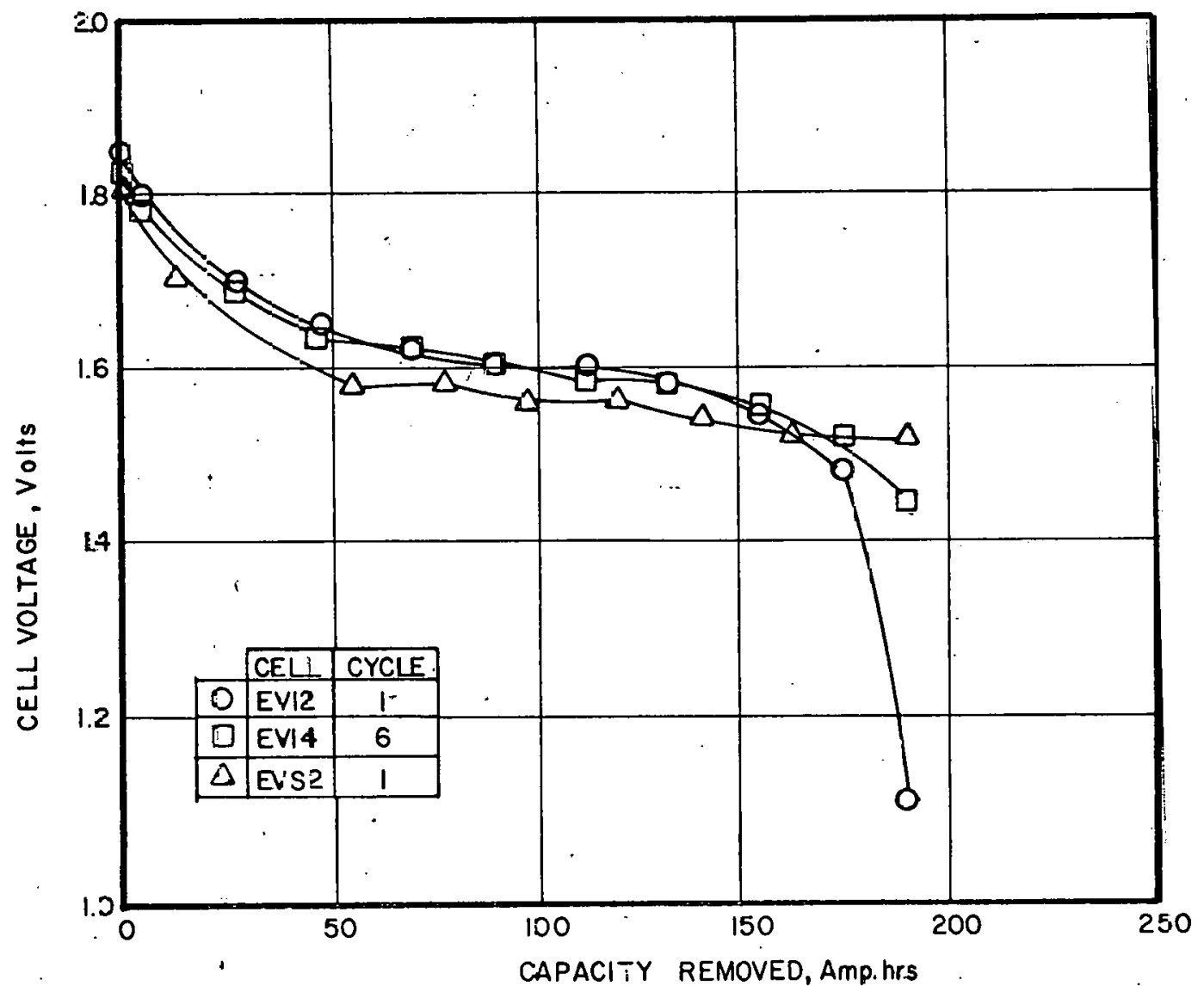

FÍGURE 4A. DISCHARGE PERFORMANCE, NI-Zn CELLS (FVl2, EVI4, EVS2) 


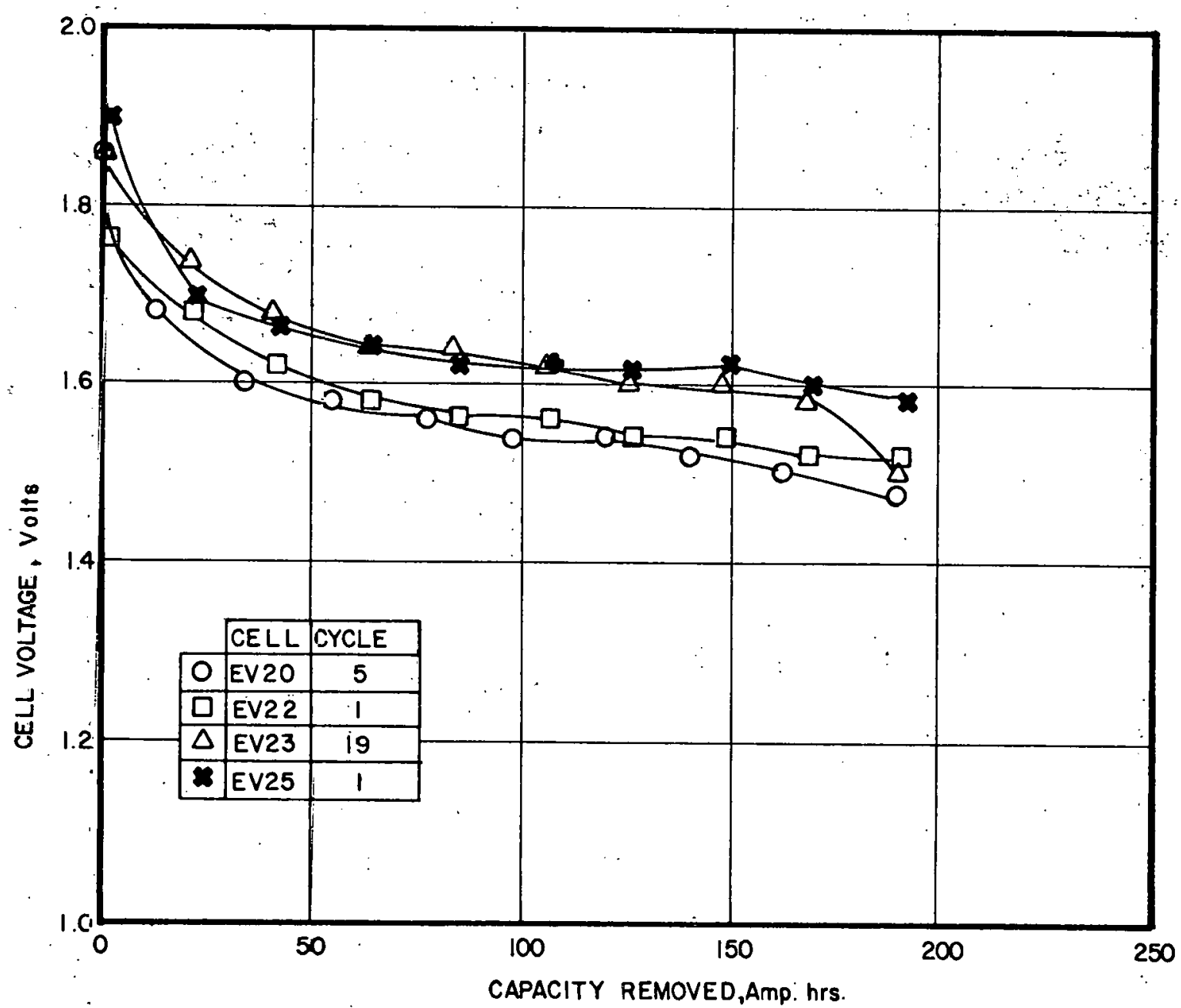

FIGURE 4B. DISCHARGE PERFORMANCE, Ni-Zn CELLS (EV20, EV22, EV23\& EV25) 


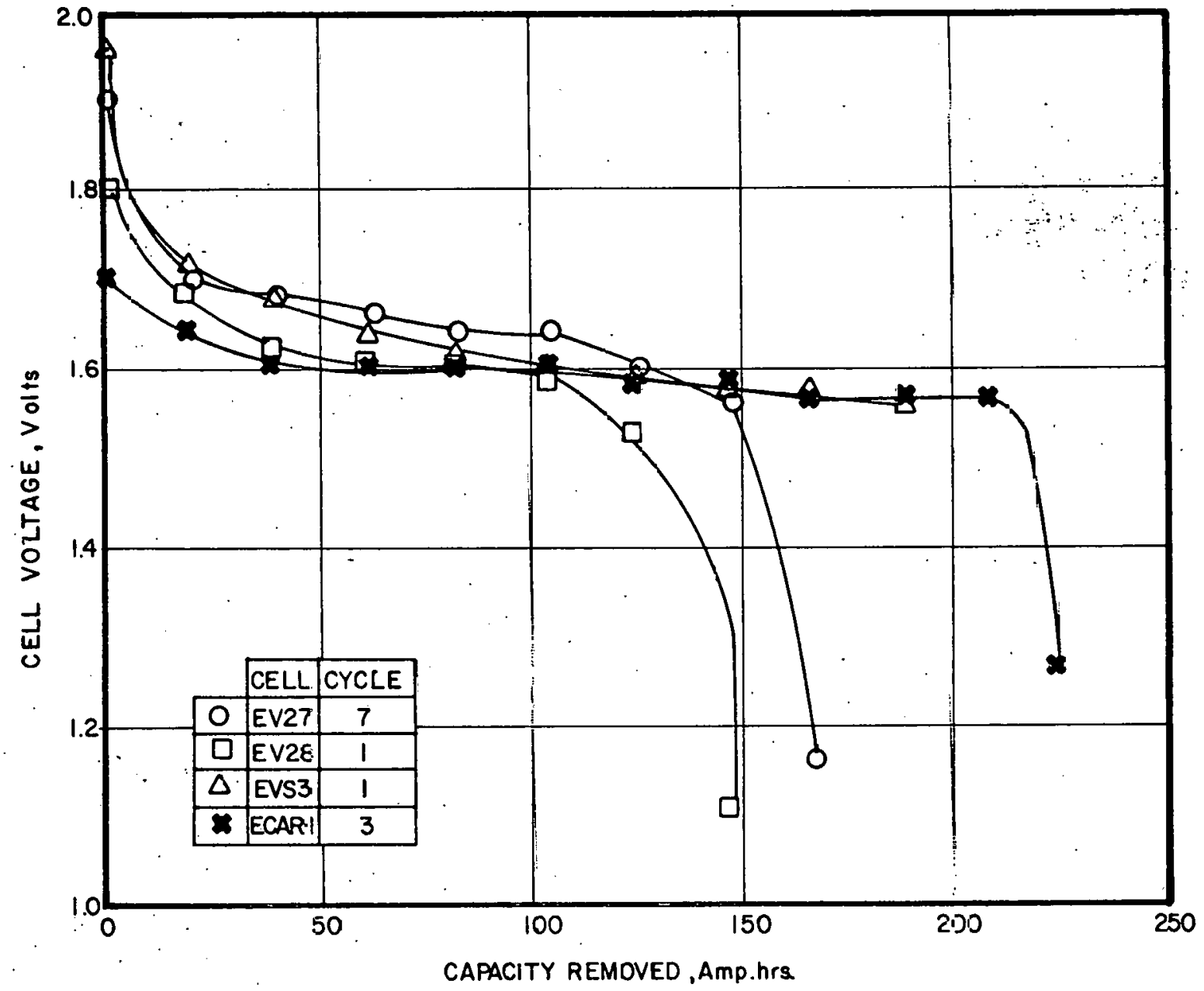

FICURE 4C. DISCHARGE PERFORMANCE, Ni-Zn CELLS (EV27; EV28, EVS3 \& ECAR-1) 


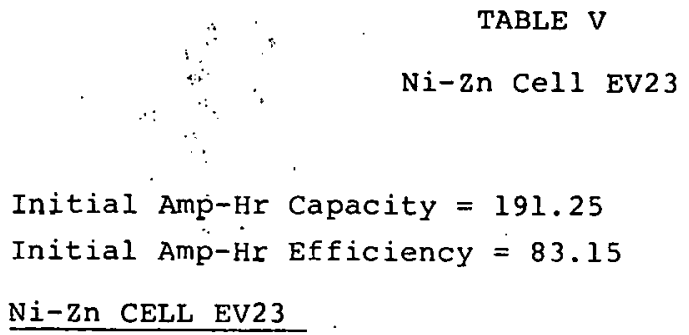

11.0

19.0

27.0

34.0

191.25

184.17

191.25

]. 91.25

183.98

0.0

3.7

0.0

0.0

3.8

Initial watt Hr. Efficiency $=72.55$

Cumulative percent decline in watt-hr efficiency in comparison to the watt-hr efficiency of the first given cycle.

\section{CYCLE}

5.0

11.0

19.0

27.0

34.0
CYCLE EFFICIENCY

73.59

70.41

72.78

71.17

68.54
PERCENT DECLINE

$$
\begin{array}{r}
-1.43 \\
2.95 \\
-0.31 \\
1.91 \\
5.54
\end{array}
$$




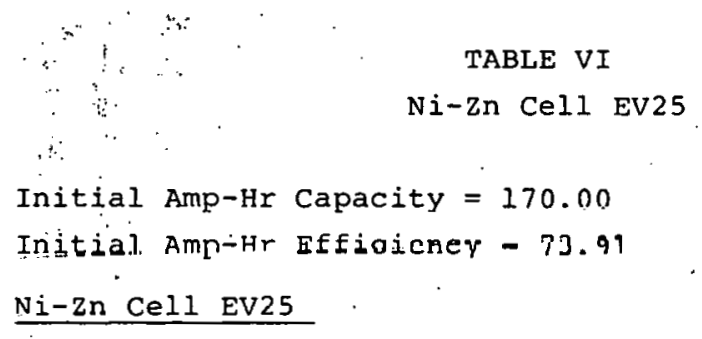

rumulativa pereenl. 1eullne in amp-hr and efficiency compared to first given cycle.

FIRST GIVEN CYCLE IS CYCLE NUMBER I.0

CYCLE

3. 0

5.0

9.0

14.0

16.0

20.0

24.0

27.0

30.0
AMP-HR. CAPACITY

$$
\begin{aligned}
& 165.22 \\
& 165.87 \\
& 191.25 \\
& 179.52 \\
& 177.67 \\
& 166.87 \\
& 164.97 \\
& 154.06 \\
& 161.15
\end{aligned}
$$

PERCENT DECLINE

$$
\begin{array}{r}
2.81 \\
2.43 \\
+\star * \pi \\
-5.60 \\
-4.51 \\
1.84 \\
2.96 \\
9.38 \\
5.21
\end{array}
$$

Initial Watt-Hr Fffiriency $=65.04$

Cunulative percent decline in watt-hr efficiency in comparison to the watt-hr efficiency of the first given cycle.

CYCLE

3.0
5.0
9.0
14.0
16.0
20.0
24.0
27.0
30.0

3.0

5.0

14.0

16.0

20.0

27.0

30.0
CYCLE EFF ICIENCY

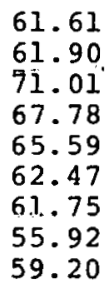

61.61

67.78

65.59

62.47

55.92

59.20
PERCENT DECLINE

$$
\begin{array}{r}
5.28 \\
1.04 \\
-9.10 \\
-4.21 \\
-0.84 \\
3.96 \\
5.06 \\
14.02 \\
8.98
\end{array}
$$


TABLE VII

$\because \quad \therefore \quad N i-Z n$ Cell EV22
$\because \quad \vdots$
Initial Amp-Hr Capacity $=191.25$
Initial Amp-Hr Efficiency $=83.15$
$\underline{\text { Ni-Zn Cell EV22 }}$

Cumulative percent decline in amp-hr capacity and efficiency compared to first given cycle.

FIRST GIVEN CYCLE IS CYCLE NUMBER 1.0

CYCLE

3.0

10.0

15.0

23.0

30.0

35.0

45. 0
AMP-HR. CAPACITY

191.25

191.25

$191.25^{\circ}$

191.25

160.13

121.55

70.83
PERCENT DECLINE

$$
\begin{gathered}
0.0 \\
0.0 \\
0.0 \\
0.0 \\
16.27 \\
36.44 \\
62.96
\end{gathered}
$$

Initial watt-Hr. Efficiency $=70.23$

Cumulative percent decline in watt-hr efficiency in comparison to the watt-hr efficiency of the first given cycle.

\section{CYCLE \\ CYCLE EFFICIENCY}

$3: 0$

10.0

15.0

23.0

30.0

35.0

45.0

$$
\begin{aligned}
& 70.36 \\
& 69.71 \\
& 70.21 \\
& 70.45 \\
& 57.03 \\
& 42.98 \\
& 24.68
\end{aligned}
$$

PERCENT DECLINE

$$
\begin{array}{r}
-0.18 \\
0.74 \\
0.04 \\
-0.32 \\
18.79 \\
38.80 \\
64.86
\end{array}
$$



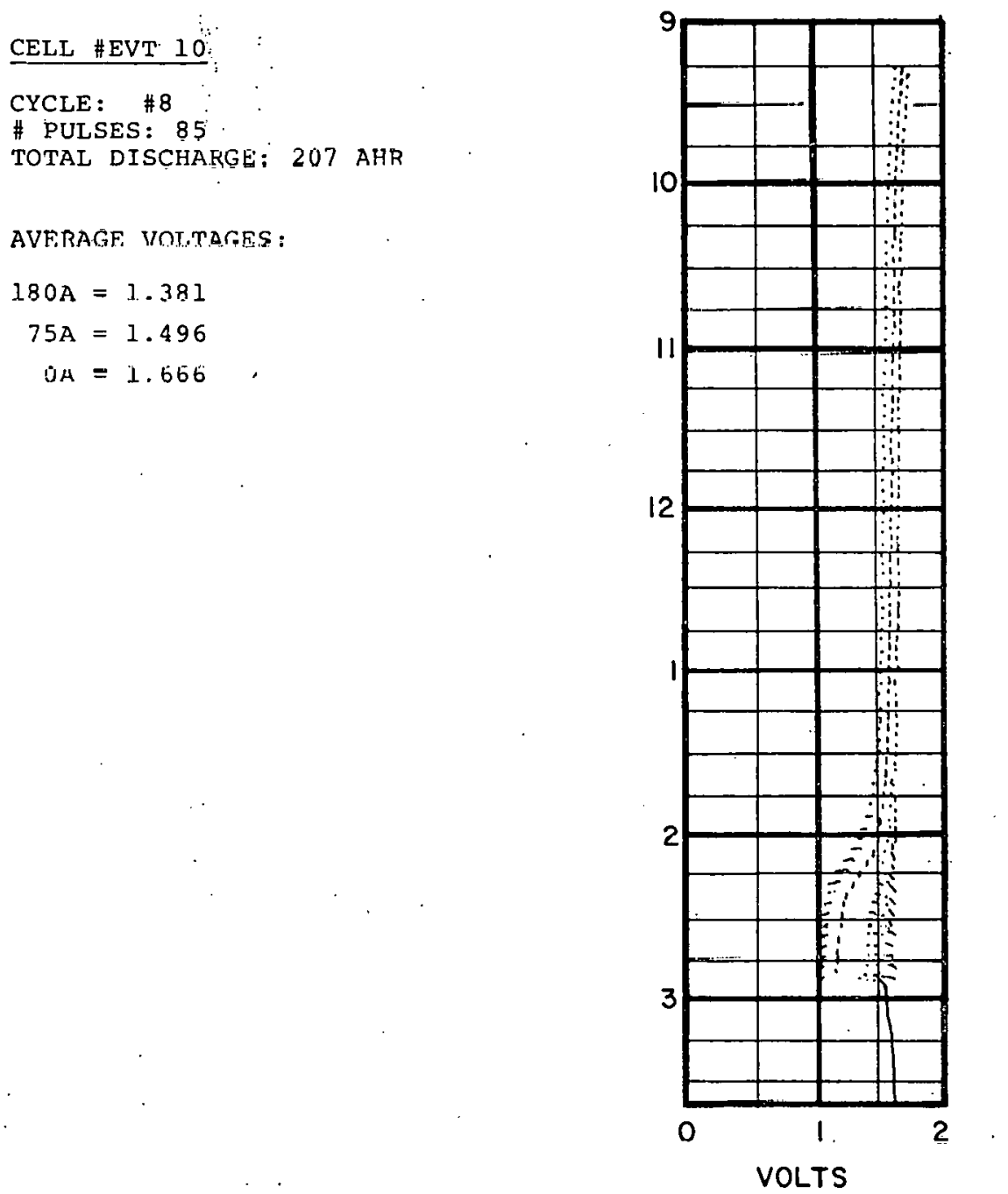

FIGURE 5. J227aD ELECTRIC PROFILE, CELL EVT 10 
CELL \#EVT 13

\# PULSES: 66

TOTAL DISCHARGE : 171 AHR

AVERAGE VOLTAGES :

$$
\begin{aligned}
200 \mathrm{~A} & =1.419 \\
75 \mathrm{~A} & =1.557 \\
0 \mathrm{~A} & =1.683
\end{aligned}
$$

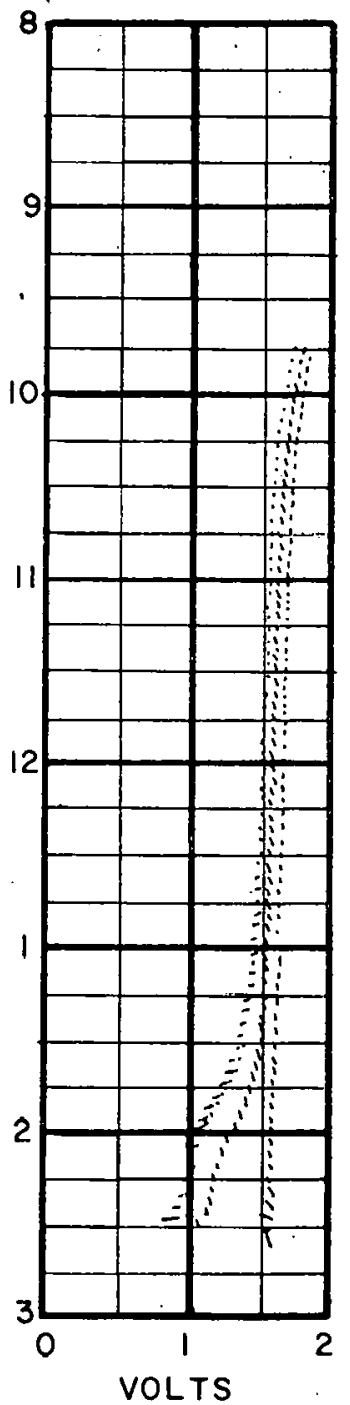

FLGUKL 6. J227AD ELECTRIC PROFILE, CELL EVT 13 
high temperatures inside the cell with subsequent oxidation of the separator. We are able to prove this fact by failure analysis.

The baseline design given in Table I does not incorporate any means to prevent electrolyte dryout. The situation may be improved by:

1. Using slightly thinner electrodes.

2. Adding reservoir type materials to the separator system.

3. Adding a vent mechanism to the cover assembly which reduces electrolyte loss during charging.

4. Using constant potential charging. 
3.1 Coulometric Technique

A major requirement for the successful application of $\mathrm{Ni}-\mathrm{Zn}$ cells for electric vehicle propulsion is a charge control procedure and a state of charge indicating system. Recognizing this, a coulometric type charge control was designed and fabricated. The following paragraphs describe the operating characteristics of the coulometer.

Construction

The coulometer uses the pressure variations in a nickelhydrogen cell to control charge. In other words, the $\mathrm{Ni}-\mathrm{H}_{2}$ cell acts as a control cell. A hermetically sealed nickel-hydrogen cell was assembled. The nickel hydroxide electrode in the control cell is of the same type as that used in the main Ni-zn cell.

A control circuit was designed for the coulometer. The main elements of the electronic circuitry are: 1) power supply, 2) shunt, 3) amplifier, 4) pressure switch and 5) pressure gauge. A block diagram of the coulometer circuit is given in Figure 7 .

Operation and Functional Features

Linearity: In order to test the circuitry the nickel-hydrogen cell was automatically charged and discharged by connecting it to ERC designed test equipment. During this experiment, the charging current and discharging current for the nickel-hydrogen cell were drawn through the shunt. First, the variation of voltage drop across the shunt with the current (charging or discharging) was determined. It was linear. Then the voltage drop across the shunt during a typical charging and discharging regime was monitored. The voltage drop remained constant as shown in Figure 8. The current through the coulometer cell was also monitored. As shown in Figure 8, a constant value for the current was obtained. During this experiment the current output from the automatic cycler was 4.0 amperes during charge and 10 amperes during discharge.

Typical Perfonmance: A 20 Ah nickel-zinc cell was assembled and used as the test vehicle to evaluate the coulometer. The nickel-zinc cell was connected to a DC power supply through a shunt. The coulometer was connected across the shunt as shown in Figure 7. The nickel-zinc cell was charged at 4.0 amperes. Under these conditions, the charging current for the nickel-hydrogen cell was 100 milliamperes. Nuring charge, the voltage of the $\mathrm{Ni}-\mathrm{Zn}$ cell and the pressure of the nickelhydrogen cell were monitored. The documented values for $\mathrm{Ni}_{2} \mathrm{H}_{2}$ pressure and Ni-Zn voltage are plotted in Figure 9. The pressure varied linearly with time. The Ni-Zn voltage reached a value of $2.0 \mathrm{~V}$ after 6 hours and 20 minutes. 
FIGURE 7: CUULUMEIEH CIRCUIT

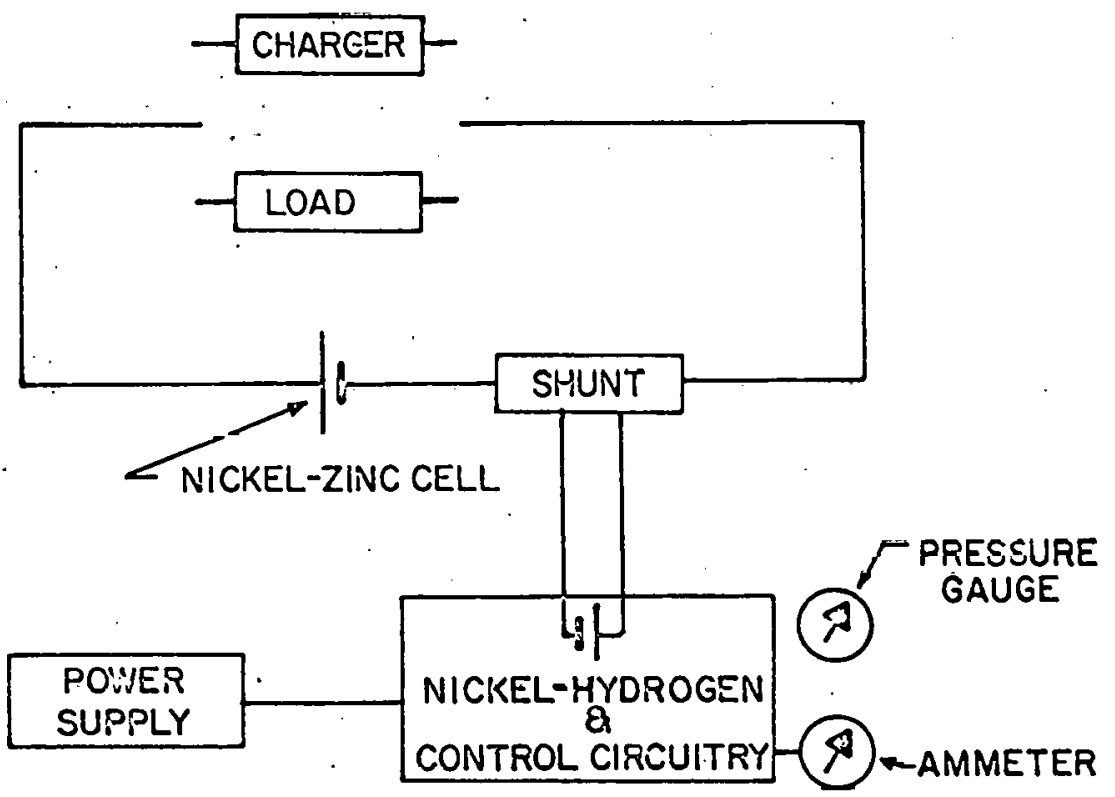


FIGURE 8: CONSTANCY OF VOLTAGE DROP AND CURRENT DURING CHARGE AND DISCHARGE

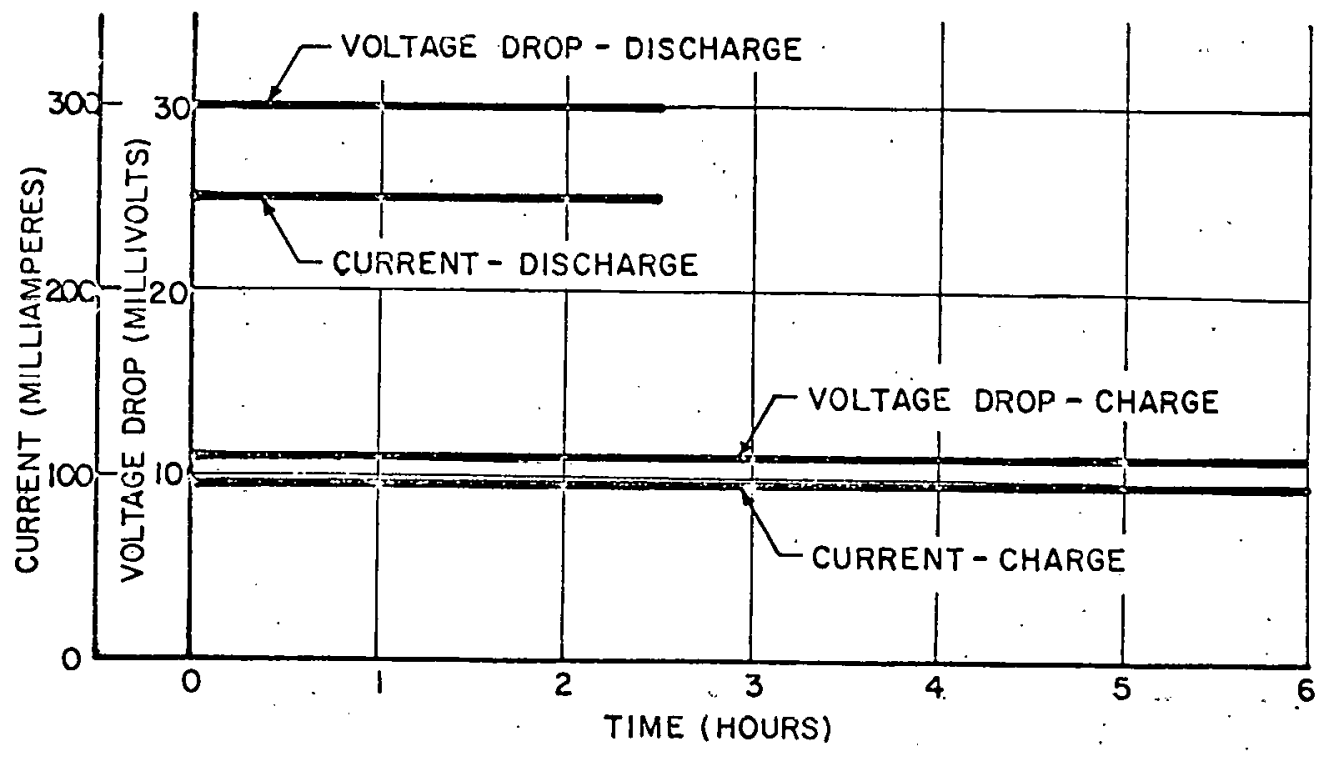


FIGURE 9 CHARACTERISTICS OF COULOMETRIC CHARGE CONTROL-CHARGE

A - VARIATION OF Ni - Zn VOLTAGE WITH TIME

B - VAR̆IAIIUN OF $\mathrm{Ni}-H_{2}$ PRESSURE W.ITH TIMF.

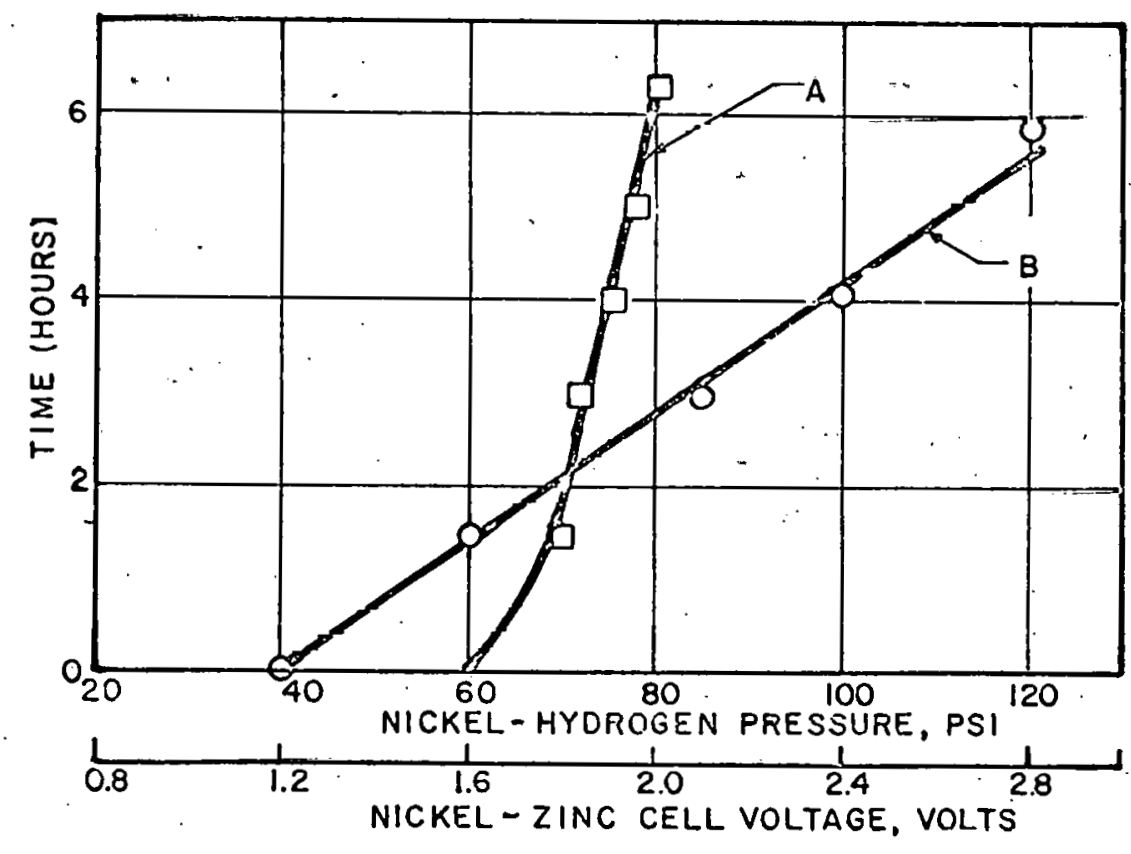


Then, the $\mathrm{Ni}-\mathrm{Zn}$ cell and the $\mathrm{Ni}-\mathrm{H}_{2}$ cell were discharged. The discharge current for the $\mathrm{Ni}-\mathrm{Zn}$ was 6 amperes and that for $\mathrm{Ni}-\mathrm{H}_{2}, 170$ milliamperes. Again the variations of $\mathrm{Ni}-\mathrm{H}_{2}$ pressure and $\mathrm{Ni}-\mathrm{Zn}$ voltage were monitored. The pressure varied linearly with time. The discharge characteristics are shown in Figure 10 .

The charging and discharging were repeated. Reproducible values for pressures were obtained at the end of charge and end of discharge. From the experimental data, it is evident that values for the pressure can be selected for the end of charge and end of discharge. Charging can be terminated by an automatic pressure switch as soon as a. preselected value for the pressure is reached.

\subsection{Constant Voltage Charging}

Since $\mathrm{H}_{2}$ evolution on $\mathrm{zinc}$ on overcharge is deleterious to the stability of the zinc, constant potential charging seems appropriate. An automatic cycler was assembled consisting of power supply, electronic relays and a timer. A voltage of 1.92 was selected for the controlled potential charging. This voltage is below the over-voltage at which $\mathrm{H}_{2}$ evolution occurs on $\mathrm{Zn}$. Figure 11 gives a typical charging curve. The charging current decays from 95 amperes at the beginning of charge to 10 amperes towards the end of charge. EVS2 was cycled using controlled potential charge and constant current discharge. The performance of EVS2 is given in

Figure 4A. 
FIGURE 10 CHARACTERISTICS OF COULOMETER DURING DISCHARGE $A=$ VARIATION OF NICKEL-ZINC VOLTAGE WITH TIME $B$ - VARIATION OF NICKEL - HYOREOGEN PRESSURE WITH TIME

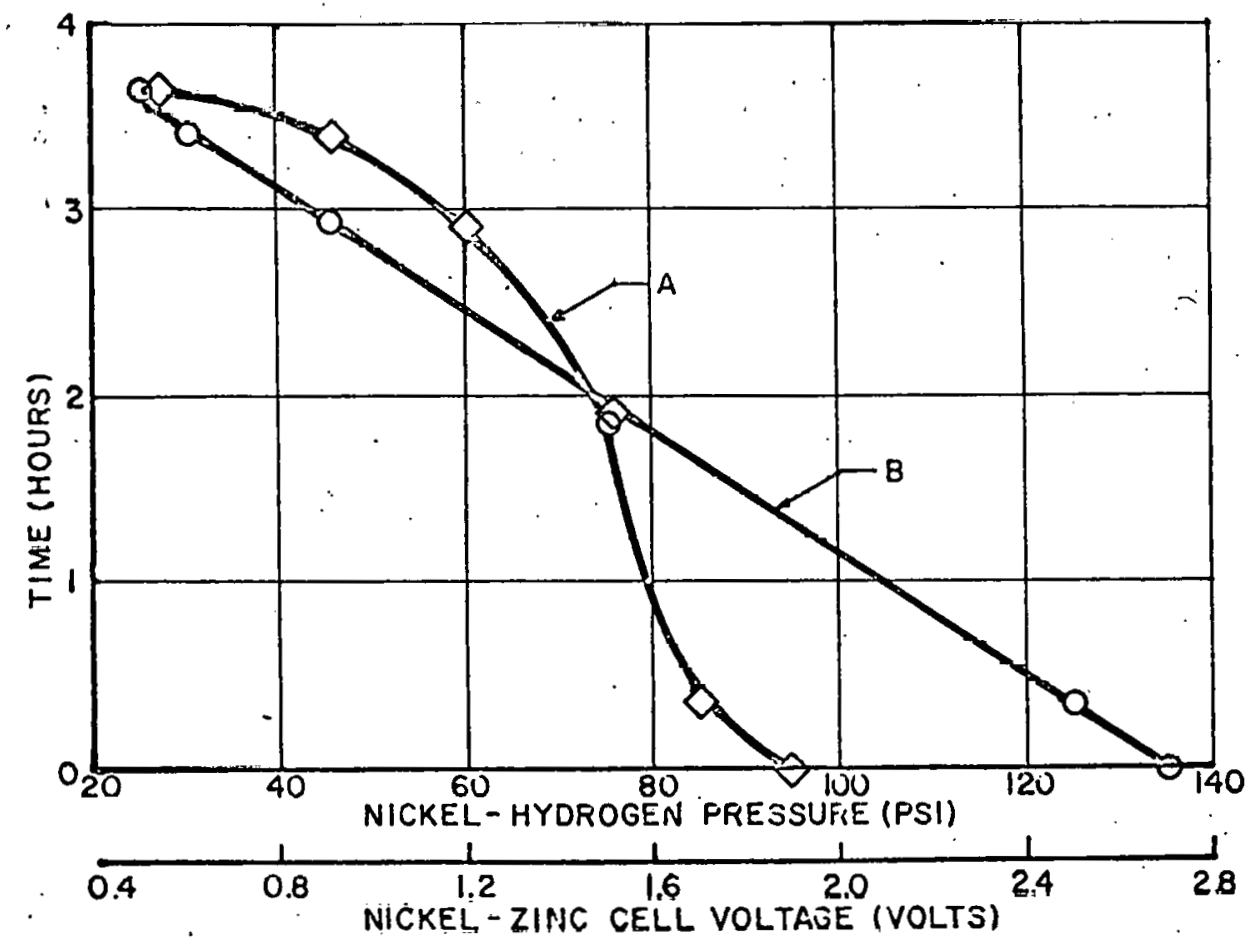


EVT S2

FIGURE II. CURRENT VARIATIONS DURING CONSTANT VOLTAGE CHARGING AT 1.92 VOLTS

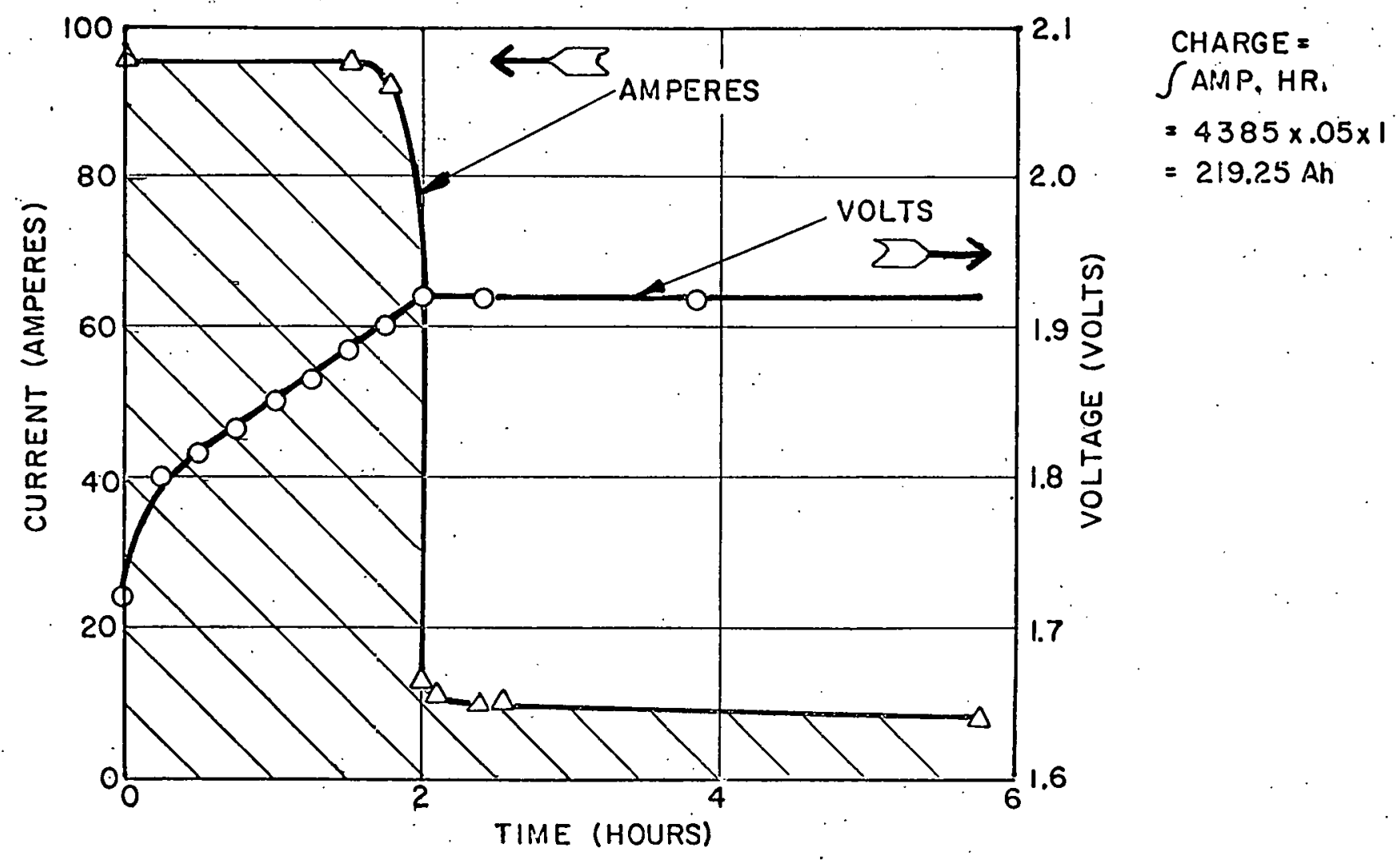




\subsection{DATA REDUCTION AND CELL MODELING}

All efforts during the period were directed toward the dual tasks of data reduction and mathematical modeling. Both tasks make use of the computer facilities at ERC.

The goal of the data reduction task is to furnish a program for the computer which will tabulate, graph and analyze the experimental data generated by cell testing. At the same time, these sets of raw data are entered on permanent files which are added to our growing bank of cell performance data.

The main data reduction program is complete and ready for regular use. This program performs the following functions: For each cycle:

1. Lists reference information

2. 'labulates three columns of data reflecting time elapsed, voltage, and amp-hr capacity removed

3. Plots a graph of voltage vs amp-hr capacity removed. This graphing routine is an upgraded version of our previously reported routine. All data points now appear on the graph with a maximum error of .01 volt.

For each cell (using data for all available cycles):

1. Calculates initial amp-hr capacity and efficiency

2. Tabulates percent decline in amp-hr capacity and efficiency (compared to first given cycle) for each cycle.

3. Calculates initial watt-hr efficiency

4. Tabulates percent decline in watt-hr efficiency (compared to first given cycle) for each cycle.

5. Plots a graph of the entire discharge performance history for the cell.' The graph plots total amp-hr capacity removed vs cycle number.

The goal of the modeling task is to produce a thermal model of battery electrodes which can be utilized to help improve cell performance and analyze cell failure. A computer program incorporating this mathematical model will show changing temperature distributions within the elestrode stack as a function of time. By changing the input parameters and studying the resulting thermal effects, the designer can use the program as an optimization tool to eliminate hot spots and "tailor" the temperature gradients to prevent failure and increase cycle lifc: 


\subsection{CONCLUSIONS}

It may be concluded from the preceding test data that:

1. Hg may be substituted with various proprietary additives.

2. The bonded-pressed $\mathrm{Ni}(\mathrm{OH})_{2}$ electrode performs as well as the conventional sintered $\mathrm{Ni}(\mathrm{OH})_{2}$ in $\mathrm{EV}$ type cells.

3. Constant potential charging seems quite promising as a simple means of controlling charge and overcharge.

4.: The coulometric method for charge control, in which the pressure of $\mathrm{Ni}-\mathrm{H}_{2}$ control cell is used as a signal to terminate charging is extremely reliable.

5. For EV type cells, electrolyte dry out, separator degradation and thermal gradients are more of a problem during the first 100 cycles of life. 


\section{Internal:}

\author{
J. J. Barghusen \\ D. Barney \\ C. Bean \\ E. C. Berrill \\ A. Brown \\ L. Burris \\ G. Chapman \\ A. A. Chilenskas \\ K. Choi \\ C. C. Christianson \\ G. Cook \\ D. Corp \\ S. A. Davis \\ W. Deluca \\ R. C. Elliott \\ P. R. Fields \\ F. Foster \\ D. Fredrickson
}

\author{
B. R. T. Frost \\ G. T. Garvey \\ E. C. Gay \\ J. Geller \\ $M$. Genge \\ F. Hornstra \\ C. C. Hsu \\ J. Klinger \\ V. Kremesec \\ A. B. Krisciunas \\ M. L. Kyle \\ W. W, I.ark. \\ T. Lee \\ M. Liti \\ R. Lout fy \\ J. Miller \\ W. Miller \\ P. A. Nelson
}

\section{External: .}

DOE-TIC, for distribution per UC-94ca (315)

Manager, Chicago Operations and Regional office, DOE Chief, Office of Patent Counsel, DOE-CORO

V. Hummel, DOE-CORO

President, Argonne Universities Association

Chemical Engineering Division Review Committee:

C. B. Alcock, U. Toronto

R. C. Axtmann, Princeton University

R. E. Balzhiser, Electric Power Research Institute

J. T. Banchero, Univ. of Notre Dame

T. Cole, Ford Mntor Cnrp.

P. W. Gilles, Univ. of Kansas

R. I. Newman, Allied Chemical Corp.

G. M. Rosenblatt, Pennsylvania State University

E. T. Ames, TRW Systems, Redondo Beach, CA

S. J. Angelovich, Mallory Battery Co., Tarrytown, NY

G. M. Arcand, Idaho State University, Pocatello, ID

R. Aronson, Electric Field Propulsion Corp., Troy, MI

G. N. Ault, NASA-Lewis. Research Center, Cleveland, $\mathrm{OH}$

A. Backerby, Powertrain, Inc., Salt Lake City, UT

W. Bales, Jet Industries, Inc., Austin, TX

K. F. Barber, DOE, Office of Transportation Programs, Washington, DC

T. Barber, Jet Propulsion Laboratory, Pasadena, CA

R. J. Barkley, Compass Industries, Inc., Hermosa Beàch, CA

T. M. Barlow, Lawrence Livermore Laboratory, Livermore, CA

D. Barron, Delco-Remy Div. GMC, Anderson, IN

R. Bassett, Sandia Labs, Albuquerque, NM 


\section{External:}

E. Baumann, LILCO, Mineola, NY

L. Belove, Marathon Battery Corp., Waco, TX

C. Berlsterling, C. Franklin Institute, Philadelphia, PA

D. N. Bennion, University of California, Berkeley, CA

C. Berger, Electrochemical \& Water Desa. Tech., Santa Anna, CA

L. Berkowitz, Esso Research \& Engineering Co., Linden, NJ

E. Berman, TRW Systems Group., McLean, VA

K. Blurton, Institute of Gas Technology, Chicago, IL

D. P. Boden, C\&D Batteries, Plymouth Meeting, PA

R. L. Boeger, Lectran, Huntington, PA

J. Bolger, University of California, Berkeley, CA

D. Borello, Die Mesh Corp., Pelham, NY

T. Boswell, Elgin National Watch Co., Elgin, IL

D. Bowman, United States Postal Service, Washington, DC

J. C. Boylan, Electric Dynamics Corp., Plainwell, MI

J. Brennand, General Research Corp., Santa Barbara, CA

A. F. Brewer, Malibu, CA

D. C. Briggs, Philco-Ford Corp., Palo Alto, CA

P. Bro, J. R. Mallory \& Co., Inc., Burlington, MA

E. P. Broglio, Eagle-Picher Industries, Joplin, MO

A. D. Brown, EVE Electric Motor Car, Inc., East Lansing, MI

P. J. Brown, DOE, Office of Transportation Programs, Washington, DC

R. Buchholz, Honeywell Corp., Minneapolis, MN

$T$. Burgess, Lucas Industries, N. A. Inc., Troy, MI

H. Burghart, Cleveland State University, Cleveland, $\mathrm{OH}$

D. Burns, Onan Corporation, Minneapolis, MN

B. W. Burrows, Gould Inc., Rolling Meadows, IL

E. Buzzelli, Westinghouse Electric Corp., Pittsburgh, PA

W. P. Cadogan, Emhart Corp., Hartford, CT

P. Campbel1, University of Southern California, Los Angeles, CA

R. T. Carpenter, Kimberly Clark Corp. Neenah, WI

T. V. Carvey, Hughes Aircraft Corp., Culver City, CA

R. Childs, Energy Research \& Development Corp., Olmsted Falls, OH

L. D. Christian, General Electric, Gainesville, FL

R. C. Chudecek, McGraw Edison Co., Bloomfield, NH

J. E. Clifford, Battelle Memorial Institute, Columbus, OH

P. D. Cole, Naval Ordinance Laboratory, Silver Springs, MD

J. G. Colin, Englehard Industries Inc., Edison, NJ

W. B. Collins, Martin Marietta Corp., Denver, Co

J. E. Cooper, Aero Propulsion Laboratory, Wright-Patterson AFB, OH

R. E. Corbett, Lockhead Missiles \& Space Co., Sunnyvale, CA

J. F. Corcoran, Wolverine Diesel Power Co., Traverse City, MI

K. E. Cox, University of New Mexico, Albuquerque, NM

W. W. Craig, Edward Harding and Co., Chicago, IL

D. Crane, United States Postal Service, Washington, DC

H. H. Crist, AM General Corp., Wayne, MI

D. Davis, Lawrence Livermore Laboratory, Livermore, CA

P. Davis, DOE, Office of Transportation Programs, Washington, DC

R. J. Dawson, ESB Inc., Madison, WI

N. A. Demerdash, Virginia Polytechnic Institute, Blacksburg, VA

G. A. DiBari, INCO, Sterling Forest Suffern, NY

W. J. Dippold, DOE, Office of Transportation Programs, Washington, DC 
T. P. Dirske, Calvin College, Grand Rapids, MI

D. Dow, Consulting Engineer, Detroit, MI

E. F. Echolds, AiResearch Manufacturing Co., Torrance, CA

D. B. Eisenhaure, Charles Stark Draper Lab Inc., Cambridge, MA

M. W. Ellison, Hughes Aircraft Corp., E1 Segundo, CA

B. Enserik, Dynamic Science, Phoenix, AZ

R. E. Evans, John Hopkins University, Silver Springs, MD

A. Ewing, DOE, Office of Transportation Programs, Washington, DC

F. Fedor, Bell Laboratories, Murray Hill, NJ

W. H. Fengler, Meteor Research Limited, Roseville, MI

R. Ferraro, Electric Power Research Institute, Palo Alto, CA

A. Fleischer, Orange, NJ

R. F. Fogle, North American Rockwe11, Anaheim, CA

R. T. Foley, American University, Washington, DC

$\mathrm{J}$. S. Fordyce, NASA-Lewis Research Center, Cleveland, $\mathrm{OH}$

D. Friedman, Minicars, Inc., Goleta, CA

$C$. Gelb, Advanced Ground Systems, Long Beach, CA

S. Geppert, Eaton Corporation, Southfield, MI

L. J. Gerlach, United States Postal Service, Rockville, MD

J. A. Gilchrist, Chloride America, 'I'ampa, FL

W. Gillespie, Structural Plastics Inc., Tulsa, OK

C. Glassman, Transportation Research Center, East Liberty, OH

M. Globerman, GSA, Washington, DC

W. Goldman, Electric Vehicle Engineering, Lexington, MA

G. Goodman, Globe-Union Inc., Milwaukee, WI

R. E. Goodson, Purdue University, W. Lafayette, IN

J. Gould, Unique Mobility Inc., Englewood, CO

C. B. Graff, NASA-George C. Marshall Space Flight Center, Huntsville, AL

H. Grepke, TurElec Inc., Bradenton, FL

R. Guess, General Electric Research Lab, Schenectady, NY

K. G. Gunther, General Motors Research Labs, Warren, MI

M. Hadden, Billings Energy Corp. Provo, UT

G. Hagey, DOE, Division of Technology Overview, Washington, DC

G. Halpert, NASA-Goddard Space Flight Center, Greenbelt, MD

H. Hamilton, University of Pittsburgh, Pittsburgh, PA

R. Hamilton, Institute for Defense Analysis, Arlington, VA

B. Hamling, Zircar, Florida, NY

D. Hanify, Fiat, Chicago, IL

K. L. Hanson, General Electric Co., Philadelphia, PA

W. Harhay, Electric Vehicle Associates, Cleveland, $\mathrm{OH}$

J. H. Harrison, Naval Ship R\&D Center, Anapolis, MD

G. Hartman, ESB Incorporated, Yardley, PA

J. Hartman, General Motors Research Labs, Warren, MI

E. A. Heintz, Airco Speer Carbon Graphite, Niagara Falls, NY

R. Heppenstall, Penn Jersey Suburu Inc., Pennsauken, NJ

V. Hlavin, NASA-Lewis Research Center, Cleveland, $\mathrm{OH}$

G. Hobbib, ESB Inc., Cleveland, OH

R. Hoenburg, Mechanical Technology Inc., Latham, NY

N. W. Hop, AiResearch Mfg. Co., Phoenix, AZ

$R$. Hudson, Eagle-Picher Industries, Joplin, MO

H. L. Hughes, Oklahoma State University, Stillwater, OK

$\mathrm{J}$. R. Hunt, International Nickel Co., Washington, DC

H. R. Ivey, Wood-Ivey Systems Corp., Winterpark, FL

G. H. Jantz, Rensselaer Polytechnic Institute, Troy, MI 
F. Johnson, Department of Industry, Trade and Commerce, Ottawa, Canada

L. Jok1, MERADCOM, Fort Belvoir, VA

W. J. Jones, Westinghouse Electric Corp., Pittstburgh, PA

D. Kane, National Motors Corp., Lancaster, PA

E. Kanter, Gulton Battery Corp., Metuchen, NJ

N. Kaplan, Harry Diamond Laboratories, Washington, DC

R. Kaylor, Kaylor Energy Products, Menlo Park, CA

J. A. Kerrella, Delco-Remy Division/GMC, Anderson, IN

R. A. Keyes, Robert A. Keyes Associates, Martinsville, IN

R. S. Kirk, DOE, Office of Transportation Programs, Washington, DC

G. B. Kliman, General Electric Co., Schenectady, NY

G. B. Klinean, General Electric Co., Schenectady, NY

R. A. Knight, AMF Inc., Stanford, CT

J. G. Krisilas, Aerospace Corporation, E1 Segundo, CA

L. Kulin, Whirlpool Corp. Benton Harbor, MI

H. Lauve, Electric Auto Corporation, Troy, MI

I. J. Levine, Con Edison, New York, NY

A. Long, Zeonics Corp., Fairfax, VA

M. Lugash, Maxon Industries, Huntington Park, CA

J. MacDouga 11, AT\&T, Basking Ridge, NJ

J. Mader, Electric Power Research Institute, Palo Alto, CA

J. Maisel, Cleveland State University, Cleveland, $O H$

V. Manson, National Aeronautics and Space Adm., Washington, DC

T. W. Martin, United State Postal Service, San Bruno, CA

A. Master, Packaged Promotions Inc., Chicago, IL

C. E. May, NASA-Lewis Research Center, Cleveland, $\mathrm{OH}$

E. Meeks, Derl Manufacturing Co., Compton, CA

P. Mighdoll, Booz-Allen \& Hamilton, Cleveland, $\mathrm{OH}$

R. P. Mikkelson, General Dynamics, San Diego, CA

D. G. Miley, U.S. Naval Ammunition Depot, Crane, IN

H. Miller, Department of Transportation, Cambridge, MA

D. K. Miner, Copper Development Associates, Birmingham, MI

L. J. Minnich, G\&W H. Corson, Inc., Plymouth Meeting, PA

F. J. Mollura, Rome Air Development Center, Griffiss AFB, NY

F. Moore, DOE, Energy Storage Systems, Washington, DC

A. Moss, Leesona Moos Laboratories, Warwick, RI

R. Mueller, University of California, Berkeley, CA

J. H. Muir, Dimension V Inc.; Tndialantic, FL.

J. P. Mulling, National Aerautics and Space Adm., Washington, DC

G. Murphy, Northwestern University, Evanston, IL

N. T. Musial, NASA-Lewis Research Center, Cleveland, $\mathrm{OH}$

J. McCallum, Invent ion Talents, Inc., Columbus, $\mathrm{OH}$

B. McCormick, Los Alamos Scientific Labs, Los Alamos, NM

R. McCoy, B\&Z Electric Car, Long Beach, CA

R. McKee, McKee Enginecring Corp., Palatine, IL

$\mathrm{J}$. Mckeown, DOE, Office of Program Administration, Washington, DC

W. J. Nagle, NASA-Lewis Research Center, Cleveland, $\mathrm{OH}$

H. V. Nadham, Bogue Batteries, El Segundo, CA

L. Nalley, Creative Research Co., Roebuck, SC

J. S. Newton, Newton Engineering Co., Glen Ellyn, IL

M. M. Nickolson, Atomics Internat ional Division, Canoga Park, CA

J. Norberg, ESB Inc., Philadelphia, PA

L. Omohundro, Kingery Research \& Development, Wake Forest, MC

B. N. Otzinger, North American Aviation, Downey, CA 
J. E. Oxley, Gould Inc., Rolling Meadows, IL

E. Papandreas, REI, Lake Worth, FL

J. S. Parkinson, Johns-Manville R\&D Center, Manville, NJ

E. Patagalia, GSA, Washington, DC

C. Pax, DOE, Office of Transportation Programs, Washington, DC

G. F. Pezdirtz, DOE, Energy Storage Systems, Washington, DC

A. G. Plunckett, General Electric R\&D Center, Schenectady, NY

M. Pocabello, Triad Services, Dearborn, MI

V. J. Puglisi, Yardney Electric Corp., Pawcatuck, CT

J. Purce11, Chicago Operations Office, Argonne, IL

E. Ramirez, Amectran, Dallas, TX

E. Raskin, USAF Cambridge Research Laboratory, Bedford, MA

A. D. Raynard, AiResearch Manufacturing Co., Torrance, CA

H. L. Recht, Atomics Internations Division, Canoga Park, CA

C. Ridgway, Walt Disney World Co., Lake Buena Vista, FL

E. Rizkalla, DOE, Washington, DC

S. J. Romer, Solargen Electronics Ltd., New York, NY

L. Rosenblum, NASA-Lewis Research Center, Cleveland, $\mathrm{OH}$

N. Rosenburg, Department of Transportation, Cambridge, MA

R. Kosey, Westinghouse Electric Corp., Pittsburgh, PA

J. W. Ross, Texas Instruments Inc., Att leboro, MA

J. Rossmon, Cornell University, Ithaca, NY

G. Rowland, General Electric, Schenectady, NY

J. Rubenzer, NASA-Ames Research Center, Moffett Field, CA

P. H. Rubie, Electric Passenger Cars Inc., San Diego, CA

J. Salihi, Ot is Elevator, Co., Parsipanny, NJ

I. O. Salyer, Monsanto Research Corp., Dayton, $\mathrm{OH}$

G. Scharback, American Motors Corp., Wayne, MI

D. F. Schmidt, General Electric Co., Washington, DC

R. Schmidt, Volkswagon of America Inc., Englewood Ciliffs, NJ

L. W. Schopen, NASA-Lewis Research Center, Cleveland, $\mathrm{OH}$

S. Schuldiner, Naval Research Laboratory, Washington, DC

R. Schwartz, ASL Enginering, Goleta, CA

W. R. Scott, TRW Systems Inc., Redondo Beach, CA

H. Seigel, South Coast Technology Inc., Santa Barbara, CA

H. Seiger, Waterford, CT

J. Seliber, Fluid Drive Engineering Co., Wilmette, IL

E. Seo, Gates Energy Products. Denver, CO

L. Shahnasarian, Elcar Corp., Elkhart, IN

R. C. Shair, Hollywood, FL

H. Shalit, ARCO Chemical Corp., Glendoden, PA

D. W. Sheibley, NASA-Lewis Research Center, Cleveland, $\mathrm{OH}$

H. P. Silverman, TRW Systems, Redondo Beach, CA

J. Smits, Nevada Operations Office, Las Vegas, NV

I. J. Soloman, IIT Research Institute, Chicago, IL

R. L. Strombotne, Transportation Systems Center, Cambridge, MA

F. Tepper, Catalyst Research Corp., Baltimore, MD

C. E. Thomas, Chrysler Corp., New Orleans, LA

G. M. Thur, DOE, Office of Transportation Programs, Washington, DC

L. Topper, National Science Foundation, Washington, DC

W. Toth, Society of Automotive Engineers, Inc., Warrendale, PA

I. Trachtenberg, Texas Instruments, Dallas, TX

G. H. Turney, Western Research Industries, Las Vegas, NV

E. A. Ulrich, Creative Automotive Research, Whittier, CA 
R. L: Ulrich, GSA, Washington, DC

T. Ulrich, McGraw-Edison Co., Bloomfield, NJ

G. Underhill, A. D. Little, Cambridge, MA

C. J. Venuto, C\&D Batteries, Plymouth Meet ing, PA

E. H. Wakefield, Linear Alpha Inc., Evanston, IL

C. H. Waterman, C. H. Waterman Industries, Althol, MA

E. Y. Weissman, GASF Wynadotte Corp., Wynadotte, MI

I. Wender, Bureau of Mines, Pittsburgh, PA

R. L. Wentworth, Dynatech Corp., Cambridge, MA

R. D. Wherle, Sandia Labs, Albuquerque, NM

M. E. Wilke, Burgess Battery Company., Freeport, IL

R. Wilks, Lavelle Aircraft Co., Newton, PA

C. F. Williams, Teledyne Isotopes, Timonium, MD

J. M. Williams, E. I. DuPont DeNemours \& Co., Wilmington, DE

E. Willihnganz, C\&D Batteries, Plymouth Meeting, PA

J. F. Wing, Booz-Allen \& Hamilton Inc., Bethesda, MD

K. Winters, Chrysler Corp., New Orleans, LA

T. J. Wissing, Eaton Corp., Southfield, MI

J. Wooldridge, Boeing Corp., Seattle, WA

V. Wouk, Petro-Electric Motor Ltd., New York, NY

R. A. Wynveen, Life Systems Inc., Cleveland, $O H$

L. Yanni, Booz-Allen \& Hamilton Inc., Bethesda, MD

H. Yoder, Battronic Truck Corp., Boyertown, PA

J. E. Zanks, NASA-Langley Research Center, Hampton, VA

P. Zanoi, Boulder, CO

M. Zlotnick, DOE, Conservation Research \& Technology, Washington, DC 